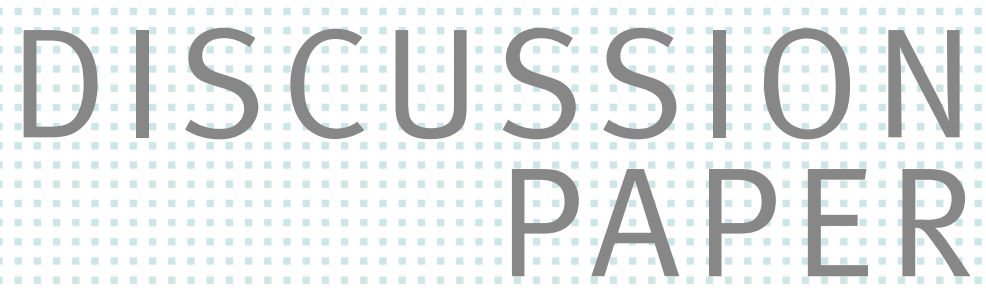

// MATTHIAS KRAPF, ANJA ROTH, AND MICHAELA SLOTWINSKI

The Effect of Childcare on Parental Earnings Trajectories 


\title{
The effect of childcare on parental earnings trajectories
}

\author{
Matthias Krapf ${ }^{\dagger}$, Anja Roth ${ }^{\ddagger}$, and Michaela Slotwinski ${ }^{\S}$
}

August 22, 2020

\begin{abstract}
We study the effect of childcare availability on child penalties. Using Swiss administrative data, we exploit the staggered opening of childcare facilities across municipalities in the canton of Bern. We find that the presence of childcare facilities in the year of birth of the first child reduces the child penalty. The availability of childcare increases maternal earnings and decreases the compensating increase in fathers' earnings in households with below median earnings, but not in households with above median earnings. Although childcare affects relative earnings contributions within the household, there is no effect on total household earnings.
\end{abstract}

Keywords: Child penalty, childcare, parental employment, gender wage gap JEL classifications: D1, J00, J13, J16, H31

\footnotetext{
†University of Lausanne, Department of Economics, Faculty of Business and Economics (HEC Lausanne), 1015 Lausanne, Switzerland. Phone: +41 (0)61 20758 29, email: matthias.krapf@unil.ch.

${ }^{\ddagger}$ University of Basel, Faculty of Business and Economics, Peter Merian-Weg 6, 4002 Basel, Switzerland. Email: anja.roth@unibas.ch.

$\S$ University of Basel, Faculty of Business and Economics, Peter Merian-Weg 6, 4002 Basel, Switzerland. ZEW - Centre for European Economic Research, L7,1, 68161 Mannheim, Germany.

Phone: +41 (0)61 20733 75, email: michaela.slotwinski@unibas.ch.

Michaela Slotwinski gratefully acknowledges financial support from the NCCR on the move financed by the Swiss National Science Foundation. We are grateful to Esther Mirjam Girsberger, Kurt Schmidheiny, and Conny Wunsch for helpful comments. Special thanks go to Lisa Triolo for her excellent research assistance.
} 


\section{Introduction}

The narrowing of the gender gap in earnings has been one of the major advances in society over the past decades. Goldin (2006) pointedly describes how over the past century, women have evolved from passive workers, whose life cycle patterns were largely determined by economic necessity and marriage, to decision makers, whose "occupation and employment define [their] societal worth." Women's higher investments in their education and careers reflect increased intrinsic motivation to succeed in the labor market.

Despite the advances in women's educational attainment and labor market attachment, the gender earnings gap still widens substantially with age, especially in the 15 to 20 years after leaving school (Goldin et al., 2017) and the birth of a first child still heavily affects women's life cycle earnings patterns. ${ }^{1}$ Goldin and Mitchell (2017) reason that the drop in women's earnings observed during their early to mid 30s has become more apparent precisely because of the increase in employment at younger ages.

Recent literature argues that the divergence of female and male earnings following the birth of their first child, also referred to as the "child penalty", nowadays accounts for most of the gender inequality in earnings. Kleven et al. (2019a) find that in Denmark, earnings of mothers and fathers diverge by 20 percent in the long run. ${ }^{2}$ The resulting differential impact of childbirth on lifetime earnings might adversely affect women in their pension payments, savings, economic self-sufficiency, and their power in household bargaining compared to men (Goldin et al., 2017). This suggests that addressing the child penalty is first order when it comes to reducing gender inequality in earnings and its consequences. It is therefore crucial to understand whether the differential is a deliberate preference-based choice or whether it is brought about by a lack of institutions hindering women, who would otherwise prefer to remain employed, to stay attached to the labor market. A lack of affordable and available formal childcare arrangements is seen as one major obstacle to the labor market attachment of mothers (see, e.g., Kleven et al., 2019a; Olivetti and Petrongolo, 2017). ${ }^{3}$

In this paper, we contribute to a better understanding of the child penalty by studying whether childcare policies attenuate the drop in labor earnings, henceforth referred to as earnings, women experience after the birth of their first child. We propose that the institutional environment when the first child is born is a major determinant of female earnings and employment patterns in subsequent years.

\footnotetext{
${ }^{1}$ See, e.g. Goldin et al. (2017) or Goldin (2014) for more detailed discussions of the persisting gender earnings gap and how it is affected by children.

${ }^{2}$ Kleven et al. (2019b) extend the analysis in Kleven et al. (2019a) to six countries with varying policies and norms, Austria, Denmark, Germany, Sweden, the United Kingdom, and the United States. They show that the gender gap in earnings 10 years after the birth of the first child varies substantially between countries, ranging from 20 percent in Denmark to 60 percent in Germany.

${ }^{3}$ Kleven et al. (2019a) and Olivetti and Petrongolo (2017), for example, argue that childcare is one of the main reasons for the comparatively high labor market attachment of mothers in Scandinavian countries.
} 
In order to establish the effect of childcare availability on the child penalty, we introduce institutions into the event study framework. Switzerland is well-suited to study the impact of childcare on the earnings penalty. Childcare facilities have only become more prevalent in the past 20 years. The combination of administrative data on individuals' earnings and the staggered opening of childcare facilities across municipalities in the canton of Bern allows us to compare child penalties of parents in municipalities after the introduction of childcare facilities to child penalties of parents in the same municipalities before the introduction of childcare facilities in an otherwise homogeneous institutional setting. We find a female child penalty (in earnings) of about 70 percent, which is partly driven by a participation reduction of about 20 percent six years after the birth of the first child. The documented earnings penalty is comparable to the one found for Germany (for numbers on Germany and five other countries, see Kleven et al., 2019b). However, while the reduction in female participation rates in Germany is a major factor in explaining the earnings gap after the birth of a first child, in Switzerland the intensive margin, i.e., the decision how much to work, seems especially relevant.

We find that the presence of a childcare facility in the municipality of residence at the time of birth of a first child decreases the total child penalty by 8.2 percentage points (10.4 percent) from 79 percent to 70.8 percent. More than 50 percent of this effect are due to a reduction of the female child penalty by 4.5 percentage points ( 6.3 percent) from 71.4 percent to 66.9 percent. Childcare reduces the female child penalty in households with below-median household earnings by 11.2 percentage points, which fully accounts for the overall effect among women. We do not observe any statistically significant response among women in households with above median earnings. ${ }^{4}$

A reduction in the increase in male earnings in the presence of childcare explains the other half of the reduction in the child penalty. Without childcare, we find a positive long-run response of male earnings to parenthood, which also contributes to the child penalty. We find a substantial impact of parenthood for men in households with below median earnings, whose earnings increase by about 20 percent. Childcare reduces this increase by 8.4 percentage points. This is consistent with the idea that men have to make up for lost earnings of their partner. ${ }^{5}$

The increase in female earnings and the decrease in male earnings cancel each other out. The availability of childcare thus has no effect on total household earnings, but increases the relative earning contribution by women by about 2.7 percentage points.

Furthermore, we are able to empirically study how the availability of childcare and financial support for childcare costs interact with one another because some municipalities in the canton of Bern introduce subsidies sometime after the opening of a childcare facility. We find that the main part of the overall effect on the female child penalty is most likely

\footnotetext{
${ }^{4}$ We define households according to their pre-child earnings. Also, note that we define household earnings as the combined earnings of both parents irrespective of whether they actually form a household.

${ }^{5}$ Note that part of the increase in male earnings is mechanical as it includes child benefits, which are declared as part of their earnings.
} 
driven by subsidized childcare. There is only a slight effect of childcare without subsidies in the three years following the birth of the first child with no longer term effect. Subsidized childcare, however, reduces the child penalty by about 10 percent.

Our results render valuable insights to assessing the effectiveness of formal childcare as a policy instrument. Generally, policy makers tend to provide childcare with two goals in mind: First, they want to increase women's labor market attachment, thus increasing their economic independence and reducing the gender earnings gap. Second, they want to increase the earnings potential of households at the bottom of the earnings distribution. Our results suggest that childcare provision meets the first goal in lower earnings households. Childcare reduces the female child penalty of mothers below the median of the households earnings distribution. A decrease in male earnings compared to a situation with no childcare, however, counterbalances this increase in female earnings, resulting in a zero effect on earnings at the household level. The finding that childcare reduces the strain on fathers in lower-earnings households to compensate for at least part of the earnings drop of their partner represents a desirable, though frequently ignored, side effect. Childbirth thus decreases household earnings by around 20 percent independently of whether childcare is available or not, but reduces the gender earnings gap by reducing the child penalty and increasing the female income share within the household.

We validate the interpretation of our findings by studying competing alternative mechanisms behind the effects. We show that i) the exploited treatment is effective in increasing the take-up of childcare, ii) individuals do not change their fertility decision in anticipation of the introduction of childcare, that iii) selective mobility is unlikely to drive our results, iv) the municipalities that open childcare facilities between 2001 and 2015 do not systematically differ from other municipalities in the canton of Bern with respect to the impact of children on female earnings, v) our results are not driven by differential time trends in municipalities introducing childcare, and vi) our estimation approach does not yield a significant effects in case of placebo introduction dates of childcare facilities. In a final step, we briefly discuss the role of gender norms as a driving force of the child penalty.

Our findings contribute to several strands of literature. First, we contribute to the growing literature on employment effects of parenthood (see, e.g. Angelov et al., 2016; Bütikofer et al., 2018; Kleven et al., 2019a,b) and extend it by studying the differential impact of childcare. Our findings are in line with the evidence provided by Olivetti and Petrongolo (2017) that the institutional setting is crucial for the extent of the child penalty. ${ }^{6}$

Second, our findings contribute to the large literature on the effect of childcare on maternal employment in general. Most of the empirical evidence on the effects of childcare availability on maternal labor outcomes focuses on the extensive margin. The evidence in early work, reviewed by Blau (2003) and Blau and Currie (2006), is mixed. More recent

\footnotetext{
${ }^{6}$ We are aware of two ongoing projects (Girsberger et al., 2019; Bönke et al., 2019) which assess the effect of parental leave policies on the child penalty.
} 
studies take the inherent endogeneity between childcare availability, childcare costs, and maternal labor supply into account. While childcare could affect maternal employment, employed mothers could also induce a higher demand for such services and drive its supply. These studies exploit quasi-experimental settings to draw causal conclusions.

One line of studies exploits large childcare expansions with a simultaneous introduction of childcare subsidies for mothers in general. Some of these studies find effects only for subgroups, such as single mothers (see Gelbach, 2002, and Cascio, 2009, for the US, and Goux and Maurin, 2010, for France) or less skilled mothers (see Cascio and Schanzenbach, 2013, for the US). Other studies find more substantial effects, documenting increases in maternal participation rates and hours worked (see Lefebvre et al., 2009, Haeck et al., 2015, and Lefebvre and Merrigan, 2008, for Canada, Müller and Wrohlich, 2020, and Bauernschuster and Schlotter, 2015, for Germany, and Nollenberger and Rodríguez-Planas, 2015, for Spain). The heterogeneous findings in these prior studies might be explained by private childcare arrangements, with a larger availability in the US or France than in Germany or Spain. The differences described above may therefore reflect differences in take-up rates related to the intervention, with the expansion of public childcare crowding out private arrangements in the former case and increasing availability of childcare in the latter.

Another line of studies uses large increases in childcare subsidies, with no increase in availability or take-up rates (see Givord and Marbot, 2015, for France, Lundin et al., 2008, for Sweden, or Havnes and Mogstad, 2011, for Norway) and finds no or very modest effects on mothers' employment or earnings.

Importantly, the existing literature studies the impact of childcare independently of the timing of the expansion with respect to the birth of the first child. We, in contrast, argue that it is the access to childcare at this time which is particularly relevant. We focus on the effect of childcare at the moment mothers make the decision to return to work after the birth of their first child. In that, we combine the literature on employment effects of parenthood and the effect of childcare on parental employment. Administrative data on the whole population of the canton of Bern in Switzerland allow us to study both the intensive and the extensive margin of mothers' and fathers' labor market decisions. Over the years 2001-15, for which we have data, 59 of 401 municipalities in the canton of Bern introduced childcare, whereas 26 already had childcare facilities before $2001 .^{7}$ On top of this considerable expansion in childcare provision, we exploit the introduction of subsidized care, which some municipalities only started offering several years after the opening of a childcare facility. Though we have to rely on limited variation for this analysis, it allows us to distinguish between an availability and a price effect and contribute to the reconciliation of previous strands of literature.

The remainder of the paper is organized as follows. Section 2 lays out our empirical strategy, before Section 3 describes the data basis. Section 4 presents our results on the

\footnotetext{
${ }^{7}$ In 2001 , around $18.5 \%$ of taxpayers in our data were living in municipalities that introduced childcare between 2001-15, whereas 37\% were living in municipalities, including the canton's largest municipalities Bern and Biel, which already had childcare before 2001.
} 
overall child penalty in Switzerland and on the differential impact of childcare availability. Section 5 validates our estimation strategy and discusses the role of norms in the child penalty, before Section 6 offers some concluding remarks.

\section{Empirical strategy}

We rely on an event study approach to investigate the effect of childcare on parents' work arrangements after the birth of their first child. We study how female and male earnings and participation rates change after the birth of their first child and estimate differential effects depending on whether there is access to childcare in the year of birth. We briefly describe our baseline event study approach before we present the strategy to identify the differential effect of childcare availability.

We build upon the event study approach proposed by Kleven et al. (2019a) to study parental labor market outcomes after the birth of their first child conditional on pre-child choices. In this setting, the birth year of the first child is denoted as event time $t=0$ for each parent, and all prior and subsequent years are defined relative to this event. We regress labor market outcomes on event time indicators and covariates using equation

$$
Y_{i s t}^{g}=\alpha+\sum_{j=-3}^{j=6} \beta_{j}^{g} \times I[j=t]+\gamma_{\text {age }}^{g}+\delta_{s}^{g}+\mu_{\text {married }}^{g}+\nu_{i}^{g}+u_{i s t}^{g},
$$

where $Y_{i s t}^{g}$ describes the labor market outcome of individual $i$ of gender $g$ in year $s$ at event time $t$. The event time parameters $\beta_{j}^{g}$, with $\beta_{-1}^{g}=0$, identify the change in outcomes relative to the year prior to the birth of the first child, $t=-1$. We further add a full set of age effects to control for life-cycle effects $\left(\gamma_{a g e}^{g}\right)$, year effects to control for any time varying shocks $\left(\delta_{s}^{g}\right)$, and individual fixed effects to control for time invariant individual characteristics $\left(\nu_{i}^{g}\right) .{ }^{8}$ We further include an indicator variable for being married prior to the birth of the first child $\left(\mu_{\text {married }}^{g}\right)$.

In line with a recent contribution by Schmidheiny and Siegloch (2019), we apply binning at both ends of our event time window. We keep individuals in years outside of the range of our event time window, which runs from three years before to six years after birth of the first child, in our sample. Outside this window, however, we bin the event time dummies at -3 and 6 . The event time estimate $\beta_{-j}^{g}=\beta_{-3}^{g}$ thus identifies the effect for all $t \leq-3$ and $\beta_{j}^{g}=\beta_{6}^{g}$ identifies the effect of $t \geq 6$. Binning ensures the separate identification of the event time indicators while flexibly controlling for age and time in the presence of individual fixed effects.

We run the estimation in levels rather than in logs. This allows us to keep all individuals in our sample, even if their earnings drop to zero at some point. A non-negligible fraction of women stops working for some time after the birth of the first child. To

\footnotetext{
${ }^{8}$ By construction, the individual specific effects also capture municipality of child birth fixed effects, thus controlling for level differences between municipalities.
} 
convert the estimated earnings changes after the birth of the first child into percentage changes relative to the year before the birth of the first child, we divide the event time estimates $\hat{\beta}_{j}^{g}$ by counterfactual earnings, i.e. predicted earnings in the absence of a child at event time $t$. The percentage effect is thus defined as $\hat{P}_{t}^{g}=\hat{\beta}_{j}^{g} / E\left[\hat{Y}_{i s t}^{g} \mid t\right]$ with $\hat{Y}_{i s t}^{g}=\hat{\alpha}+\hat{\gamma}_{\text {age }}^{g}+\hat{\delta}_{s}^{g}+\hat{\mu}_{\text {married }}^{g}$. Due to this nonlinear transformation of the parameter estimates, we apply a non-parametric bootstrap to get consistent standard errors for $\hat{P}_{t}^{g}$. For identification, this event study approach relies on the assumption that average earnings would develop smoothly in the absence of children, an idea which we rationalize in the following framework.

In line with Kleven et al. (2019a), we assume that earnings $Y_{i t}$ of individual $i$ at time $t$ are a function of the number of children $k_{i t}$ present at time $t$, the anticipated lifetime path of fertility of individual $i$, denoted by $\mathbf{k}_{\mathbf{i}}=\left(0, \ldots, k_{i t}, k_{i T}\right)$, a set of earnings determinants $\mathbf{x}_{\mathbf{i t}}=\mathbf{x}\left(k_{i t}, \mathbf{k}_{\mathbf{i}}, \mathbf{z}_{\mathbf{i t}}\right)$ that depends on children and expected fertility, and $\mathbf{z}_{\mathbf{i t}}$, which is a set of earnings determinants uncorrelated with children,

$$
\begin{aligned}
Y_{i t} & =F\left(k_{i t}, \mathbf{x}_{\mathbf{i t}}, \mathbf{z}_{\mathbf{i t}}\right) \\
& =F\left(k_{i t}, x\left[k_{i t}, \mathbf{k}_{\mathbf{i}}, z\left(p_{i t}, \mathbf{p}_{\mathbf{i}}\right)\right], z\left(p_{i t}, \mathbf{p}_{\mathbf{i}}\right) .\right.
\end{aligned}
$$

This framework allows for two effects of children on earnings. First, there is a pre-child effect of future children given current children $k_{i t}$, which is, for instance, reflected in individuals opting for less education or family friendly careers in anticipation of children. The pre-child effect is already captured in the outcomes prior to the birth of the first child, which are differenced out and cannot be identified. The post-child effect captures the direct effect of current children $k_{i t}$ on earnings, and the indirect effect of the birth of a child through employment decisions, which is the indirect effect through earnings decisions $x_{i t}$ impacted by the birth of a child.

We assume that mean earnings develop smoothly in the absence of children. This allows for the identification of the post-child effects in the event study. Introducing controls for earnings determinants which are uncorrelated with children, $\mathbf{z}_{\mathbf{i t}}$, allows us to relax the smoothness assumption. These direct controls for earnings determinants include both an individual fixed effect $\mathbf{p}_{\mathbf{i}}$, capturing characteristics such as ability or education, and time varying determinants, like the age of an individual or time trends, $p_{i t}$. Conditional on $\mathbf{z}_{\mathbf{i t}}$, the event study identifies the female and male child penalty even in the long run. Contrary to the short run effect, the long run effect captures the effect of total lifetime fertility instead of the effect of just the first child. In our setting, we include a full set of age and year fixed effects, as well as individual fixed effects, which control for a large part of $\mathbf{z}_{\mathbf{i t}}$. This basic approach allows us to estimate the overall effect of children on parents' earnings and labor force participation.

In addition to estimating the child penalty, we aim to identify the differential effect depending on whether there is childcare provision in the municipality of residence in the year of birth of the first child. To this end, we exploit the staggered introduction of child- 
care facilities across the municipalities in the canton of Bern. ${ }^{9}$ While the introduction of childcare in a given municipality is likely endogenous to demand to some extent, we assume that its precise timing is not. We validate this assumption by comparing child penalties in municipalities opening a childcare facility in our observational window to child penalties in municipalities which do not have a childcare facility by the end of the time window we study. Our results show, that in the absence of childcare, their child penalties are comparable. This alleviates the concern that individuals living in municipalities opening childcare facilities earlier systematically differ from individuals living in municipalities with no childcare facilities. Furthermore, we focus on municipalities which did not have childcare at the beginning of our sample period, but introduced it at some point within our observational window.This strategy allows us to identify the effect of childcare on the child penalty under the assumptions that individuals do not change their fertility decisions in anticipation of the introduction of childcare, and that there is no spatial selection of couples with a preference for continuing their employment at a high level into municipalities offering childcare. We validate the robustness of our results with respect to selective fertility and spatial selection in Sections 5.2 and 5.3.

In order to study whether the overall child penalty depends on the availability of childcare and to estimate the differential effect, we interact the event time dummies of our baseline model with the indicator $\mathrm{Care}_{i}$, which assumes value 1 if there is a childcare facility in the municipality of residence in the year of birth of the first child, and 0 otherwise. This results in the specification

$$
\begin{aligned}
Y_{i s t}^{g}=\alpha+\sum_{j=-3}^{6} \beta_{j}^{g} I[j=t] & +\sum_{j \neq-1} \rho_{j}^{g} I[j=t] \times \text { Care }_{i} \\
& +\gamma_{\text {age }}^{g}+\delta_{s}^{g}+\mu_{\text {married }}^{g}+\nu_{i}^{g}+u_{i s t}^{g},
\end{aligned}
$$

where $\rho_{j}^{g}$ captures the difference in child penalties if in the year of birth of the first child there is a childcare facility in the municipality of residence, and thus measures the differential effect of childcare. The percentage effect is defined as $\Delta \hat{P}_{t}^{g}=\hat{\rho}_{j}^{g} / E\left[\hat{Y}_{i s t}^{g} \mid t\right]$. All other variables are defined as above. As before, we use a non-parametric bootstrap to calculate consistent standard errors.

\section{Data}

\section{Individual data and sample}

Our analysis draws on administrative tax data for the Swiss canton of Bern. With a population of about 1 million, the canton of Bern represents approximately one-eighth of the total population of Switzerland and includes both urban centers and rural municipalities, some of which are located in alpine regions. Around 11 percent of the population live in

\footnotetext{
${ }^{9} \mathrm{~A}$ federal impulse program provided financial support for the expansion in childcare facilities during our sample period. Starting in 2003, the federal government provided funding to public and private entities to cover the fixed costs of opening new facilities if they could document that there was sufficient demand.
} 
municipalities that are French speaking, whereas in the majority of municipalities German is the official language. This makes the canton of Bern a good mirror of Switzerland as a whole. The tax data covers all individuals paying taxes in the canton of Bern, i.e., all individuals who live in the canton of Bern on 31 December of a year and are aged 18 or older. ${ }^{10}$

We draw on data for the years 2001 to 2015 and can track individuals over time as long as they do not leave the canton. Even though Swiss law treats married couples as one entity, the data allow us to distinguish between labor earnings contributed by each spouse. ${ }^{11}$ We define the birth year of an individual's first child as the year in which he or she first files child deductions in their tax return. ${ }^{12}$ To identify the birth year of the first child, we need to restrict our sample to parents who are married in at least one year during our observational period. ${ }^{13}$ Relying on marriage allows us to identify both parents under reasonable assumptions. This restriction is necessary because if parents are not married, either of them can file for the deduction. ${ }^{14}$ While we do not require our panel data to be balanced, we exclude individuals with missing information between the first and the last year they appear in our data. ${ }^{15}$

In total, we identify 340,233 couples that are married at some point, associated with 4.07 million couple-year observations in our data. Restricting our sample to mixed sex couples where both partners are aged 20 to 45 and who file child deductions in some year results in 41,309 couples with 476,104 million couple-year observations. We further restrict the sample to couples where neither spouse relocates in the year prior to or after the birth of their first child, which we observe during at least five consecutive years between two years before and two years after the birth of the first child, and where neither spouse declares self-employed earnings. ${ }^{16}$ This renders a sample of 13,275 couples with 145,978 couple-year observations.

\footnotetext{
${ }^{10}$ Individuals under the age of 18 with considerable earnings also pay taxes. This is, however, quite rare and, as explained below, we exclude individuals below the age of 20 from our sample.

${ }^{11}$ In the year a couple get married or divorced, e.g. there are multiple entries, one for the time period the couple are taxed jointly and one for the time period they are taxed individually. In those cases, we aggregate the entries to determine total earnings for that year.

${ }^{12}$ Note that this procedure does not allow us to distinguish between biological children and adoptions. Using data from Denmark, however, research by Kleven et al. (2020) suggests that the child penalty is the same for biological and adopted children.

${ }^{13}$ Given that at least 76 percent of individuals who have children in our sample are married at some point, this is not a restrictive sample definition.

${ }^{14}$ We have separate identifiers for both spouses in couples, which the tax authority continues to use before and after individuals are married. We exclude same-sex couples, who can also file their taxes jointly. We also exclude individuals who were married to different spouses during our sample period because this makes it harder to identify both parents.

${ }^{15}$ Observations for some years in between the first time an individual is observed and the final year the individual is observed may be missing if an individual does not continuously live in the same canton. Our data does not allow us to follow individuals across cantonal borders.

${ }^{16}$ Restricting to non-movers alleviates concerns of selective mobility. We discuss this point in more detail in Section 5.3. We exclude couples with earnings from self-employment because tax considerations might incentivize self-employed to shift earnings across years and between spouses.
} 
Since 2005, there have been 14 weeks of paid maternity leave in Switzerland . As benefits received during maternity leave depend on pre-child earnings, the introduction of paid maternity leave may not only affect outcomes after the birth of a child but potentially also maternal earnings before giving birth. To avoid any bias induced by the introduction of paid maternity leave, we further restrict the sample to parents of children born after 2004. Finally, we exclude all couples where either partner was not employed during the three years before the birth of the first child. In the end, we are left with 10,372 couples associated with 112,500 couple-year observations.

\section{Municipality level childcare data}

We complement the administrative individual data with self-collected information on the availability of childcare in the municipality of residence.

In 2001, there were 401 municipalities in the canton of Bern. Provision of childcare varies substantially across municipalities. The office of public education of the canton of Bern ("Erziehungsdirektion Bern") provided us with a list of daycare facilities for the year 2018. We then contacted each of these facilities via mail and/or phone individually to inquire the year in which they opened and whether there were any comparable services in the municipality before that date. The covered time span is marked by a considerable expansion of childcare availability in Bern. While there were only 26 out of 401 municipalities (6.4\% of municipalities, covering around $37 \%$ of the canton's population) offering childcare before 2001, there were 97 (24\% of municipalities covering $71 \%$ of the canton's population) in 2015 (at the end of our sample). We managed to collect the opening year of the first childcare facility for 59 of the 71 municipalities, which opened a childcare facility between 2001 and 2015. These cover around 18.5\% of the canton's population. ${ }^{17}$ The treatment year is defined as the year in which the first facility opened. Figure 1 visualizes the location and the childcare opening year of these 59 municipalities within the canton of Bern.

In the canton of Bern, there are both facilities with subsidized childcare places and facilities without. The main distinction between the two is that facilities with subsidized childcare places are subject to additional regulation concerning their pricing and prioritization of children. ${ }^{18}$ Prices for subsidized childcare are set at the cantonal level and depend on parents' income, wealth, and family size, with a minimum price of CHF 0.77 per hour and a maximum price of CHF 12.15 per hour in 2018. ${ }^{19}$ Additionally, for sub-

\footnotetext{
${ }^{17}$ In the remaining 12 municipalities, there was at least one facility which we were not able to reach or that refused to communicate their opening year. As we are not able to define whether there was a childcare facility at the time of birth of the first child, we exclude these municipalities from our sample.

${ }^{18}$ Regulations for facilities with subsidized care are available at https://www.belex.sites.be.ch/frontend/versions/1620 and regulations for facilities with no subsidized care at https://www.belex.sites.be.ch/frontend/versions/1223. This information is available in German and French.

${ }^{19} 1$ Swiss franc corresponded to $\$ 1.10$ on August 6, 2020 .
} 


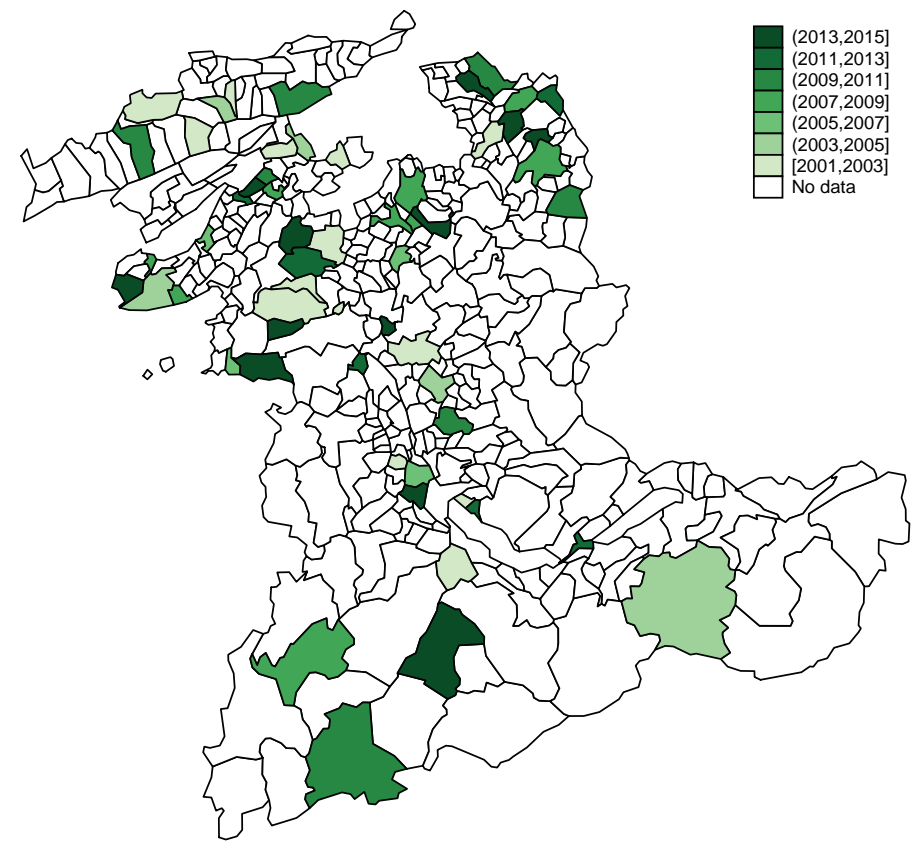

Note: This map visualizes the municipalities of the canton of Bern. The 59 municipalities that opened their first childcare facility between 2001 and 2015 are marked in green. The later the year in which the first childcare facility opened, the darker the color. "No data" indicates municipalities that introduced childcare before 2001, after 2015, not yet at all, or for which we were not able to determine the exact opening year.

sidized places, priority is given to families relying on two incomes and families requiring childcare due to their social situation or for integrative purposes. ${ }^{20}$

Of the 10,372 couples in our restricted sample, there are 4,721 who, in the year of birth of their first child, live in municipalities which either have no childcare facilities or which have facilities but were not able to provide information on opening dates. Another 3,692 live in municipalities that offer childcare, but opened their facilities before 2001 . The exclusion of these cases leaves us with a sample of 1,959 couples, associated with 21,437 couple-year observations, who, in the year of birth of their first child, live in one of the 59 municipalities opening a childcare facility between 2001 and 2015. Descriptive statistics for this sample, as well as for the sample of couples living in municipalities with no childcare facilities as of 2015 and for couples living in municipalities which open a childcare facility before 2001, can be found in Appendix Table A.1. The samples are comparable in both cases.

\footnotetext{
${ }^{20}$ A two parent family with one child, no wealth, and a net income of CHF 46,800 would pay the minimum price. The price is decreasing in the number of children in the household and increasing in family wealth and income. The maximum price is applicable to a two parent family with one child, no wealth, and a net income of CHF 163,800.
} 
Besides earnings, we also study the extensive margin of employment as an outcome. We consider an individual to be employed if their earnings are positive in a given year.

\section{Results}

We present our empirical analysis in four steps. In a first step, we show how the birth of a first child affects female and male earnings and participation rates. This allows us to compare the size of the estimated penalty with previous studies. In a second step, we turn to the impact of the presence of childcare in the year the first child is born on parental earnings and participation rates. Here, we additionally evaluate the differential impact of subsidized childcare vs. non-subsidized childcare. In a third step, we study the heterogeneity of the effect depending on household earnings, and finally, we analyze the overall effect on total household earnings and female earnings shares.

\subsection{Assessing the child penalty}

We start by estimating the earnings and participation effects of becoming a parent. As described above, we condition our estimates on time fixed effects, life-cycle effects (age effects), and individual fixed effects (see Equation 1 for more details). Figure 2 presents the results for men and women and for our two main outcomes, individuals' earnings (total effect) and labor market participation (extensive margin).

Figure 2: Effect of parenthood on earnings and labor market participation

(a) Earnings

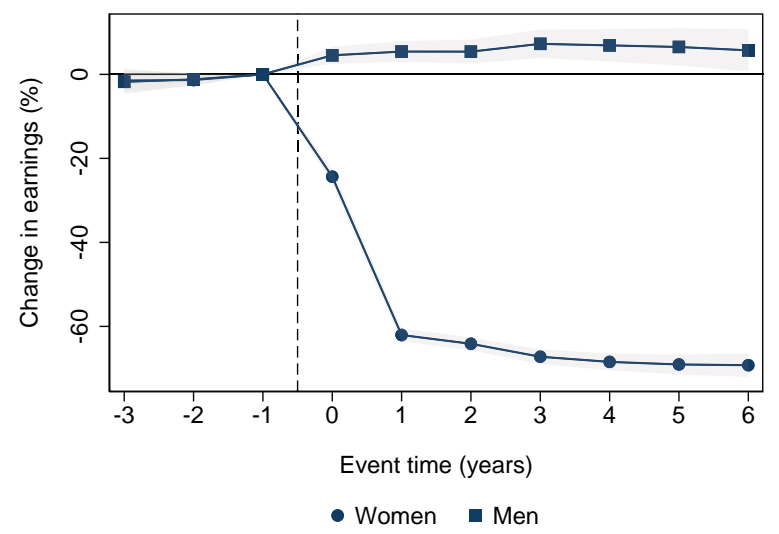

(b) Participation

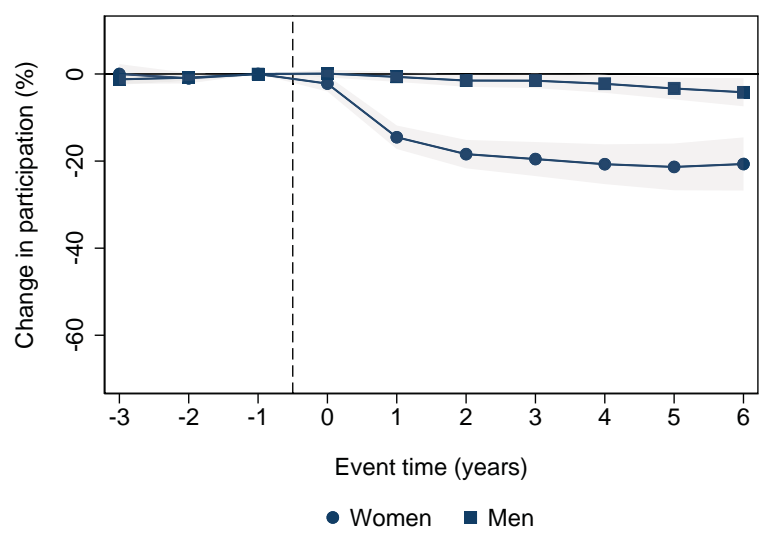

Note: Percentage effect of parenthood on earnings and participation relative to the year prior to the birth of the first child $(t=-1)$ for women and men. Confidence bounds are calculated applying a non-parametric bootstrap and are reported at the 5 percent level. The corresponding estimates can be found in Appendix A, column (1) of Tables A.2 (earnings) and A.4 (participation) for women, and column (1) of Tables A.3 (earnings) and A.5 (participation) for men. 
The left-hand panel of Figure 2 visualizes the effect of parenthood on earnings and the right-hand panel on individuals' labor market participation for both women and men. Before the birth of their first child, earnings and participation patterns of men and women evolve in parallel. After the birth of their first child, earnings diverge substantially. The earnings of mothers drop by 62 percent between the year prior to childbirth and the year after. $^{21}$ The earnings of men, in contrast, display a slight increase of 5.4 percent in the year after childbirth. ${ }^{22}$ Starting in year 2 after childbirth, the earnings of women and men start evolving in a roughly parallel fashion again. Six years or more after childbirth, we observe a decrease in women's earnings of 69 percent and an increase in men's earnings of 6 percent, which add up to a total child penalty of 75 percent. The participation rate of women initially drops by about 15 percent and by 21 percent in the long term. About 30 percent of the drop in women's earnings due to parenthood can be explained by participation in the labor market. The participation rate of men, in contrast, remains virtually unaffected by parenthood. It falls by about 4 percent. This is consistent with studies for other countries. ${ }^{23}$

The earnings penalty we document for Swiss women is comparable to the one documented for Germany (for numbers on Germany and 5 other countries, see Kleven et al., 2019b). However, while female participation rates in Germany are a major factor in explaining the earnings gap, with a reduction of 40 percent six years after the birth of the first child, female participation rates in Switzerland only decrease by 20 percent in the long run and remain stable after year three following the birth of the first child.

\subsection{The impact of childcare}

We next turn to evaluating whether the availability of childcare facilities in the year the first child is born impacts mothers' (and fathers') labor market attachment and helps reduce the child penalty. As described above, we estimate a fully interacted event study using an indicator set to one if there is childcare available in the year of birth of the first child.

\footnotetext{
${ }^{21}$ In the year of birth $(t=0)$, earnings include maternity leave compensation, which corresponds to 80 percent of earnings in the year prior to the birth of the child (with a maximum of CHF 196) per day. Paid maternity leave is 14 weeks. There is no paternity leave in Switzerland.

${ }^{22}$ This effect is to some extent mechanical. With the birth of the first child, employees receive child benefits as part of their earnings. Child benefits are due to the parent with higher earnings, which is usually the man. Statutory child benefits are approximately CHF 2,760 per child and year (rates may vary slightly from year to year). Many employers grant additional benefits which are often of similar magnitude for the first child, however, with the total amount of this additional benefit decreasing in the number of children. For employees of the canton, e.g., the total annual child allowance for the first child amounts to CHF 5,760, CHF 7,680 for two children, CHF 9,600 for three children, CHF 11,520 for four children, and 2,760 times the number of children for five and more children. Considering that within sample mean earnings of men at $t=-1$ are CHF 69,284, the child benefits for the first child correspond to an increase in mean earnings of 8.3 percent.

${ }^{23}$ The effect of parenthood on women's and men's earnings is rather similar for the other subgroups of municipalities, i.e., the municipalities that either open childcare facilities before 2001 or municipalities with no childcare facilities as of 2015. These results are discussed in Section 5.4.
} 
Figure 3: Effect of having a childcare facility in the year of birth of the first child

\section{Outcome: Earnings}

(a) Effect of parenthood

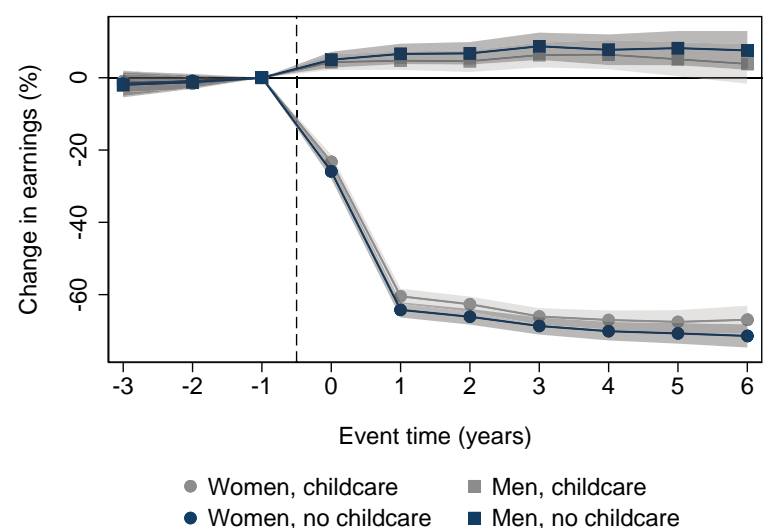

(b) Effect of childcare

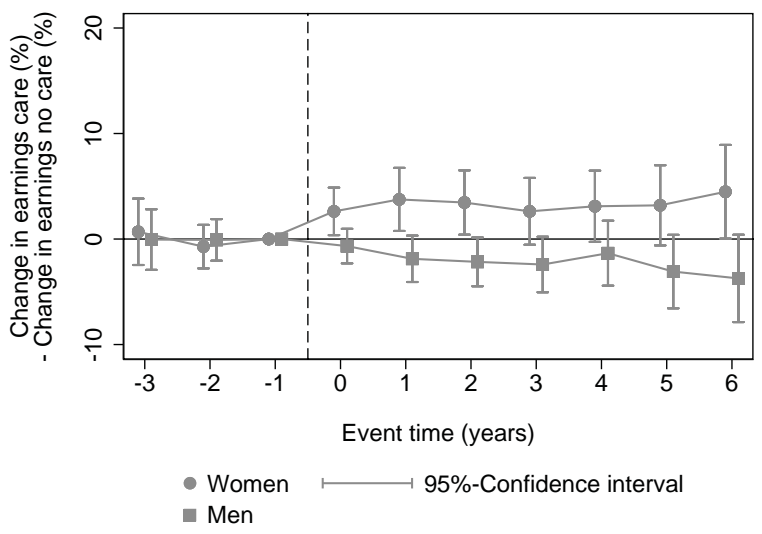

Outcome: Participation

(a) Effect of parenthood

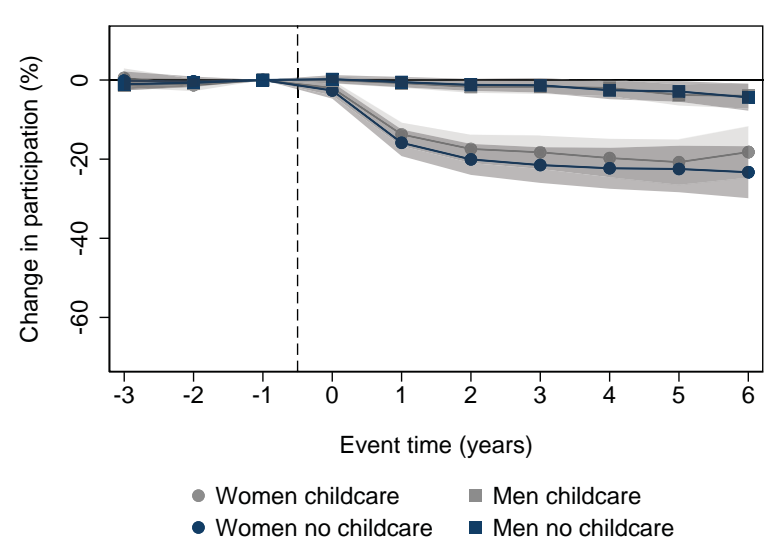

(b) Effect of childcare

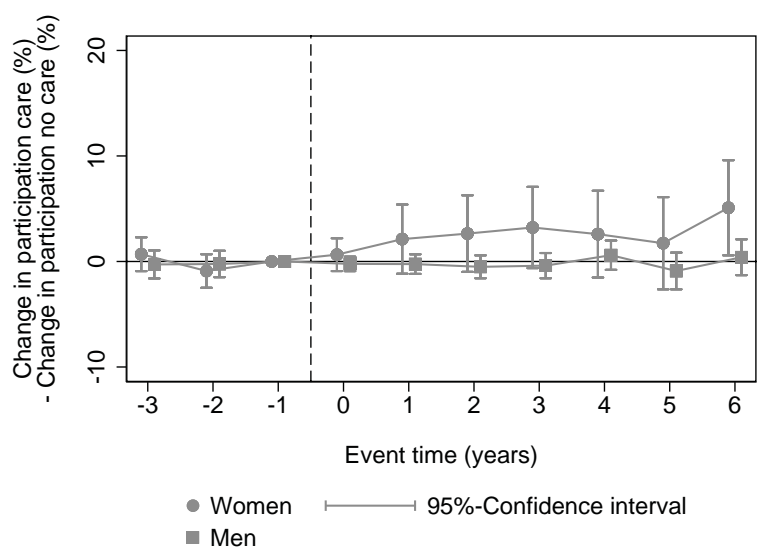

Note: These graphs show the effect of having a childcare facility in the municipality of residence in the year of birth of the first child. Panels (a) show the percentage effect of parenthood on earnings and the participation rate relative to the year prior to the birth of the first child $(t=-1)$ for women and men. Panels (b) display the difference in female and male earnings by the presence of childcare $\left(\rho_{j}^{g}\right)$. The confidence bounds are calculated applying a non-parametric bootstrap and are displayed at the 5 percent level. The corresponding estimates can be found in Appendix A, column (2) of Tables A.2 (earnings) and A.4 (participation) for women, and column (2) of Tables A.3 (earnings) and A.5 (participation) for men.

The upper panel of Figure 3 shows the effect of the birth of the first child on earnings, while the lower panel shows the effect on participation rates. As described before, we consider municipalities opening their first childcare facility between 2001 and 2015. Our strategy is to compare parents who had their first child after a childcare facility opened with parents who had their first child before. Again, we see that before the birth of their first child, the earnings of men and women evolve in parallel. Additionally, we see that before the birth of the first child, earnings of women and men, who at the time of birth 
live in a municipality with childcare and individuals who do not, evolve in parallel. After the birth of the first child, female earnings decrease by less if there is childcare compared to if there is not. The right hand panel shows this difference more clearly by plotting only the difference in the child penalties of individuals in municipalities with childcare at the time of birth compared to individuals in municipalities without. In the long run, female earnings are approximately 4.5 percentage points higher if there is childcare in their municipality of residence in the year of birth of their first child. In other words, childcare reduces the female child penalty by 6.3 percent. The difference is significant at the 5 percent level. Male earnings are approximately 3.7 percentage points lower in the long run if there is childcare in their municipality of residence in the year of birth of their first child. This result is intuitive given that, with the positive effect of childcare on female earnings, men do not have to increase their earnings by the same amount after the birth a child to, at least partly, make up for lost partner earnings. This difference is significant at the 10 percent level.

The bottom panel of Figure 3 reveals that childcare does not affect men's labor market participation. In the short run, there is no clear effect on female labor market participation either. Though less precisely estimated, there is a long term effect. The presence of childcare at the time of birth increases female participation by 5.1 percentage points six or more years after childbirth, corresponding to a 22 percent reduction in the drop of labor market participation for women we observe after the birth of the first child. This implies that participation fully accounts for the effect of childcare on the female child penalty when a woman's first child is in school. In the year of birth itself, as well as in the five subsequent years, however, the effect on participation is never statistically significant and the point estimate is mostly smaller than the point estimate on the total effect. This suggests that childcare allows mothers of young children to increase their workload through part-time work arrangements, which are common in Switzerland.

\section{The role of subsidized childcare}

The above results indicate that the presence of childcare increases earnings of women after the birth of the first child (reduces the child penalty). This raises the question whether the increase is driven by a pure availability effect or whether it is driven by a price effect. Subsidized childcare creates an incentive to substitute away from home care or more expensive private arrangements and to paid employment. In order to study this mechanism, we gather information on whether there is subsidized childcare in the municipality. Subsidies depend on parental income and can reduce hourly prices by more than 90 percent.

We are able to distinguish between the introduction of non-subsidized and subsidized care because 11 of the 59 municipalities which introduced childcare started offering financial support on average 4.5 years later. 353 of the 1,959 couples in our sample live in those 11 municipalities. In order to estimate the differential impact, we, technically, include an 
Figure 4: Effect of having subsidized childcare in the year of birth of the first child for women

(a) Effect of parenthood

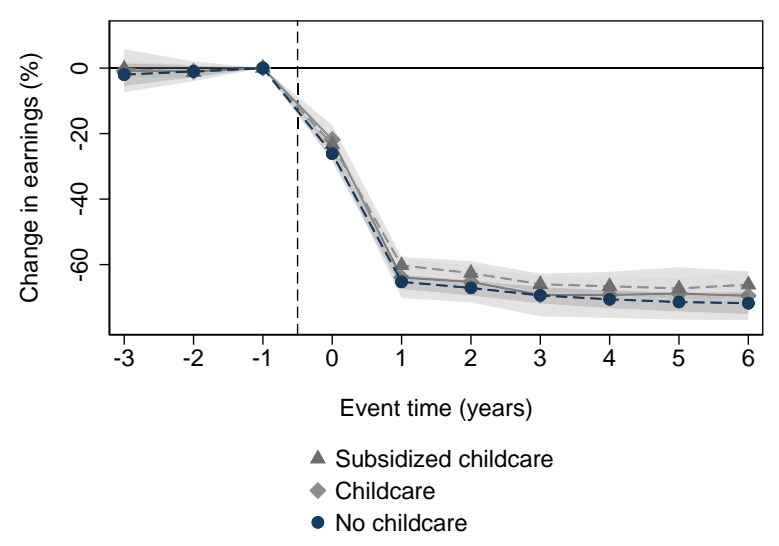

(b) Effect of childcare

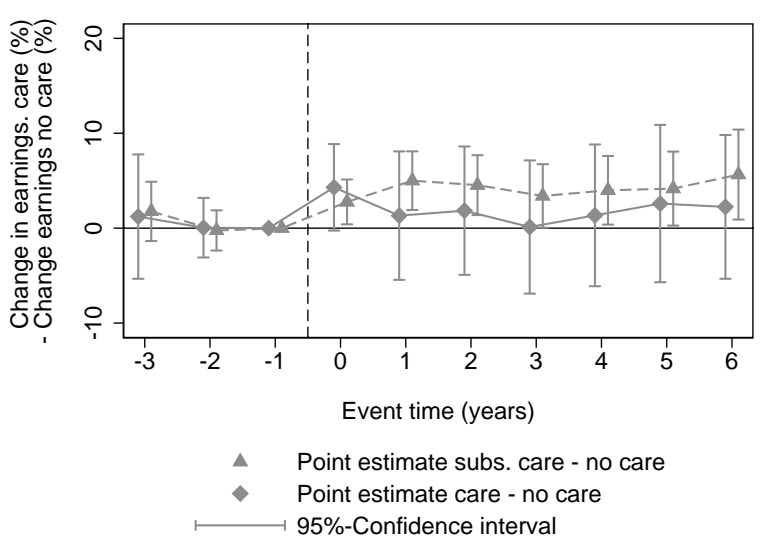

Note: Effect of having a childcare facility in the municipality of residence in the year of birth of the first child, distinguishing between subsidized and non-subsidized care. Panel (a) shows the percentage effect of parenthood on earnings relative to the year prior to the birth of the first child $(t=-1)$ for women. Panel (b) displays the estimated effect of childcare on the child penalty for women. The solid line displays the effect for non-subsidized care and the dashed line for subsidized care. Confidence bounds are calculated applying a non-parametric bootstrap and are displayed at the 5 percent level. The corresponding estimates can be found in column (5) of Table A.2 in Appendix A. The corresponding estimates for men can be found in column (5) of Table A.3 in Appendix A.

additional term in our estimation equation. We interact the event time dummies with a childcare indicator and an indicator for whether childcare is subsidized, as described in Equation 3. The left hand side of Figure 4 presents how female earnings change after the birth of the first child. We distinguish between mothers living in a municipality with no childcare at the time of birth of their first child, mothers living in a municipality with childcare but no subsidies, and mothers in a municipality with subsidized childcare. The right hand side shows the differences between no childcare and non-subsidized childcare (solid), and no childcare and subsidized childcare (dashed).

While these results are based on rather few observations in municipalities switching from non-subsidized to subsidized childcare, the results indicate that financial support amplifies the abating effect of childcare on the child penalty. The introduction of subsidized childcare increases maternal earnings by 7.8 percentage points compared to no childcare, which is displayed by the dashed line, or by one-tenth of the total penalty of mothers in municipalities without childcare. The effect of childcare without financial support is still positive, albeit small and not significantly different from no childcare, as shown by the solid line in the right panel of Figure 4. We do not find a differential effect for participation rates. The corresponding results can be found in column (5) Appendix Table A.4. These results suggest that subsidies play a complementary role in childcare provision and without subsidies, reductions in the child penalty may be considerably smaller. The 
Figure 5: Effect of childcare for women by pre-child household earnings.

Outcome: Household earnings below sample median at $t=-1$

(a) Effect of parenthood

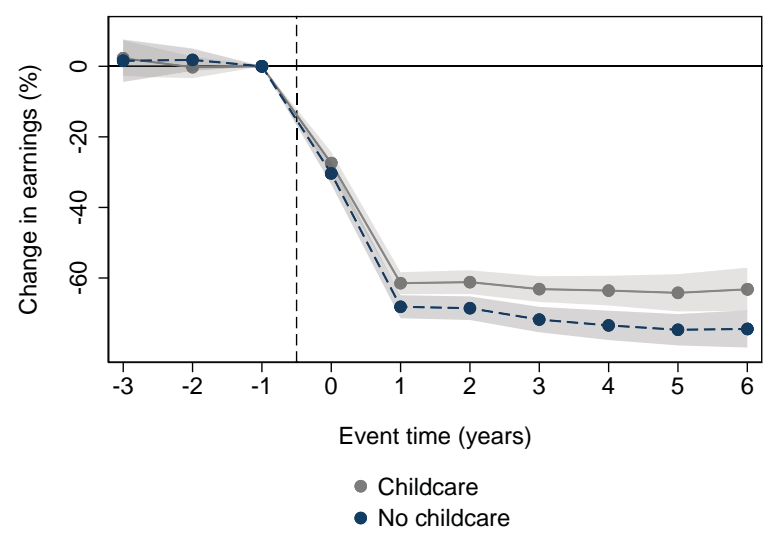

(b) Effect of childcare

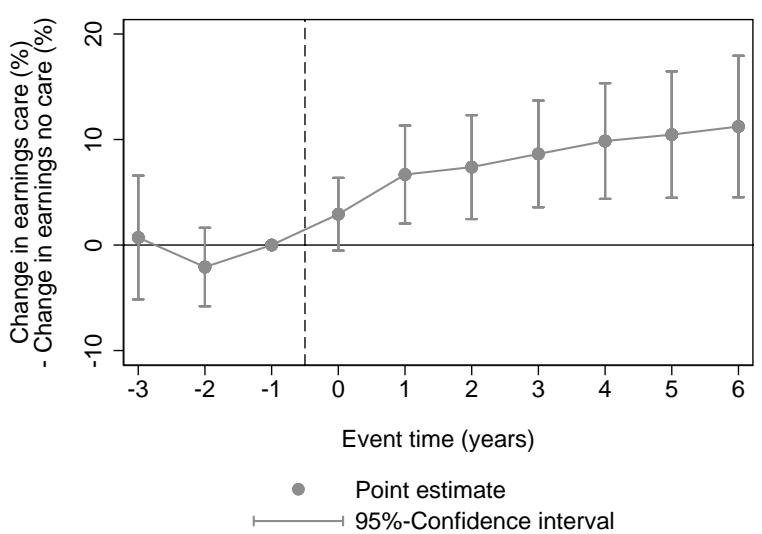

Outcome: Household earnings above sample median at $\mathrm{t}=-1$

(a) Effect of parenthood

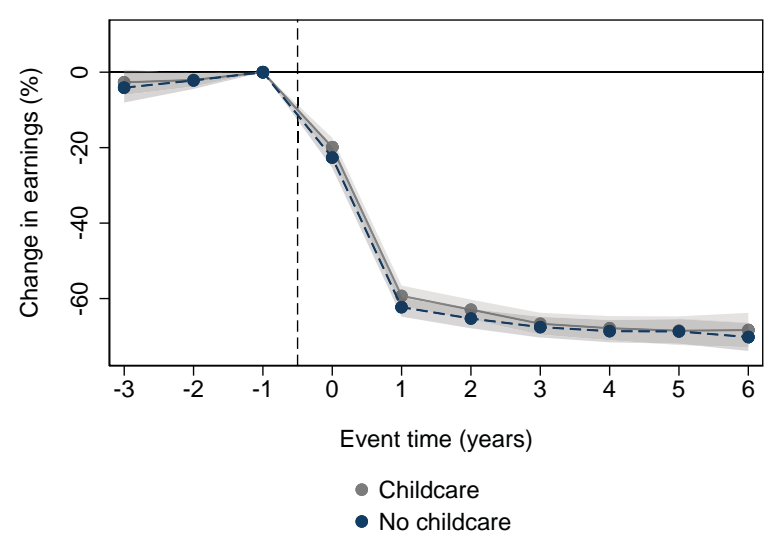

(b) Effect of childcare

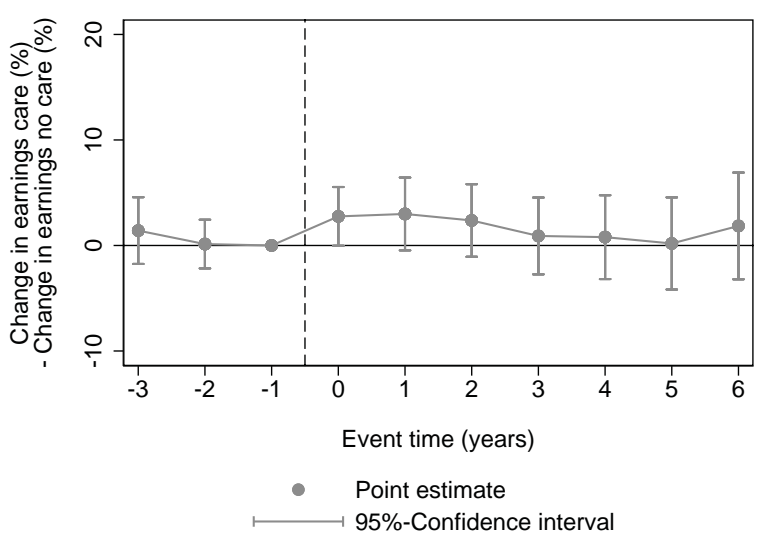

Note: Effect of having a childcare facilities in the municipality of residence in the year of birth of the first child on female earnings, by pre-child household earnings. The top panels show the effect for households with pre-child earnings below the sample median, the bottom panels for households with pre-child earnings above the sample median. The panels on the left show the percentage effect of parenthood on female earnings relative to the year prior to the birth of the first child $(t=-1)$. The panels on the right display the effect estimates of childcare. Confidence bounds are calculated at the 5 percent level of significance applying a non-parametric bootstrap. The corresponding estimates can be found in column (3) and column (4) of Table A.2 in Appendix A. The corresponding estimates for men can be found in column (3) and column (4) of Table A.3 in Appendix A.

corresponding results for men also suggest that the childcare effect is driven by subsidized care (see column (5) Appendix Table A.5). 


\section{Heterogeneity by household earnings}

Given the importance of subsidized childcare, one might expect to see a stronger effect for families with lower earnings (household earnings below or equal to sample median at $t=-1$ ) than for families with higher earnings (household earnings above sample median at $t=-1$ ). Figure 5 shows the estimates of the female child penalty and the effect of childcare for families with pre-child earnings below the sample median and families with pre-child earnings above the sample median. Panels (a) show that the long-term child penalty for women is comparable for both groups (around 70 percent of earnings). Panels (b) visualize the estimated effect of childcare for women by earnings group. In the presence of childcare, long-term maternal earnings are approximately 11.2 percentage points higher in lower-earnings families. Childcare thus reduces the female child penalty in lower-earnings families by about 15 percent. As shown in Appendix Table A.3, the documented increase in male earnings after the birth of the first child is also purely driven by lower-earnings households. In the absence of childcare, earnings of men in lower-earnings households increase by about 20 percent. Childcare reduces this increase in earnings of men in lower-earnings families by about 8.4 percentage points or by 38 percent, suggesting that childcare reduces the burden on men in lower-earnings families to make up for a loss in female earnings. The effect of childcare among higher-earnings families is negligible for both women and men, and not statistically significant in most event time periods.

The results for the labor force participation are in line with these findings. We find a somewhat less precisely estimated but positive long term impact for women lowerearnings households and no effect for higher-earnings households. The increase in the long term participation rate for lower-earnings households amounts to a substantial (37 percent) reduction in the participation drop in the absence of childcare. The corresponding estimates can be found in column (3) and column (4) of Table A.2 in Appendix A. The corresponding estimates for men can be found in column (3) and column (4) of Table A.3 in Appendix A.

Our results confirm that the effect of childcare is indeed stronger among lower-earnings families than among higher-earnings families. The effects on mothers' and fathers' earnings add up to a reduction of the total child penalty in lower-earning families by 20 percent.

\section{Childcare and earnings at the household level}

One policy goal of introducing childcare might be to reduce the drop in household earnings associated with the birth of a first child. As shown above, the presence of childcare at the time of birth of the first child increases female earnings and decreases male earnings compared to a scenario with no childcare. Both of these effects contribute to a reduction in the child penalty defined as the child-induced increase in the gender pay gap. If and how these two effects impact total household earnings, is a priori unclear. 
Figure 6: Effect of childcare on household earnings and the female earnings share

Outcome: Household earnings

Parenthood and household earnings

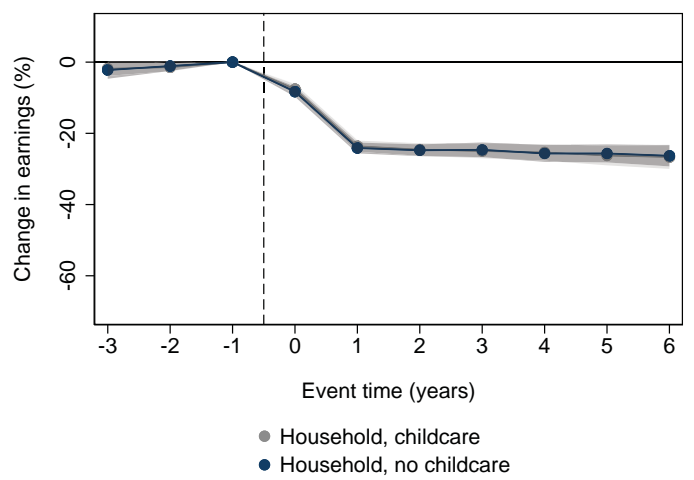

Effect of childcare on household earnings

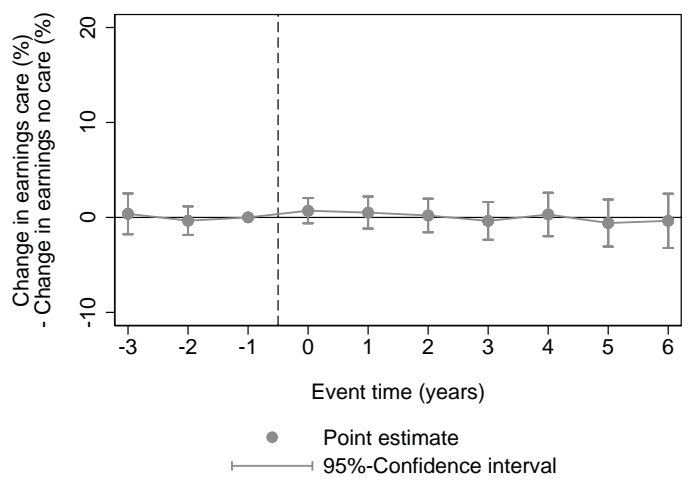

Outcome: Female earnings share

(a) Effect of parenthood

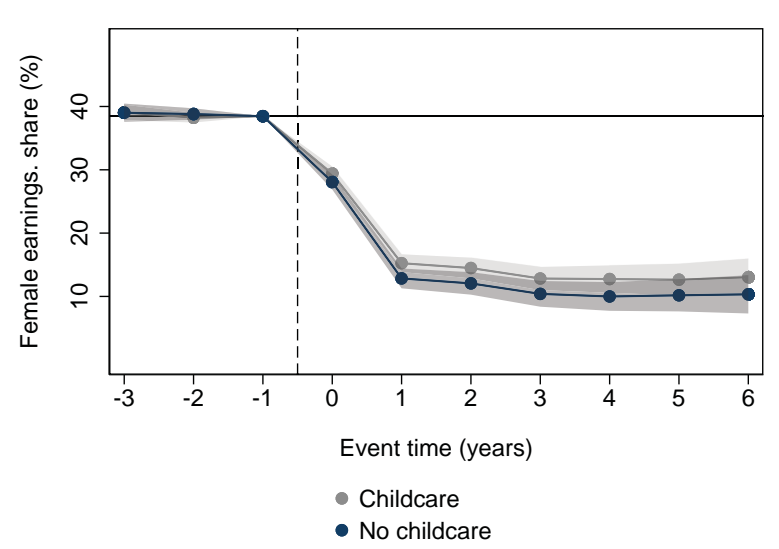

(b) Effect of childcare

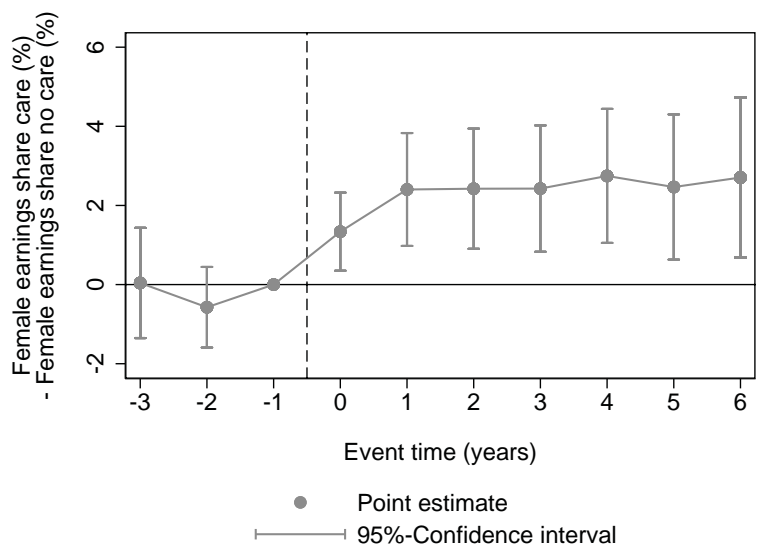

Note: This analysis follows a similar specification as the analyses in Figures 3 and 5, but with couple's total labor earnings and the female earnings share as dependent variable. Effect of having a childcare facilities in the municipality of residence in the year of birth of the first child. The top panels show the effect on household income, the bottom panels the effect on the female earnings share. The panels on the left show the percentage effect of parenthood relative to the year prior to the birth of the first child $(t=-1)$. The panels on the right display the differential effect of childcare on household earnings and the female earnings share respectively. The corresponding estimates can be found in Tables A.6 and A.7 respectively. Confidence bounds are calculated at the 5 percent level of significance applying a non-parametric bootstrap.

We present results on the development of total household earnings around the birth of the first child in the first row of Figure 6. On average, household earnings drop by more than 20 percent relative to the year before the child is born. We find no evidence for a systematic impact of childcare availability on total household earnings. While the effect of childcare is somewhat positive in the lower-earnings sample, it is small and not statistically significant at conventional levels (see Appendix Table A.6). The second row in Figure 6 shows the result of running an event study on female earnings shares as 
the dependent variable. We find that with childcare women's contribution to household earnings increases by 2.7 percentage points on average. The increase is more distinct in lower-earnings households where it amounts to 5.1 percentage points (see Table A.7 in the Appendix). This leads to the conclusion that while availability of childcare impacts relative earnings within the household, with women earning more and men earning less than in the absence of childcare, it does not impact overall earnings. This finding might of course be specific to high income countries like Switzerland.

\section{Discussion}

The results in Section 4 provide evidence for a positive impact of childcare on female earnings. In what follows, we explore a number of alternative mechanisms that could potentially bias our results. In these robustness checks, we mainly focus on the impact of childcare on the child penalty of women. We validate that i) the exploited treatment is effective in increasing take-up of childcare, ii) individuals do not change their fertility decision in anticipation of the introduction of childcare, iii) selective mobility is unlikely to drive our results, iv) municipalities opening childcare facilities between 2001 and 2015 do not systematically differ from other municipalities in the canton of Bern with respect to the impact of children on female earnings, v) our results are not driven by differential time trends in municipalities introducing childcare, and vi) our estimation approach does not yield a significant effect in case of placebo introduction dates of childcare facilities. In a final step, we briefly discuss the role of gender norms as a driving force of the child penalty.

\section{$5.1 \quad$ Take-up}

If our treatment indeed captures the increased availability of childcare, it should also affect take-up rates. While we cannot directly observe whether individuals in our sample have children enrolled in the facilities under consideration, the tax data include a variable on tax deductions for formal childcare arrangements. This provides us with information on whether parents make use of any kind of formal childcare. If our findings are driven by increased availability, we should observe an increase in tax deductions filed for childcare in the municipalities which open a childcare facility. ${ }^{24}$ While one might expect that the opening of childcare facilities induces some substitution away from privately organized care, overall we expect to see an increase in the claims of childcare deductions as there likely are households that previously could not afford childcare.

\footnotetext{
${ }^{24}$ We are not able to distinguish between types of childcare, namely whether it is claimed for care by nannies, by in-home daycare providers, or for institutional childcare. Nevertheless, if the effect on parental earnings is driven by the increase in childcare availability, we should see an increase in take-up rates of affected parents relative to parent who in the year of birth of their first child live in a municipality without childcare.
} 


\section{Outcome: Childcare deductions in $\mathrm{CHF}$}

(a) By childcare availability

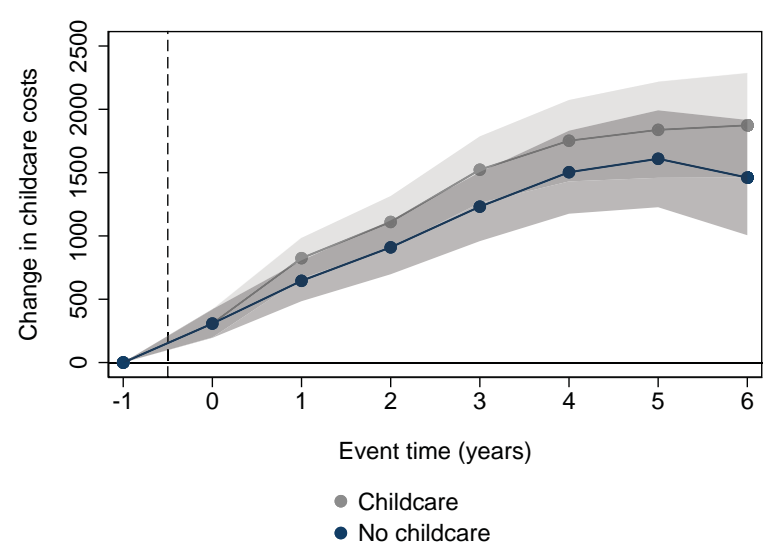

(b) Difference

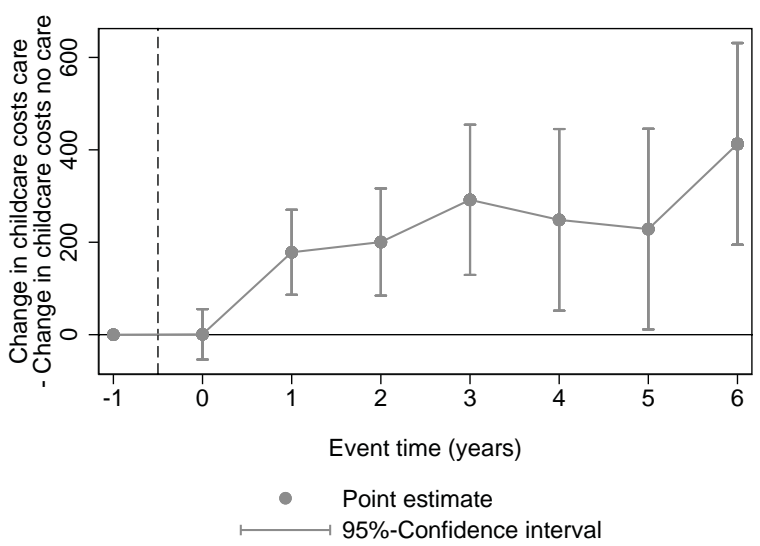

Outcome: Extensive margin

(a) By childcare availability

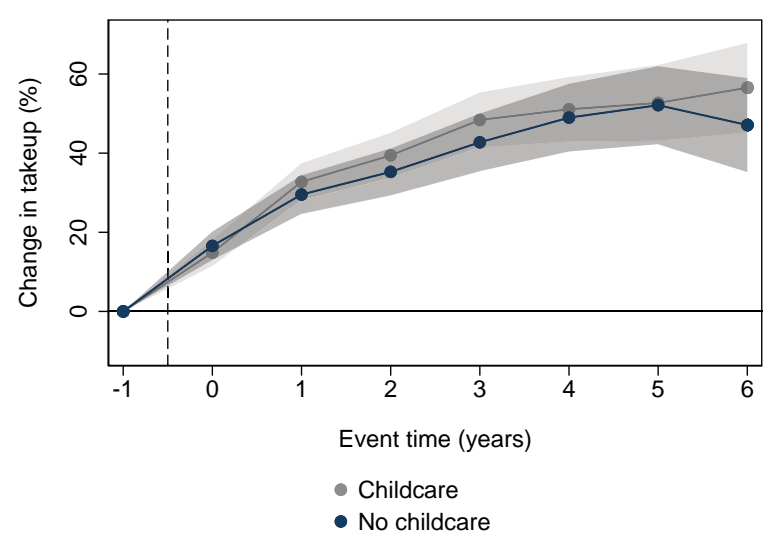

(b) Difference

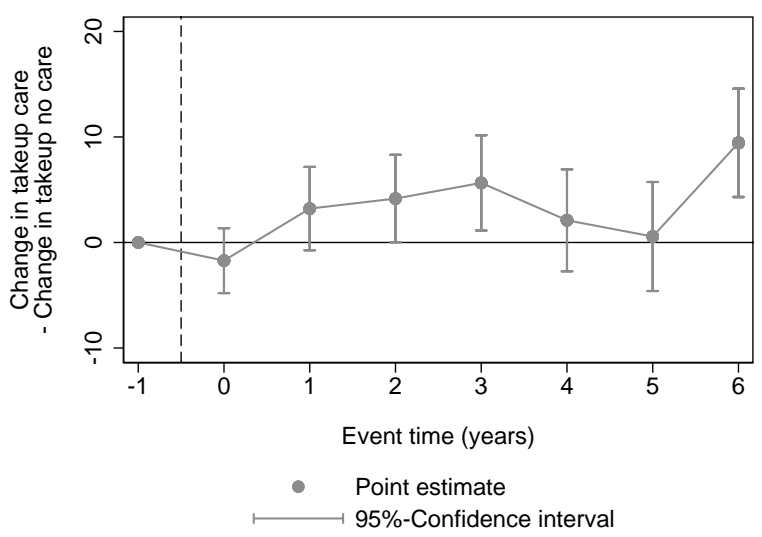

Note: Effect of having a childcare facility in the municipality of residence in the year of birth of the first child on childcare take-up. The top panels display the effect on the amount of total childcare deductions filed in CHF. The bottom panels display the effect on the extensive margin (whether any childcare deductions are filed). The panels on the left show how filings for childcare deductions evolve by availability and event time starting with the year of birth $(t=0)$. The panels on the right display the difference in takeup between individuals in municipalities with and without childcare. The corresponding estimation results can be found in Table A.8 in the Appendix.

To verify that take-up does indeed increase, we estimate an event study model where we compare filings for childcare deductions of couples who, in the year of birth of their first child, live in a municipality with and without childcare. We use two outcomes. The first outcome is the total amount deducted for childcare. ${ }^{25}$ The second outcome is an indicator variable set to one if a household files any childcare deductions, capturing the

\footnotetext{
${ }^{25}$ Note that this likely presents a lower bound. There is an upper bound on filings for childcare deductions per child and year of CHF 1,500 until 2008, CHF 3,000 in 2009 and 2010, and CHF 3,100 from 2011 onward. Average childcare deductions filed are CHF 2,672.
} 
extensive margin. Our analysis of take-up is restricted in that we cannot compare pretrends because filings for childcare deductions are naturally zero before the birth of the first child.

The upper panel of Figure 7 shows that parents' filings for childcare deductions in municipalities with childcare at the time of the birth of the first child exceed filings of parents in municipalities without childcare six years after the first child by, on average, CHF 413, or 28 percent. The positive differential materializes already in the first year after childbirth and increases thereafter. While there is no immediate effect at the extensive margin. Six years after the birth of their first child, parents in municipalities with childcare are 9.4 percentage points more likely to file childcare deductions.

These findings suggest that the exploited treatment indeed increases childcare take-up. It is, however, likely that we measure a lower bound in this analysis as there likely is some substitution between private and institutional care.

\subsection{Selective fertility}

One potential source of bias is selective or delayed fertility. If the woman is more attached to the labor market, couples might, for example, wait to have a child until there is childcare in their municipality of residence. If selective fertility were an issue, we would expect to observe an increase in fertility after the opening of a childcare facility. We run an event study on the probability of child birth around the opening of a childcare facility to test whether such selective fertility is a concern. In this analysis, the event time does not relate to the birth year of a first child, but to the year in which a childcare facility opens in the respective municipality. Similar to the above analyses, we include all individuals aged 20-45 who live in a municipality which introduced childcare during the years 20012015. This time, however, we do not restrict ourselves to individuals who necessarily have children at some point as the dependent variable is an indicator for whether an individual has a child in the respective year.

We find no indication for a change in fertility after the opening of a childcare facility, as shown in Figure A.1 in the Appendix. ${ }^{26}$ Selective fertility consequently appears unlikely to bias our results.

\subsection{Selective mobility}

Selective mobility is another potential source of bias. If parents with a strong preference to continue formal employment are more likely to move to municipalities with childcare around the birth of their first child, the effect we observe could, at least partially, be driven by changes in population characteristics. Individuals who selectively move to municipalities opening a childcare facility could also be more likely to remain in formal

\footnotetext{
${ }^{26}$ Appendix Table A.9 also shows estimates for an alternative difference-in-differences specification, which includes individuals in municipalities that did not have childcare by 2015 as a control group. Again, we do not find any indication that the introduction of childcare had an impact on fertility decisions.
} 
employment. In this case we would overestimate the impact of childcare on earnings and employment.

Figure 8: Effect of childcare for women who do not move between $t=-2$ and $t=2$

(a) Effect of parenthood

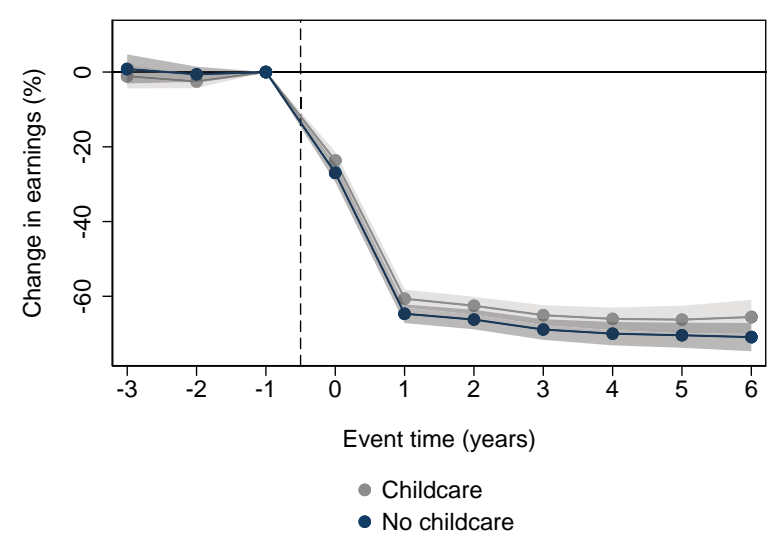

(b) Effect of childcare

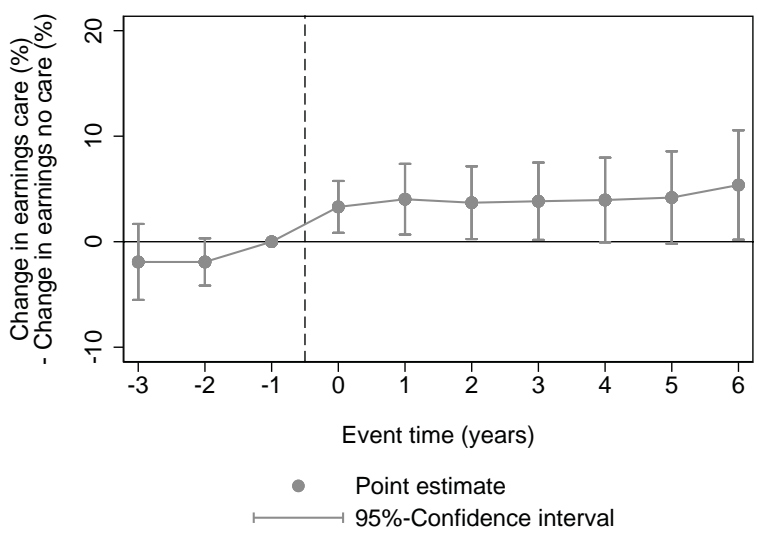

Note: Percentage effect of parenthood on female earnings relative to the year prior to the birth of the first child $(t=-1)$. The sample is restricted to individuals living in the same municipality between $t=-2$ and $t=2$. Confidence bounds are calculated at the 5 percent level applying a non-parametric bootstrap. The corresponding estimates can be found in column (1) of Table A.10 in Appendix A.

For our main estimation sample, we only consider individuals who remain in the same municipality during the year prior to and the year after birth. To check for the robustness of our findings, we now restrict the sample to individuals staying in the same municipality during the two years prior to and two years after the birth of their first child, i.e., we only use individuals who stay in the same municipality before pregnancy and for longer after the birth of the child. This should exclude couples which have selectively moved to the municipality. This restriction reduces our sample by about 25 percent. If these excluded couples were to drive our effect, the reduced sample should show a weaker or no impact of childcare.

Figure 8 (b) presents results of the differential effect of childcare based on this restricted sample of 'long-term' stayers. If anything, the results show a slightly stronger effect of the introduction of childcare on mothers' earnings. While the raw female child penalty without childcare is comparable among the original and the stayer sample, we find that the introduction of childcare reduces the adverse impact of parenthood on female earnings of long-term stayers by about 5.4 percentage points compared to a reduction of 4.5 percentage points in the main sample. Again, the effect seems to be driven by subsidized childcare (see columns (1) and (2) of Appendix Table A.10). The results for men are hardly affected (see column (1) and (2) of Appendix Table A.11). We conclude, that selective moving behavior is unlikely to bias our results. If anything, the introduction of childcare seems to affect the existing resident population more. 


\subsection{External validity}

For our main results, we only use the sample of municipalities within the canton of Bern which open a childcare facility between 2001 and 2015. So far, we have excluded all municipalities that either introduce childcare before 2001 or which have not introduced childcare facilities by the end of 2015. The sample of municipalities with no childcare by the end of 2015 can be used to test whether individuals who live in municipalities introducing childcare show different earnings patterns around the birth of a child than those in our main sample. Such differences might point to a systematic selection of the population in municipalities introducing childcare. Such selection might be a threat to the external validity of our results.

To test whether our results are likely to generalize, we test whether individuals residing in municipalities introducing childcare between 2001 and 2015 show similar child penalties in the years before the introduction of childcare as individuals in municipalities which have not introduced childcare by the end of 2015. To this end, we introduce an interaction term with an indicator (care $=1$ ) set to one for municipalities which introduce childcare at some point. Using only years before the introduction of childcare, this comparison allows us to test whether the child penalty differs systematically between the two types of municipalities. If they are comparable before the introduction of childcare, it might be valid to expect that they would also be comparable in their response to the introduction of childcare.

We find no evidence that female earnings evolve differently around the birth of a first child in the two types of municipalities, as shown in Appendix Figure A.2. Mothers' earnings decrease by about 60 percent in the year of birth and the following year. Earnings patterns of individuals living in municipalities which do not have a childcare facility by the year 2015 and municipalities where a childcare facility opened between 2001 and 2015 do not differ before the opening of the childcare facility. We interpret this as evidence that our results likely generalize to other municipalities.

\subsection{Differential time trends of municipalities introducing child- care}

We have shown that there is no systematic difference in the child penalty between municipalities which introduce childcare at some point and municipalities which do not. Furthermore, based on pre-trends, we have shown that individuals who, in the birth year of their first child, live in a municipality with childcare do not differ from individuals who do not. In a last step, we now want to make sure that the results are not driven by differing time trends of municipalities opening a childcare facility compared to municipalities with no childcare facility. To do that, we only use parents of children who are born within a narrow window around the introduction of childcare facilities, i.e., three years around the opening of a childcare facility. As these children were born "narrowly" before 
Figure 9: Effect of childcare for women and births within three years around facility opening

(a) Effect of parenthood

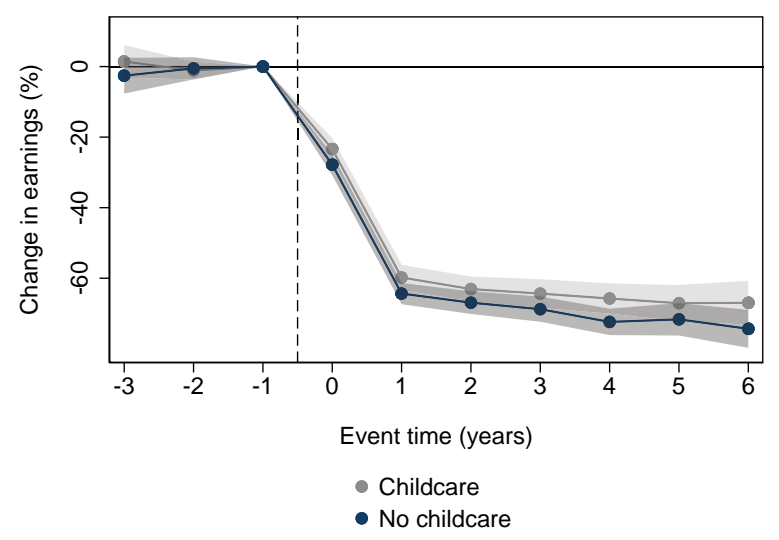

(b) Effect of childcare

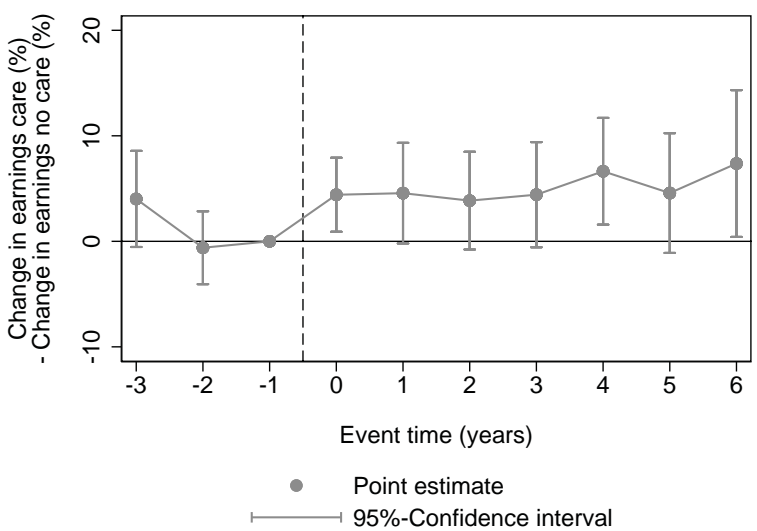

Note: Percentage effect of parenthood on female earnings relative to the year prior to the birth of the first child $(t=-1)$ using only individuals whose first child is born within 3 years around the opening of the childcare facility. Confidence bounds are calculated at the 5 percent level applying a non-parametric bootstrap. The corresponding estimates can be found in column (4) of Table A.10 in Appendix A.

and after the introduction, it is less likely that any difference is driven by,for example, an attitudinal change brought about by the introduction.

The restriction to children born within three years around the opening of a childcare facility reduces the sample by about 50 percent. This is reflected in the larger confidence bands in Figure 9. Still, we see that childcare decreases the child penalty of women by about 7 percentage points. The effect is significant at the 5 percent level for most event time periods. More importantly, the effect is of similar magnitude as the one in our main sample.

\subsection{Placebo test}

We perform a placebo test to address concerns that we may not capture the effect of childcare introductions but some trend, or that our fixed effects strategy may not be able to control for potential confounders. The placebo test confirms that our estimation approach does not lead to significant estimates when no effect should exist, i.e., when no childcare has been introduced. We use the sample of individuals living in municipalities which do not have childcare facilities by the end of 2015 and randomly assign a childcare facility-opening year between 2001 and 2015 to each of the municipalities assuming a uniform distribution. We then apply Equation 3 to measure the effect of these placebo childcare facilities. Figure 10 displays the average result for 1,000 replications of the random assignment of opening dates. 
Figure 10: Placebo estimates of childcare for women

(a) Placebo estimates of parenthood

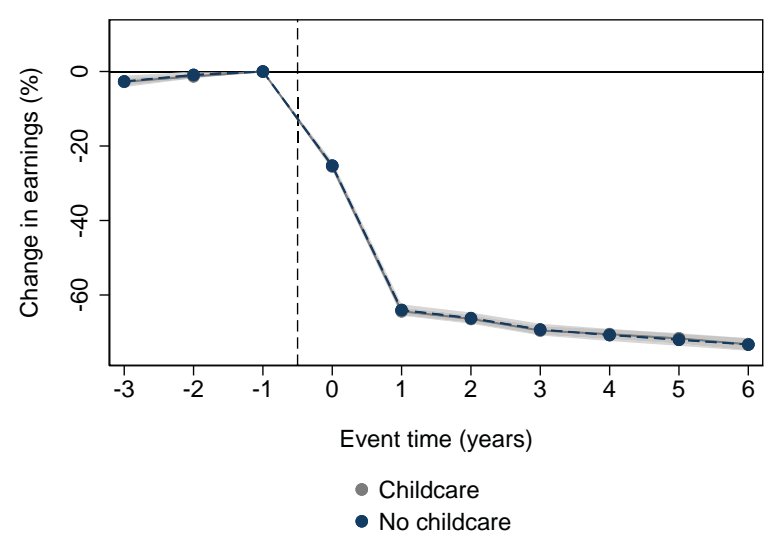

(b) Placebo childcare effect,

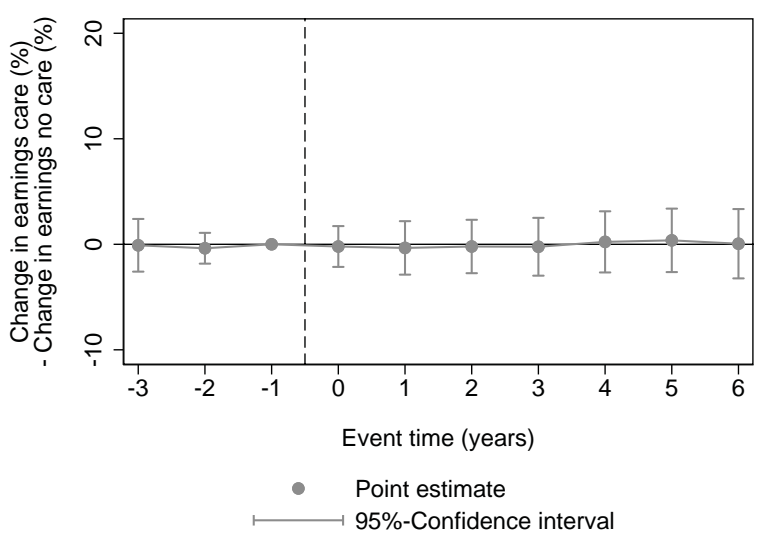

Note: Placebo effect of childcare. Percentage effect of parenthood on female earnings relative to the year prior to the birth of the first child $(t=-1)$ using only municipalities which do not have childcare facilities by the end of 2015 and randomly assigning opening dates for childcare facilities. Confidence bounds are drawn from the distributions of the placebo event time estimates. The corresponding estimates can be found in Figure A.3 in Appendix A.

We find no statistically significant difference between parents who, in the year of birth of their first child, live in a municipality randomly assigned with a childcare facility and parents living in a municipality without. This is clearly visible in panel (b) where we display the differential effect. The distributions of each of the event time estimates based on this random assignment is visualized in Figures A.3 and A.4 in the Appendix. In these graphs, we also compare the distribution of the placebo estimates to the point estimates in the upper right panel of Figure 3.

\subsection{Female breadwinners and the child penalty}

While we can show that the presence of childcare helps decrease the child penalty and increases female earnings shares, there is still a steep drop in female earnings after the birth of their first child, while male earnings show a slight increase. There are several arguments as to what drives the child penalty for women and why women's earnings respond more strongly than those of men. In this study, we demonstrate that formal institutions are an important determinant of the child penalty. While our findings suggest that childcare reduces the child penalty, childcare availability does in no way eliminate it. The large remaining (unexplained) drop in female earnings after childbirth leaves room for additional explanations. 
One popular argument is that the child penalty may emerge endogenously on efficiency grounds. ${ }^{27}$ Assuming that, typically, at least one parent needs to reduce labor supply to take care of the child and given that men earn more, on average, it may seem reasonable that the woman reduces her work hours in order to maximize household income given the constraint.

The efficiency argument can be put to a test by analyzing the child penalty depending on the female earnings share within a household. If the efficiency argument were to hold, households where the woman outearns her partner prior to the birth of their first child (female breadwinner) would show a smaller female child penalty than households where the man outearns the woman (male breadwinner). Appendix Figure A.5 and Table A.12 show a comparison of child penalties in couples with a female vs. couples with a male breadwinner. In the baseline specification, we define the breadwinner as the person who earns at least 50 percent of household earnings in the year before the birth of the first child. $^{28}$ Overall, slightly more than one fifth of all couples have a female breadwinner. We find that the child penalty for women in female-breadwinner couples is virtually indistinguishable from that of women in male-breadwinner couples. Except for the year of the child's birth itself, in which the female child penalty is slightly smaller if the woman was the breadwinner, there is no statistically significant difference between child penalties of women who were breadwinners and women who were not. The earnings of men, however, increase slightly more after the birth of the first child if their spouse was the breadwinner in the year before their child was born. This is consistent with the idea that he has to make up for a larger earnings drop. ${ }^{29}$ The results remain unchanged if we apply an alternative definition of the breadwinner of at least 60 percent of a couple's total earnings.

These findings suggest that gender norms play an important role in the explanation of the large part of the child penalty unaffected by childcare institutions. This is consistent with Kleven et al. (2019b), who present evidence showing a correlation between the child penalty and gender norms. If gender norms are a major driver of the child penalty, then we would not expect relative earnings contributions within the household to be related to the child penalty.

\footnotetext{
${ }^{27}$ One further argument is that biological costs related to child bearing might drive part of the earnings drop. Recent work by Kleven et al. (2020), however, finds no evidence for differences in child penalties between biological and adopted children.

${ }^{28}$ In order to achieve a reasonable sample size for this additional analysis, we use all couples in our data in this analysis. We do not restrict the sample to those municipalities that opened childcare facilities between years 2001 and 2015 .

${ }^{29}$ Note that the earnings of both women and men increase more steeply in the pre-birth period than earnings of non-breadwinners. Such slight pre-trends also appear in studies for other countries, see e.g. Kleven et al. (2019a) and Bütikofer et al. (2018). They probably reflect that for some groups, especially well educated individuals, earnings increase steeply in the 3 to 5 years before the birth of their first child, which usually coincides with the end of their education and subsequent employment. This is also reflected by the fact that we see the largest increases in pre-child earnings for higher-earnings families and that they are more pronounced for women. For lower-earnings families, many of whom probably finished their education longer before having a child, year and age effects are able to fully capture earnings trajectories, as seen in column (4) of Appendix Tables A.2 and A.3.
} 


\section{Conclusion}

We study the impact of the provision of formal childcare, one of the most widely used family policies to increase women's labor market attachment. We propose that childcare availability in the year the first child is born is particularly relevant for the development of parental earnings trajectories. We leverage the recently proposed event study approach estimating the effect of a first child on parents' labor market outcomes, the child penalty, to evaluate the differential effect of the availability of formal childcare.

Our empirical study draws on administrative data for the canton of Bern, one of the largest Swiss cantons. Bern is particularly interesting as it underwent a considerable expansion in the availability of formal childcare at the municipality level, from 6.4 to 24.2 percent of municipalities, between 2001 and 2015. We find that the observed child penalty in earnings for mothers, which amounts to about 70 percent, is comparable to estimates found for other countries. The introduction of childcare reduces the child penalty for women by about 4.5 percentage points (by 6.3 percent). This effect is primarily driven by an even stronger reduction in the child penalty of women in lower-earnings households (11.2 percentage points or 15.1 percent), and by subsidized childcare.

In line with previous literature, we find that men's earnings respond much less to the birth of the first child than women's earnings. However, we find that while male earnings generally increase after the birth of their first child, the increase is lower in the presence of childcare. This effect is particularly relevant for households in the lower part of the earnings distribution. This result suggests that the burden for men to make up for the drop in their partner's earnings is considerable in lower-earnings households. The availability of childcare seems to reduce this burden on fathers in lower-earnings households. It attenuates the increase in their earnings by 8.4 percentage points.

Our results contribute to the growing literature on the effect of children on parents' earnings trajectories and expand it by rendering causal estimates of childcare on parents labor market outcomes in an early phase of parenthood, just after the birth of a child. While the availability of childcare increases the labor market attachment of (especially lower-earnings) mothers, and thus the distribution of earnings within a household, we do not find an impact on total earnings at the household level. Childcare does not reduce the drop in total household earnings (of about 20 percent) related to the birth of the first child, but the composition of earnings between mothers and fathers. According to our findings for Switzerland, formal childcare does not seem to be a policy tool which could improve total earnings at the household level. However, it seems to be effective in increasing the labor market attachment of mothers, which is a second frequently mentioned goal of formal childcare. In addition, childcare reduces the burden on new fathers in households with below median earnings who otherwise have to make up for the drop in female earnings. This constitutes relaxing effect on a so far ignored but potentially important stress factor. 


\section{References}

Angelov, Nikolay, Per Johansson, and Erica Lindahl, "Parenthood and the gender gap in pay," Journal of Labor Economics, 2016, 34 (3), 545-579.

Bauernschuster, Stefan and Martin Schlotter, "Public child care and mothers' labor supply_Evidence from two quasi-experiments," Journal of Public Economics, 2015, 123, 1-16.

Blau, David, "Child care subsidy programs," in Robert A. Moffitt, ed., Means-tested transfer programs in the United States, University of Chicago Press, 2003, pp. 443-516.

- and Janet Currie, "Pre-school, day care, and after-school care: who's minding the kids?," Handbook of the Economics of Education, 2006, 2, 1163-1278.

Bönke, Timm, Ulrich Glogowsky, Emanuel Hansen, Holger Lüthen, and Dominik Sachs, "Family Policies and Child-Related Earnings Gaps in Germany," Mimeo, Free University of Berlin 2019.

Bütikofer, Aline, Sissel Jensen, and Kjell G Salvanes, "The role of parenthood on the gender gap among top earners," European Economic Review, 2018, 109, 103-123.

Cascio, Elizabeth U, "Maternal labor supply and the introduction of kindergartens into American public schools," Journal of Human Resources, 2009, 44 (1), 140-170.

- and Diane Whitmore Schanzenbach, "The Impacts of Expanding Access to HighQuality Preschool Education/Comments and Discussion," Brookings Papers on Economic Activity, 2013, p. 127.

Gelbach, Jonah B, "Public schooling for young children and maternal labor supply," American Economic Review, 2002, 92 (1), 307-322.

Girsberger, Esther Mirjam, Lena Hassani-Nezhad, Kalaivani Karunanethy, and Rafael Lalive, "Mothers at Work in Switzerland: Impact of First Paid Maternity Leave on Mothers' Employment and Earnings," Mimeo, University of Lausanne 2019.

Givord, Pauline and Claire Marbot, "Does the cost of child care affect female labor market participation? An evaluation of a French reform of childcare subsidies," Labour Economics, 2015, 36, 99-111.

Goldin, Claudia, "The quiet revolution that transformed women's employment, education, and family," American Economic Review, 2006, 96 (2), 1-21.

_ , "A grand gender convergence: Its last chapter," American Economic Review, 2014, 104 (4), 1091-1119. 
- and Joshua Mitchell, "The new life cycle of women's employment: Disappearing humps, sagging middles, expanding tops," Journal of Economic Perspectives, 2017, 31 (1), 161-82.

_ , Sari Pekkala Kerr, Claudia Olivetti, and Erling Barth, "The expanding gender earnings gap: Evidence from the LEHD-2000 Census," American Economic Review, 2017, 107 (5), 110-14.

Goux, Dominique and Eric Maurin, "Public school availability for two-year olds and mothers' labour supply," Labour Economics, 2010, 17 (6), 951-962.

Haeck, Catherine, Pierre Lefebvre, and Philip Merrigan, "Canadian evidence on ten years of universal preschool policies: The good and the bad," Labour Economics, 2015, 36, 137-157.

Havnes, Tarjei and Magne Mogstad, "Money for nothing? Universal child care and maternal employment," Journal of Public Economics, 2011, 95 (11-12), 1455-1465.

Kleven, Henrik, Camille Landais, and Jakob Egholt Søgaard, "Children and Gender Inequality: Evidence from Denmark," American Economic Journal: Applied Economics, 2019a, 11 (4), 181-209.

_, _, and _, "Does Biology Drive Child Penalties? Evidence from Biological and Adoptive Families," Working Paper 27130, National Bureau of Economic Research 2020.

_, _, Johanna Posch, Andreas Steinhauer, and Josef Zweimüller, "Child Penalties Across Countries: Evidence and Explanations," AEA Papers and Proceedings, 2019b, 109, 122-26.

Lefebvre, Pierre and Philip Merrigan, "Child-care policy and the labor supply of mothers with young children: A natural experiment from Canada," Journal of Labor Economics, 2008, 26 (3), 519-548.

_ , _ , and Matthieu Verstraete, "Dynamic labour supply effects of childcare subsidies: Evidence from a Canadian natural experiment on low-fee universal child care," Labour Economics, 2009, 16 (5), 490-502.

Lundin, Daniela, Eva Mörk, and Björn Öckert, "How far can reduced childcare prices push female labour supply?," Labour Economics, 2008, 15 (4), 647-659.

Müller, Kai-Uwe and Katharina Wrohlich, "Does subsidized care for toddlers increase maternal labor supply?," Labour Economics, 2020, 62 (5), 101776.

Nollenberger, Natalia and Núria Rodríguez-Planas, "Full-time universal childcare in a context of low maternal employment: Quasi-experimental evidence from Spain," Labour Economics, 2015, 36, 124-136. 
Olivetti, Claudia and Barbara Petrongolo, "The Economic Consequences of Family Policies: Lessons from a Century of Legislation in High-Income Countries," Journal of Economic Perspectives, 2017, 31 (1), 205-230.

Schmidheiny, Kurt and Sebastian Siegloch, "On Event Study Designs and Distributed-Lag Models: Equivalence, Generalization and Practical Implications," Discussion Paper 13477, C.E.P.R. January 2019. 


\section{A Appendix}

Table A.1: Descriptive statistics

\begin{tabular}{|c|c|c|c|c|c|c|c|c|c|c|c|c|}
\hline & \multicolumn{4}{|c|}{ Main sample: childcare } & \multicolumn{4}{|c|}{ Intro post 2015} & \multicolumn{2}{|c|}{ Intro pre 2001} & \multicolumn{2}{|c|}{ Intro undeterm. } \\
\hline & Mean & S.D. & Min. & Max. & Mean & S.D. & $\Delta$ mean & p-val & Mean & S.D. & Mean & S.D. \\
\hline Earnings women $(\mathrm{t}=-1)$ & 51,113 & 21,188 & 0 & 232,005 & 51,077 & 18,941 & 36 & 0.95 & 51,490 & 23,501 & 53,595 & 23,123 \\
\hline Earnings men $(t=-1)$ & 69,601 & 27,342 & 0 & 330,532 & 67,613 & 24,123 & 1,987 & 0.01 & 69,107 & 31,619 & 73,263 & 35,232 \\
\hline Age women $(\mathrm{t}=-1)$ & 29.43 & 4.10 & 21 & 42 & 29.54 & 4.10 & -0.11 & 0.35 & 29.87 & 4.10 & 30.05 & 4.10 \\
\hline Age men $(t=-1)$ & 31.95 & 4.43 & 21 & 42 & 32.11 & 4.42 & -0.16 & 0.22 & 32.16 & 4.45 & 32.27 & 4.34 \\
\hline Married ( $\mathrm{t}=-1)$ & 0.71 & 0.45 & 0 & 1 & 0.71 & 0.45 & -0.00 & 0.90 & 0.68 & 0.47 & 0.69 & 0.46 \\
\hline Number of children $(t=3)$ & 1.74 & 0.51 & 1 & 4 & 1.75 & 0.51 & -0.01 & 0.74 & 1.68 & 0.53 & 1.67 & 0.53 \\
\hline Number of children $(t=5)$ & 2.00 & 0.58 & 1 & 4 & 1.99 & 0.60 & 0.00 & 0.88 & 1.94 & 0.59 & 1.92 & 0.59 \\
\hline $\mathrm{N}$ couples & \multicolumn{4}{|c|}{1,959} & \multicolumn{4}{|c|}{3,020} & \multicolumn{2}{|c|}{3,692} & \multicolumn{2}{|c|}{1,701} \\
\hline
\end{tabular}

Notes: The left-hand panel displays information for couples from our main analysis who live in municipalities that introduce childcare between 2001 and 2015. The middle panel displays corresponding figures for couples in municipalities which did not have childcare by the end of 2015. The right-hand panel displays the figures for couples in municipalities which opened a childcare facility before 2001. Earnings are in Swiss francs.

Table A.1 shows descriptive statistics. Men's earnings in the year before they have their first child are higher, on average, than those of their female partners. ${ }^{30}$ They are, however, on average also more than 2.5 years older in that year. 71 percent of couples in our analysis are married in the year before childbirth. The number of children increases to on average 1.74 three years after birth of the first child, and to 2 children five years after. The central panel displays corresponding numbers for couples living in municipalities which did not have childcare by the end of 2015. We use those for placebo tests. The summary statistics are hardly distinguishable for the two groups. Only mean male earnings differ significantly between the two groups with a $t$-statistic of 2.69 .

The third panel shows summary statistics for couples who had their first child in municipalities which introduced institutional childcare already before 2001. These municipalities include the urban centers of Bern and Biel. The fourth panel, finally, shows descriptive statistics for couples in municipalities for which we were not able to determine the date of childcare introduction. We do not use observations from the latter two groups in any part of our analysis. Mean numbers for most non-monetary characteristics of these groups differ significantly from the means in our main sample. Earnings tend to be slightly higher among couples in municipalities with childcare before 2001 or with an undetermined year of introduction. As one might expect, couples in more urban areas tend to be slightly older and less likely to be married in the year before the birth of their first child. They also tend to have fewer children 3 and 5 years after the birth of their first child.

\footnotetext{
${ }^{30}$ Earnings are displayed in Swiss francs. 1 Swiss franc corresponded to $\$ 1.10$ on August $6,2020$.
} 
Table A.2: Earnings penalty, women

\begin{tabular}{|c|c|c|c|c|c|}
\hline & Overall & Childcare & $\begin{array}{l}\text { Childcare \& } \\
\text { Hh inc. }>\text { p50 }\end{array}$ & $\begin{array}{l}\text { Childcare \& } \\
\text { Hh inc. } \leq \text { p50 }\end{array}$ & $\begin{array}{l}\text { Subsidized } \\
\text { childcare }\end{array}$ \\
\hline & (1) & $(2)$ & (3) & $(4)$ & (5) \\
\hline Event -3 & $\begin{array}{l}-0.015 \\
(0.014)\end{array}$ & $\begin{array}{l}-0.016 \\
(0.018)\end{array}$ & $\begin{array}{r}-0.041^{* *} \\
(0.020)\end{array}$ & $\begin{array}{r}0.016 \\
(0.031)\end{array}$ & $\begin{array}{r}-0.020 \\
(0.018)\end{array}$ \\
\hline Event -2 & $\begin{array}{r}-0.013^{*} \\
(0.007)\end{array}$ & $\begin{array}{r}-0.008 \\
(0.010)\end{array}$ & $\begin{array}{r}-0.022^{*} \\
(0.012)\end{array}$ & $\begin{array}{r}0.018 \\
(0.016)\end{array}$ & $\begin{array}{r}-0.010 \\
(0.009)\end{array}$ \\
\hline Event 0 & $-0.243^{* * *}$ & $-0.259^{* * *}$ & $-0.226^{* * *}$ & $-0.304^{* * *}$ & $-0.261^{* * *}$ \\
\hline Event +1 & $\begin{array}{r}(0.009) \\
-0.620^{* * *}\end{array}$ & $\begin{array}{r}(0.011) \\
-0.642^{* * *}\end{array}$ & $\begin{array}{r}(0.014) \\
-0.623^{* * *}\end{array}$ & $\begin{array}{r}(0.016) \\
-0.681^{* * *}\end{array}$ & $\begin{array}{r}(0.011) \\
-0.653^{* * *}\end{array}$ \\
\hline & $(0.008)$ & (0.011) & $(0.013)$ & $(0.017)$ & $(0.012)$ \\
\hline Event +2 & $\begin{array}{r}-0.641^{* * *} \\
(0.008)\end{array}$ & $\begin{array}{r}-0.661^{* * * *} \\
(0.011)\end{array}$ & $\begin{array}{r}-0.653^{* * *} \\
(0.013)\end{array}$ & $\begin{array}{r}-0.686^{* * *} \\
(0.017)\end{array}$ & $\begin{array}{r}-0.671^{* * *} \\
(0.012)\end{array}$ \\
\hline Event +3 & $\begin{array}{r}-0.672^{* * *} \\
(0.009)\end{array}$ & $\begin{array}{r}-0.687^{* * * *} \\
(0.012)\end{array}$ & $\begin{array}{r}-0.676^{* * *} \\
(0.014)\end{array}$ & $\begin{array}{r}-0.718^{* * *} \\
(0.018)\end{array}$ & $\begin{array}{r}-0.694^{* * *} \\
(0.013)\end{array}$ \\
\hline Event +4 & $\begin{array}{r}-0.684^{* * *} \\
(0.010)\end{array}$ & $\begin{array}{r}-0.701 * * * \\
(0.013)\end{array}$ & $\begin{array}{r}-0.686^{* * * *} \\
(0.015)\end{array}$ & $\begin{array}{r}-0.734^{* * * *} \\
(0.021)\end{array}$ & $\begin{array}{r}-0.706^{* * *} \\
(0.014)\end{array}$ \\
\hline Event +5 & $\begin{array}{r}-0.691^{* * *} * \\
(0.012)\end{array}$ & $-0.707^{* * *}$ & $-0.687^{* * *}$ & $-0.747^{* * *}$ & $-0.714^{* * *}$ \\
\hline Event +6 & $-0.692^{* * *}$ & $-0.714^{* * *}$ & $-0.702^{* * *}$ & $-0.744^{* * *}$ & $\begin{array}{r}(0.015) \\
-0.718^{* * *}\end{array}$ \\
\hline Event $-3 \cdot$ care & $(0.014)$ & $\begin{array}{r}(0.016) \\
0.007 \\
(0.016)\end{array}$ & $\begin{array}{r}(0.019) \\
0.014 \\
(0.016)\end{array}$ & $\begin{array}{r}(0.027) \\
0.007 \\
(0.030)\end{array}$ & $\begin{array}{r}(0.017) \\
0.012 \\
(0.033)\end{array}$ \\
\hline Event $-2 \cdot$ care & & $\begin{array}{l}-0.007 \\
(0.011)\end{array}$ & $\begin{array}{r}0.001 \\
(0.012)\end{array}$ & $\begin{array}{r}-0.021 \\
(0.019)\end{array}$ & 0.000 \\
\hline Event $0 \cdot$ care & & $\begin{array}{r}0.026^{* *} \\
(0.011)\end{array}$ & $\begin{array}{l}0.028^{*} \\
(0.014)\end{array}$ & $\begin{array}{r}0.029^{*} \\
(0.018)\end{array}$ & $0.043^{*}$ \\
\hline Event $+1 \cdot$ care & & $\begin{array}{r}0.038^{* *} \\
(0.015)\end{array}$ & $\begin{array}{r}0.030^{*} \\
(0.018)\end{array}$ & $\begin{array}{r}0.067^{* * *} \\
(0.024)\end{array}$ & 0.013 \\
\hline Event $+2 \cdot$ care & & $0.035^{* *}$ & $\begin{array}{r}0.024 \\
(0.018)\end{array}$ & $\begin{array}{r}0.074^{* * *} \\
(0.025)\end{array}$ & $\begin{array}{r}0.018 \\
(0.034)\end{array}$ \\
\hline Event +3 care & & $\begin{array}{r}0.026 \\
(0.016)\end{array}$ & $\begin{array}{r}0.009 \\
(0.019)\end{array}$ & $\begin{array}{r}0.086^{* * *} \\
(0.026)\end{array}$ & $\begin{array}{r}0.001 \\
(0.036)\end{array}$ \\
\hline Event +4 . care & & $\begin{array}{l}0.031^{*} \\
(0.017)\end{array}$ & $\begin{array}{r}0.008 \\
(0.020)\end{array}$ & $\begin{array}{r}0.099^{* * *} \\
(0.028)\end{array}$ & $\begin{array}{r}0.013 \\
(0.038)\end{array}$ \\
\hline Event $+5 \cdot$ care & & $\begin{array}{r}0.032^{*} \\
(0.019)\end{array}$ & $\begin{array}{r}0.002 \\
(0.022)\end{array}$ & $\begin{array}{r}0.105^{* * *} \\
(0.031)\end{array}$ & $\begin{array}{r}0.026 \\
(0.042)\end{array}$ \\
\hline Event $+6 \cdot$ care & & $0.045^{* *}$ & 0.019 & $0.112^{* * *}$ & 0.022 \\
\hline Event $-3 \cdot$ subs. care & & $(0.023)$ & $(0.026)$ & $(0.034)$ & 0.018 \\
\hline Event $-2 \cdot$ subs. care & & & & & $\begin{array}{l}-0.002 \\
(0.011)\end{array}$ \\
\hline Event $0 \cdot$ subs. care & & & & & $\begin{array}{r}0.028^{* *} \\
(0.012)\end{array}$ \\
\hline Event +1 . subs. care & & & & & $\begin{array}{r}0.050^{* * *} \\
(0.016)\end{array}$ \\
\hline Event $+2 \cdot$ subs. care & & & & & $\begin{array}{r}0.045^{* * *} \\
(0.016)\end{array}$ \\
\hline Event +3 . subs. care & & & & & $\begin{array}{r}0.034^{* *} \\
(0.017)\end{array}$ \\
\hline Event +4 . subs. care & & & & & $\begin{array}{r}0.040^{* *} \\
(0.018)\end{array}$ \\
\hline Event $+5 \cdot$ subs. care & & & & & $\begin{array}{r}0.042^{* *} \\
(0.020)\end{array}$ \\
\hline Event +6 . subs. care & & & & & $\begin{array}{r}0.056^{* *} \\
(0.024)\end{array}$ \\
\hline Tndiv. FE & Yes & Yes & Yes & Yes & Yes \\
\hline Year FE & Yes & Yes & Yes & Yes & Yes \\
\hline Age FE & $\begin{array}{l}\text { Yes } \\
\text { Yes }\end{array}$ & $\begin{array}{l}\text { Yes } \\
\text { Yes }\end{array}$ & $\begin{array}{l}\text { Yes } \\
\text { Yes }\end{array}$ & $\begin{array}{l}\text { Yes } \\
\text { Yes }\end{array}$ & Yes \\
\hline $\begin{array}{l}\text { Married }(\mathrm{t}<0) \\
\mathrm{N} \text { indiv. }\end{array}$ & $\begin{array}{r}\text { Yes } \\
1959\end{array}$ & $\begin{array}{r}\text { Yes } \\
1959\end{array}$ & $\begin{array}{r}\text { Yes } \\
1001\end{array}$ & $\begin{array}{l}\text { Yes } \\
958\end{array}$ & $\begin{array}{r}\text { Yes } \\
1767\end{array}$ \\
\hline $\mathrm{N}$ & 21437 & 21437 & 11194 & 10243 & 19359 \\
\hline
\end{tabular}

Notes: Event study estimates of female earnings relative to the year prior to the birth of their first child. The interaction terms with childcare (care) indicate the differential effect if at the birth of the first child, there are childcare facilities in the municipality of residence. The interaction terms with subsidized childcare (subs. care) indicate the difference if at the birth of the first child, there are subsidized childcare facilities in the municipality of residence compared to if there is no childcare. Standard errors are bootstrapped (1000 replications) as the estimates of earnings changes are transformed into percentage changes after the estimation by dividing the estimates by earnings, i.e. predicted earnings when setting event time dummies to zero.

Significance levels: ${ }^{*} \mathrm{p}<0.10,{ }^{* *} \mathrm{p}<0.05,{ }^{* * *} \mathrm{p}<0.01$. 
Table A.3: Earnings penalty, men

\begin{tabular}{|c|c|c|c|c|c|}
\hline & Overall & Childcare & $\begin{array}{l}\text { Childcare \& } \\
\text { Hh inc. }>\text { p50 }\end{array}$ & $\begin{array}{l}\text { Childcare \& } \\
\text { Hh inc. } \leq \text { p50 }\end{array}$ & $\begin{array}{l}\text { Subsidized } \\
\text { childcare }\end{array}$ \\
\hline & (1) & (2) & (3) & (4) & (5) \\
\hline Event -3 & $\begin{array}{l}-0.018 \\
(0.015)\end{array}$ & $\begin{array}{r}-0.020 \\
(0.018)\end{array}$ & $\begin{array}{r}-0.051^{* *} \\
(0.021)\end{array}$ & $\begin{array}{r}0.027 \\
(0.029)\end{array}$ & $\begin{array}{l}-0.013 \\
(0.019)\end{array}$ \\
\hline Event -2 & $\begin{array}{r}-0.012^{*} \\
(0.007)\end{array}$ & $\begin{array}{r}-0.012 \\
(0.009)\end{array}$ & $\begin{array}{r}-0.022^{*} \\
(0.012)\end{array}$ & $\begin{array}{l}(0.029) \\
-0.001 \\
(0.015)\end{array}$ & $\begin{array}{r}(0.019) \\
-0.006 \\
(0.010)\end{array}$ \\
\hline Event 0 & $\begin{array}{r}0.045^{* * *} \\
(0.010)\end{array}$ & $\begin{array}{r}0.050^{* * *} \\
(0.011)\end{array}$ & $\begin{array}{r}0.011 \\
(0.015)\end{array}$ & $0.096^{* * *}$ & $0.046^{* * *}$ \\
\hline Event +1 & $\begin{array}{r}0.054^{* * *} \\
(0.012)\end{array}$ & $\begin{array}{r}0.066^{* * *} \\
(0.014)\end{array}$ & $\begin{array}{r}(0.015) \\
0.020 \\
(0.019)\end{array}$ & $\begin{array}{r}0.129 * * * \\
(0.025)\end{array}$ & $\begin{array}{r}0.062^{* * * *} \\
(0.015)\end{array}$ \\
\hline Event +2 & $\begin{array}{r}0.054^{* * *} * \\
(0.014)\end{array}$ & $\begin{array}{r}0.068^{* * *} \\
(0.016)\end{array}$ & $\begin{array}{r}0.021 \\
(0.021)\end{array}$ & $\begin{array}{r}0.136^{* * *} \\
(0.029)\end{array}$ & $\begin{array}{r}0.062^{* * *} \\
(0.017)\end{array}$ \\
\hline Event +3 & $\begin{array}{r}0.073^{* * *} \\
(0.017)\end{array}$ & $\begin{array}{r}0.087^{* * *} \\
(0.019)\end{array}$ & $\begin{array}{r}0.027 \\
(0.025)\end{array}$ & $\begin{array}{r}0.183^{* * *} \\
(0.036)\end{array}$ & $\begin{array}{r}0.081^{* * * *} \\
(0.021)\end{array}$ \\
\hline Event +4 & $\begin{array}{r}0.069^{* * *} \\
(0.020)\end{array}$ & $\begin{array}{r}0.077^{* * *} \\
(0.022)\end{array}$ & $\begin{array}{r}0.008 \\
(0.028)\end{array}$ & $\begin{array}{r}0.191^{* * *} \\
(0.040)\end{array}$ & $\begin{array}{r}0.073^{* * *} \\
(0.024)\end{array}$ \\
\hline Event +5 & $\begin{array}{r}0.065^{* * *} \\
(0.023)\end{array}$ & $\begin{array}{r}0.082^{* * *} * \\
(0.024)\end{array}$ & $\begin{array}{r}0.017 \\
(0.030)\end{array}$ & $\begin{array}{r}0.194^{* * *} \\
(0.042)\end{array}$ & $\begin{array}{r}0.075^{* * *} \\
(0.026)\end{array}$ \\
\hline Event +6 & $\begin{array}{r}0.057^{* *} \\
(0.026)\end{array}$ & $\begin{array}{r}0.076^{* * *} \\
(0.027)\end{array}$ & 0.001 & $0.215^{* * *}$ & $0.069^{* *}$ \\
\hline Event $-3 \cdot$ care & & -0.001 & 0.017 & -0.017 & $\begin{array}{r}(0.030) \\
0.010\end{array}$ \\
\hline Event $-2 \cdot$ care & & $\begin{array}{r}(0.015) \\
-0.001\end{array}$ & $\begin{array}{r}(0.017) \\
-0.003\end{array}$ & $\begin{array}{r}(0.023) \\
0.007\end{array}$ & $\begin{array}{r}(0.028) \\
0.011\end{array}$ \\
\hline Event $0 \cdot$ care & & $\begin{array}{l}(0.010) \\
-0.007\end{array}$ & $\begin{array}{l}(0.013) \\
-0.003\end{array}$ & $\begin{array}{l}(0.015) \\
-0.012\end{array}$ & $\begin{array}{l}(0.018) \\
-0.018\end{array}$ \\
\hline Event $+1 \cdot$ care & & $\begin{array}{c}(0.008) \\
-0.019^{*} \\
(0.011)\end{array}$ & $\begin{array}{l}(0.011) \\
-0.021 \\
(0.014)\end{array}$ & $\begin{array}{r}(0.013) \\
-0.017 \\
(0.017)\end{array}$ & $\begin{array}{r}(0.019) \\
-0.017 \\
(0.025)\end{array}$ \\
\hline Event $+2 \cdot$ care & & $\begin{array}{r}-0.022^{*} \\
(0.012)\end{array}$ & $\begin{array}{r}-0.022 \\
(0.014)\end{array}$ & $\begin{array}{l}-0.024 \\
(0.019)\end{array}$ & $\begin{array}{l}-0.014 \\
(0.030)\end{array}$ \\
\hline Event $+3 \cdot$ care & & $-0.024^{*}$ & -0.017 & $-0.044^{*}$ & -0.014 \\
\hline Event $+4 \cdot$ care & & & & $\begin{array}{r}(0.024) \\
-0.025\end{array}$ & $\begin{array}{l}(0.023) \\
-0.006\end{array}$ \\
\hline Event $+5 \cdot$ care & & $\begin{array}{r}(0.016) \\
-0.031^{*} \\
(0.018)\end{array}$ & $\begin{array}{l}(0.018) \\
-0.035^{*}\end{array}$ & $\begin{array}{r}(0.028) \\
-0.030\end{array}$ & $\begin{array}{l}(0.029) \\
-0.021\end{array}$ \\
\hline Event $+6 \cdot$ care & & $\begin{array}{l}(0.018) \\
-0.037^{*} \\
(0.021)\end{array}$ & $\begin{array}{l}(0.021) \\
-0.017 \\
(0.024)\end{array}$ & $\begin{array}{r}(0.030) \\
-0.084^{* *} \\
(0.037)\end{array}$ & $\begin{array}{r}(0.034) \\
-0.067^{*} \\
(0.037)\end{array}$ \\
\hline Event $-3 \cdot$ subs. care & & & & & $\begin{array}{l}-0.008 \\
(0.016)\end{array}$ \\
\hline Event $-2 \cdot$ subs. care & & & & & -0.010 \\
\hline Event 0 . subs. care & & & & & $\begin{array}{l}(0.011) \\
-0.003\end{array}$ \\
\hline Event +1 . subs. care & & & & & $\begin{array}{r}(0.008) \\
-0.017 \\
(0.012)\end{array}$ \\
\hline Event $+2 \cdot$ subs. care & & & & & $\begin{array}{l}-0.022^{*} \\
(0.012)\end{array}$ \\
\hline Event +3 . subs. care & & & & & -0.023 \\
\hline Event +4 . subs. care & & & & & $\begin{array}{l}(0.014) \\
-0.017 \\
(0.017)\end{array}$ \\
\hline Event +5 . subs. care & & & & & $\begin{array}{r}-0.035^{*} \\
(0.019)\end{array}$ \\
\hline Event $+6 \cdot$ subs. care & & & & & $\begin{array}{r}-0.034 \\
(0.023) \\
\end{array}$ \\
\hline Indiv. FE & Yes & Yes & Yes & Yes & Yes \\
\hline Year FE & Yes & Yes & Yes & Yes & Yes \\
\hline Age FE & Yes & Yes & Yes & Yes & Yes \\
\hline Married $(\mathrm{t}<0)$ & Yes & Yes & Yes & Yes & Yes \\
\hline $\mathrm{N}$ indiv. & 1959 & 1959 & 1001 & 958 & 1767 \\
\hline $\mathrm{N}$ & 21437 & 21437 & 11194 & 10243 & 19359 \\
\hline
\end{tabular}

Notes: Event study estimates of male earnings relative to the year prior to the birth of their first child. The interaction terms with childcare (care) indicate the differential effect if at the birth of the first child, there are childcare facilities in the municipality of residence. The interaction terms with subsidized childcare (subs. care) indicate the difference if at the birth of the first child, there are subsidized childcare facilities in the municipality of residence compared to if there is no childcare. Standard errors are bootstrapped (1000 replications) as the estimates of earnings changes are transformed into percentage changes after the estimation by dividing the estimates by earnings, i.e. predicted earnings when setting event time dummies to zero.

Significance levels: $* \mathrm{p}<0.10,{ }^{* *} \mathrm{p}<0.05, * * * \mathrm{p}<0.01$. 
Table A.4: Participation penalty, women

\begin{tabular}{|c|c|c|c|c|c|}
\hline & Overall & Childcare & $\begin{array}{l}\text { Childcare \& } \\
\text { Hh inc.>p50 }\end{array}$ & $\begin{array}{l}\text { Childcare \& } \\
\text { Hh inc. } \leq \text { p50 }\end{array}$ & $\begin{array}{c}\text { Subsidized } \\
\text { childcare }\end{array}$ \\
\hline & $(1)$ & $(2)$ & (3) & $(4)$ & $(5)$ \\
\hline \multirow[t]{2}{*}{ Event -3} & -0.000 & -0.002 & 0.011 & -0.010 & -0.006 \\
\hline & $(0.012)$ & $(0.012)$ & $(0.014)$ & $(0.020)$ & $(0.012)$ \\
\hline \multirow[t]{2}{*}{ Event -2} & -0.010 & -0.004 & 0.002 & -0.007 & -0.005 \\
\hline & $(0.006)$ & $(0.006)$ & $(0.007)$ & (0.011) & $(0.007)$ \\
\hline \multirow[t]{2}{*}{ Event 0} & $-0.022^{* *}$ & $-0.027^{* *}$ & -0.013 & $-0.046^{* * *}$ & $-0.019^{*}$ \\
\hline & (0.009) & $(0.010)$ & $(0.012)$ & (0.017) & (0.011) \\
\hline \multirow[t]{2}{*}{ Event +1} & $-0.145^{* * *}$ & $-0.159^{* * *}$ & $-0.129 * * *$ & $-0.195^{* * *}$ & $-0.155^{* * *}$ \\
\hline & $(0.014)$ & (0.017) & $(0.022)$ & (0.027) & $(0.018)$ \\
\hline \multirow[t]{2}{*}{ Event +2} & $-0.184^{* * *}$ & $-0.201^{* * *}$ & $-0.195^{* * *}$ & $-0.217^{* * *}$ & $-0.195 * * *$ \\
\hline & (0.017) & $(0.020)$ & (0.026) & (0.031) & (0.021) \\
\hline \multirow[t]{2}{*}{ Event +3} & $-0.195^{* * *}$ & $-0.215^{* * *}$ & $-0.216^{* * *}$ & $-0.226^{* * *}$ & $-0.208^{* * * *}$ \\
\hline & $(0.020)$ & $(0.023)$ & (0.030) & $(0.036)$ & $(0.024)$ \\
\hline \multirow[t]{2}{*}{ Event +4} & $-0.207^{* * *}$ & $-0.223^{* * *}$ & $-0.227^{* * *}$ & $-0.235^{* * *}$ & $-0.213^{* * *}$ \\
\hline & (0.023) & $(0.026)$ & $(0.034)$ & $(0.042)$ & $(0.028)$ \\
\hline \multirow[t]{2}{*}{ Event +5} & $-0.213^{* * *}$ & $-0.225^{* * *}$ & $-0.229 * * *$ & $-0.239 * * *$ & $-0.211^{* * *}$ \\
\hline & (0.027) & $(0.030)$ & $(0.038)$ & $(0.048)$ & $(0.031)$ \\
\hline \multirow[t]{2}{*}{ Event +6} & $-0.207^{* * *}$ & $-0.233^{* * *}$ & $-0.244^{* * *}$ & $-0.239 * * *$ & $-0.221 * * *$ \\
\hline & $(0.031)$ & (0.034) & $(0.042)$ & $(0.055)$ & $(0.035)$ \\
\hline \multirow[t]{2}{*}{ Event $-3 \cdot$ care } & & 0.007 & 0.010 & 0.003 & 0.021 \\
\hline & & $(0.008)$ & $(0.008)$ & $(0.015)$ & $(0.018)$ \\
\hline \multirow[t]{2}{*}{ Event $-2 \cdot$ care } & & -0.009 & -0.003 & -0.015 & 0.003 \\
\hline & & $(0.008)$ & $(0.008)$ & $(0.015)$ & $(0.022)$ \\
\hline \multirow[t]{2}{*}{ Event $0 \cdot$ care } & & 0.006 & 0.002 & 0.009 & 0.015 \\
\hline & & $(0.008)$ & $(0.005)$ & $(0.015)$ & $(0.010)$ \\
\hline \multirow[t]{2}{*}{ Event $+1 \cdot$ care } & & 0.021 & 0.002 & 0.037 & $0.052^{*}$ \\
\hline & & $(0.017)$ & $(0.021)$ & $(0.026)$ & $(0.031)$ \\
\hline \multirow[t]{2}{*}{ Event $+2 \cdot$ care } & & 0.026 & 0.013 & 0.038 & 0.024 \\
\hline & & $(0.019)$ & $(0.025)$ & $(0.028)$ & $(0.038)$ \\
\hline \multirow[t]{2}{*}{ Event $+3 \cdot$ care } & & 0.032 & 0.014 & $0.048^{*}$ & 0.040 \\
\hline & & $(0.020)$ & $(0.026)$ & $(0.029)$ & $(0.039)$ \\
\hline \multirow[t]{2}{*}{ Event $+4 \cdot$ care } & & 0.026 & 0.012 & 0.040 & 0.007 \\
\hline & & $(0.021)$ & $(0.028)$ & $(0.032)$ & $(0.042)$ \\
\hline Event $+5 \cdot$ care & & 0.017 & -0.008 & 0.045 & 0.003 \\
\hline & & $(0.022)$ & $(0.030)$ & $(0.034)$ & $(0.043)$ \\
\hline Event $+6 \cdot$ care & & $0.051^{* *}$ & 0.015 & $0.089 * *$ & 0.055 \\
\hline & & $(0.023)$ & $(0.030)$ & $(0.036)$ & $(0.044)$ \\
\hline Event $-3 \cdot$ subs. care & & & & & $\begin{array}{r}-0.014 \\
(0.018)\end{array}$ \\
\hline Event $-2 \cdot$ subs. care & & & & & -0.010 \\
\hline & & & & & $(0.023)$ \\
\hline Event $0 \cdot$ subs. care & & & & & -0.012 \\
\hline & & & & & $(0.010)$ \\
\hline Event $+1 \cdot$ subs. care & & & & & -0.036 \\
\hline Event $+2 \cdot$ subs. care & & & & & $\begin{array}{r}(0.031) \\
0.001\end{array}$ \\
\hline cvent + 2 . sums. care & & & & & $(0.037)$ \\
\hline Event $+3 \cdot$ subs. care & & & & & -0.012 \\
\hline & & & & & $(0.039)$ \\
\hline Event $+4 \cdot$ subs. care & & & & & 0.021 \\
\hline & & & & & $(0.042)$ \\
\hline Event $+5 \cdot$ subs. care & & & & & 0.009 \\
\hline & & & & & $(0.043)$ \\
\hline Event $+6 \cdot$ subs. care & & & & & -0.007 \\
\hline & & & & & $(0.044)$ \\
\hline Indiv. FE & Yes & Yes & Yes & Yes & Yes \\
\hline Year FE & Yes & Yes & Yes & Yes & Yes \\
\hline Age FE & Yes & Yes & Yes & Yes & Yes \\
\hline Married $(\mathrm{t}<0)$ & Yes & Yes & Yes & Yes & Yes \\
\hline $\mathrm{N}$ indiv. & 1959 & 1959 & 1001 & 958 & 1767 \\
\hline $\mathrm{N}$ & 21437 & 21437 & 11194 & 10243 & 19359 \\
\hline
\end{tabular}

Notes: Event study estimates of female participation rates relative to the year prior to the birth of their first child. The interaction terms with childcare (care) indicate the differential effect if at the birth of the first child, there are childcare facilities in the municipality of residence. The interaction terms with subsidized childcare (subs. care) indicate the difference if at the birth of the first child, there are subsidized childcare facilities in the municipality of residence compared to if there is no childcare. Standard errors are bootstrapped (1000 replications) as the estimates of earnings changes are transformed into percentage changes after the estimation by dividing the estimates by earnings, i.e. predicted earnings when setting event time dummies to zero. Significance levels: ${ }^{*} \mathrm{p}<0.10,{ }^{* *} \mathrm{p}<0.05,{ }^{* * *} \mathrm{p}<0.01$. 
Table A.5: Participation penalty, men

\begin{tabular}{|c|c|c|c|c|c|}
\hline & Overall & Childcare & $\begin{array}{l}\text { Childcare \& } \\
\text { Hh inc. }>\text { p50 }\end{array}$ & $\begin{array}{l}\text { Childcare \& } \\
\text { Hh inc. } \leq \text { p50 }\end{array}$ & $\begin{array}{l}\text { Subsidized } \\
\text { childcare }\end{array}$ \\
\hline & (1) & $(2)$ & (3) & $(4)$ & (5) \\
\hline Event -3 & $\begin{array}{r}-0.012^{* *} \\
(0.006)\end{array}$ & $\begin{array}{l}-0.011 \\
(0.008)\end{array}$ & $\begin{array}{r}-0.006 \\
(0.009)\end{array}$ & $\begin{array}{r}-0.015 \\
(0.014)\end{array}$ & $\begin{array}{r}-0.008 \\
(0.008)\end{array}$ \\
\hline Event -2 & $\begin{array}{r}-0.008^{* *} \\
(0.004)\end{array}$ & $\begin{array}{r}-0.007 \\
(0.006)\end{array}$ & 0.001 & -0.016 & -0.006 \\
\hline Event 0 & $\begin{array}{r}0.001 \\
(0.004)\end{array}$ & $\begin{array}{r}0.002 \\
0.005)\end{array}$ & $\begin{array}{r}-0.003 \\
-0.005)\end{array}$ & $\begin{array}{r}0.009 \\
(0.009)\end{array}$ & $\begin{array}{r}0.002 \\
(0.006)\end{array}$ \\
\hline Event +1 & $\begin{array}{r}-0.007 \\
(0.006)\end{array}$ & $\begin{array}{l}-0.0005 \\
-0.005) \\
(0.007)\end{array}$ & $\begin{array}{r}(0.005) \\
-0.006 \\
(0.007)\end{array}$ & $\begin{array}{l}(0.009) \\
-0.001 \\
(0.012)\end{array}$ & $\begin{array}{r}(0.006) \\
-0.007 \\
(0.007)\end{array}$ \\
\hline Event +2 & $\begin{array}{r}-0.015^{* *} \\
(0.007)\end{array}$ & $\begin{array}{r}-0.012 \\
(0.008)\end{array}$ & $\begin{array}{r}-0.009 \\
(0.008)\end{array}$ & $\begin{array}{l}-0.011 \\
(0.013)\end{array}$ & $\begin{array}{l}-0.013^{*} \\
(0.008)\end{array}$ \\
\hline Event +3 & $\begin{array}{r}-0.015^{*} \\
(0.009)\end{array}$ & $\begin{array}{l}-0.013 \\
(0.009)\end{array}$ & $\begin{array}{l}-0.014 \\
(0.010)\end{array}$ & $\begin{array}{l}-0.007 \\
(0.016)\end{array}$ & $\begin{array}{l}-0.013 \\
(0.010)\end{array}$ \\
\hline Event +4 & $\begin{array}{r}-0.023^{* *} \\
(0.011)\end{array}$ & $\begin{array}{r}-0.026^{* *} \\
(0.012)\end{array}$ & $\begin{array}{r}-0.025^{* *} \\
(0.013)\end{array}$ & $\begin{array}{r}-0.019 \\
(0.020)\end{array}$ & $\begin{array}{r}-0.024^{* *} \\
(0.012)\end{array}$ \\
\hline Event +5 & $\begin{array}{r}-0.033^{* * *} \\
(0.013)\end{array}$ & $\begin{array}{r}-0.029^{* *} \\
(0.013)\end{array}$ & $\begin{array}{r}-0.023^{*} \\
(0.014)\end{array}$ & $\begin{array}{r}-0.027 \\
(0.023)\end{array}$ & $\begin{array}{r}-0.031^{* *} \\
(0.014)\end{array}$ \\
\hline Event +6 & $\begin{array}{r}-0.042^{* *} \\
(0.016)\end{array}$ & $\begin{array}{r}-0.044^{* *} \\
(0.017)\end{array}$ & $\begin{array}{r}-0.040^{* *} \\
(0.019)\end{array}$ & $\begin{array}{r}-0.038 \\
(0.029)\end{array}$ & $\begin{array}{r}-0.046^{* *} \\
(0.018)\end{array}$ \\
\hline Event $-3 \cdot$ care & & $\begin{array}{r}-0.003 \\
(0.007)\end{array}$ & $\begin{array}{r}0.003 \\
(0.007)\end{array}$ & $\begin{array}{r}-0.011 \\
(0.012)\end{array}$ & $\begin{array}{r}(0.018) \\
0.010 \\
(0.013)\end{array}$ \\
\hline Event $-2 \cdot$ care & & $\begin{array}{r}-0.002 \\
(0.006)\end{array}$ & $\begin{array}{r}-0.007 \\
(0.006)\end{array}$ & $\begin{array}{r}0.002 \\
(0.011)\end{array}$ & $\begin{array}{r}0.012 \\
(0.013)\end{array}$ \\
\hline Event $0 \cdot$ care & & $\begin{array}{l}-0.002 \\
(0.004)\end{array}$ & $\begin{array}{l}-0.001 \\
(0.004)\end{array}$ & $\begin{array}{l}-0.003 \\
(0.006)\end{array}$ & $\begin{array}{r}-0.002 \\
(0.012)\end{array}$ \\
\hline Event $+1 \cdot$ care & & -0.002 & -0.004 & -0.001 & -0.005 \\
\hline Event $+2 \cdot$ care & & $\begin{array}{l}(0.005) \\
-0.005\end{array}$ & $\begin{array}{l}(0.004) \\
-0.007\end{array}$ & $\begin{array}{l}(0.009) \\
-0.004\end{array}$ & $\begin{array}{l}(0.015) \\
-0.018\end{array}$ \\
\hline Event $+3 \cdot$ care & & $\begin{array}{l}(0.006) \\
-0.004 \\
(0.006)\end{array}$ & $\begin{array}{r}-0.009 \\
-0.006)\end{array}$ & 0.001 & $\begin{array}{r}(0.019) \\
0.001 \\
(0.012)\end{array}$ \\
\hline Event $+4 \cdot$ care & & $\begin{array}{r}0.006 \\
(0.007)\end{array}$ & $\begin{array}{r}-0.003 \\
(0.009)\end{array}$ & $\begin{array}{r}0.014 \\
(0.011)\end{array}$ & $\begin{array}{l}-0.011 \\
(0.018)\end{array}$ \\
\hline Event $+5 \cdot$ care & & $\begin{array}{r}-0.009 \\
(0.009)\end{array}$ & $\begin{array}{r}-0.023^{* *} \\
(0.010)\end{array}$ & $\begin{array}{r}0.006 \\
(0.015)\end{array}$ & $\begin{array}{l}-0.014 \\
(0.020)\end{array}$ \\
\hline Event $+6 \cdot$ ccare & & $\begin{array}{r}0.004 \\
(0.009)\end{array}$ & $\begin{array}{l}-0.002 \\
(0.009)\end{array}$ & $\begin{array}{r}0.010 \\
(0.015)\end{array}$ & $\begin{array}{l}-0.005 \\
(0.021)\end{array}$ \\
\hline Event -3 . subs. care & & & & & $\begin{array}{l}-0.016 \\
(0.013)\end{array}$ \\
\hline Event $-2 \cdot$ subs. care & & & & & $\begin{array}{l}-0.016 \\
(0.013)\end{array}$ \\
\hline Event $0 \cdot$ subs. care & & & & & $\begin{array}{r}-0.001 \\
(0.012)\end{array}$ \\
\hline Event +1 . subs. care & & & & & $\begin{array}{r}0.004 \\
(0.015)\end{array}$ \\
\hline Event $+2 \cdot$ subs. care & & & & & $\begin{array}{r}0.014 \\
(0.019)\end{array}$ \\
\hline Event +3 . subs. care & & & & & $\begin{array}{r}-0.007 \\
(0.012)\end{array}$ \\
\hline Event +4 . subs. care & & & & & $\begin{array}{r}0.017 \\
(0.017)\end{array}$ \\
\hline Event +5 . subs. care & & & & & $\begin{array}{r}0.006 \\
(0.020)\end{array}$ \\
\hline Event +6 . subs. care & & & & & $\begin{array}{r}0.008 \\
(0.021)\end{array}$ \\
\hline Indiv. FE & Yes & Yes & Yes & Yes & Yes \\
\hline Year FE & Yes & Yes & Yes & Yes & Yes \\
\hline Age FE & Yes & Yes & Yes & Yes & Yes \\
\hline Married $(\mathbf{t}<0)$ & Yes & Yes & Yes & Yes & Yes \\
\hline $\mathrm{N}$ indiv. & 1959 & 1959 & 1001 & 958 & 1767 \\
\hline $\mathrm{N}$ & 21437 & 21437 & 11194 & 10243 & 19359 \\
\hline
\end{tabular}

Notes: Event study estimates of male participation rates relative to the year prior to the birth of their first child. The interaction terms with childcare (care) indicate the differential effect if at the birth of the first child, there are childcare facilities in the municipality of residence. The interaction terms with subsidized childcare (subs. care) indicate the difference if at the birth of the first child, there are subsidized childcare facilities in the municipality of residence compared to if there is no childcare. Standard errors are bootstrapped (1000 replications) as the estimates of earnings changes are transformed into percentage changes after the estimation by dividing the estimates by earnings, i.e. predicted earnings when setting event time dummies to zero. Significance levels: ${ }^{*} \mathrm{p}<0.10,{ }^{* *} \mathrm{p}<0.05,{ }^{* * *} \mathrm{p}<0.01$. 
Table A.6: Earnings penalty, household level

\begin{tabular}{|c|c|c|c|c|}
\hline Perc. points change & Overall & Childcare & $\begin{array}{c}\text { Childcare \& } \\
\text { Hh earn. }>\text { p50 }\end{array}$ & $\begin{array}{c}\text { Childcare \& } \\
\text { Hh earn. } \leq \text { p50 }\end{array}$ \\
\hline & (1) & (2) & (3) & (4) \\
\hline Event -3 & $\begin{array}{r}-0.020^{* *} \\
(0.010)\end{array}$ & $\begin{array}{l}-0.022^{*} \\
(0.013)\end{array}$ & $\begin{array}{r}-0.050^{* * *} \\
(0.016)\end{array}$ & $\begin{array}{r}0.017 \\
(0.020)\end{array}$ \\
\hline Event -2 & $\begin{array}{r}-0.013^{* *} \\
(0.005)\end{array}$ & $\begin{array}{r}-0.011 \\
(0.007)\end{array}$ & $\begin{array}{r}-0.022^{* *} \\
(0.009)\end{array}$ & $\begin{array}{r}0.006 \\
(0.011)\end{array}$ \\
\hline Event 0 & $\begin{array}{r}-0.079^{* * *} \\
(0.006)\end{array}$ & $\begin{array}{r}-0.083^{* * *} \\
(0.007)\end{array}$ & $\begin{array}{r}-0.088^{* * *} \\
(0.010)\end{array}$ & $\begin{array}{r}-0.079 * * * \\
(0.011)\end{array}$ \\
\hline Event +1 & $\begin{array}{r}-0.238^{* * *} \\
(0.007)\end{array}$ & $\begin{array}{r}-0.241^{* * *} \\
(0.008)\end{array}$ & $\begin{array}{r}-0.253^{* * *} \\
(0.010)\end{array}$ & $\begin{array}{r}-0.231^{* * *} \\
(0.013)\end{array}$ \\
\hline Event +2 & $\begin{array}{r}-0.247^{* * * *} \\
(0.008)\end{array}$ & $\begin{array}{r}-0.248^{* * * *} \\
(0.008)\end{array}$ & $\begin{array}{r}-0.266^{* * *} \\
(0.011)\end{array}$ & $\begin{array}{r}-0.228^{* * *} \\
(0.015)\end{array}$ \\
\hline Event +3 & $\begin{array}{r}-0.248^{* * * *} \\
(0.009)\end{array}$ & $\begin{array}{r}-0.246^{* * *} \\
(0.010)\end{array}$ & $\begin{array}{r}-0.272^{* * *} \\
(0.013)\end{array}$ & $\begin{array}{r}-0.215^{* * *} \\
(0.019)\end{array}$ \\
\hline Event +4 & $\begin{array}{r}-0.255^{* * *} \\
(0.010)\end{array}$ & $\begin{array}{r}-0.257^{* * *} \\
(0.012)\end{array}$ & $\begin{array}{r}-0.288^{* * *} \\
(0.015)\end{array}$ & $\begin{array}{r}-0.214^{* * * *} \\
(0.022)\end{array}$ \\
\hline Event +5 & $\begin{array}{r}-0.260^{* * *} \\
(0.012)\end{array}$ & $\begin{array}{r}-0.257^{* * * *} \\
(0.013)\end{array}$ & $\begin{array}{r}-0.283^{* * *} \\
(0.016)\end{array}$ & $\begin{array}{r}-0.221^{* * *} \\
(0.023)\end{array}$ \\
\hline Event +6 & $\begin{array}{r}-0.265^{* * *} \\
(0.014)\end{array}$ & $\begin{array}{r}-0.263^{* * *} \\
(0.015)\end{array}$ & $\begin{array}{r}-0.301^{* * *} \\
(0.018)\end{array}$ & $\begin{array}{r}-0.206^{* * *} \\
(0.028)\end{array}$ \\
\hline Event $-3 \cdot$ care & & $\begin{array}{r}0.004 \\
(0.011)\end{array}$ & $\begin{array}{r}0.017 \\
(0.012)\end{array}$ & $\begin{array}{r}-0.003 \\
(0.017)\end{array}$ \\
\hline Event $-2 \cdot$ care & & $\begin{array}{r}-0.003 \\
(0.008)\end{array}$ & $\begin{array}{r}-0.001 \\
(0.010)\end{array}$ & $\begin{array}{l}-0.004 \\
(0.012)\end{array}$ \\
\hline Event $0 \cdot$ care & & 0.007 & $\begin{array}{r}0.009 \\
(0.009)\end{array}$ & 0.006 \\
\hline Event $+1 \cdot$ care & & $\begin{array}{r}(0.007) \\
0.005 \\
(0.009)\end{array}$ & $\begin{array}{r}(0.009) \\
0.000 \\
(0.010)\end{array}$ & $\begin{array}{r}(0.011) \\
0.021 \\
(0.014)\end{array}$ \\
\hline Event $+2 \cdot$ care & & $\begin{array}{r}0.002 \\
(0.009)\end{array}$ & $\begin{array}{l}-0.003 \\
(0.010)\end{array}$ & $\begin{array}{r}0.019 \\
(0.015)\end{array}$ \\
\hline Event $+3 \cdot$ care & & $\begin{array}{l}-0.004 \\
(0.010)\end{array}$ & $\begin{array}{l}-0.007 \\
(0.012)\end{array}$ & $\begin{array}{r}0.012 \\
(0.017)\end{array}$ \\
\hline Event $+4 \cdot$ care & & 0.003 & $\begin{array}{l}-0.003 \\
(0.013)\end{array}$ & 0.027 \\
\hline Event $+5 \cdot$ care & & $\begin{array}{l}(0.012) \\
-0.006 \\
(0.013)\end{array}$ & $\begin{array}{l}(0.013) \\
-0.021 \\
(0.014)\end{array}$ & $\begin{array}{r}(0.019) \\
0.030 \\
(0.020)\end{array}$ \\
\hline Event $+6 \cdot$ care & & $\begin{array}{l}(0.013) \\
-0.004 \\
(0.015)\end{array}$ & $\begin{array}{l}(0.014) \\
-0.003 \\
(0.017)\end{array}$ & $\begin{array}{r}(0.0202 \\
0.002 \\
(0.023)\end{array}$ \\
\hline Indiv. FE & Yes & Yes & Yes & Yes \\
\hline $\begin{array}{l}\text { Year FE } \\
\text { Age FE }\end{array}$ & $\begin{array}{l}\text { Yes } \\
\text { Yes }\end{array}$ & $\begin{array}{l}\text { Yes } \\
\text { Yes }\end{array}$ & $\begin{array}{l}\text { Yes } \\
\text { Yes }\end{array}$ & $\begin{array}{l}\text { Yes } \\
\text { Yes }\end{array}$ \\
\hline Married $(\mathrm{t}<0)$ & Yes & Yes & Yes & Yes \\
\hline $\begin{array}{l}\mathrm{N} \text { indiv. } \\
\mathrm{N}\end{array}$ & $\begin{array}{r}1959 \\
21437\end{array}$ & $\begin{array}{r}1959 \\
21437\end{array}$ & $\begin{array}{r}1001 \\
11194\end{array}$ & $\begin{array}{r}958 \\
10243\end{array}$ \\
\hline
\end{tabular}

Notes: Event study estimates of both parents' combined earnings relative to the year prior to the birth of their first child in columns (1)-(4) and of the female earnings share in column (5). The interaction terms with childcare (care) indicate the differential effect if at the birth of the first child, there are childcare facilities in the municipality of residence. Standard errors are bootstrapped (1000 replications) as the estimates of earnings changes are transformed into percentage changes after the estimation by dividing the estimates by earnings, i.e., predicted earnings when setting event time dummies to zero. In specification (5), the dependent variable is the female earnings share and estimates do not need to be transformed. Standard errors here are clustered at the individual level. There are less observations in specification (5) as the female earnings share cannot be calculated if both partners have an income of 0 . Significance levels: ${ }^{*} \mathrm{p}<0.10,{ }^{* *} \mathrm{p}<0.05,{ }^{* * *} \mathrm{p}<0.01$. 
Table A.7: Female earnings share

\begin{tabular}{|c|c|c|c|}
\hline & $\begin{array}{l}\text { Overall } \\
(1)\end{array}$ & $\begin{array}{c}\text { Hh inc. }>\text { p50 } \\
\text { (2) }\end{array}$ & $\begin{array}{c}\text { Hh inc. } \leq \mathrm{p} 50 \\
(3)\end{array}$ \\
\hline \multirow{2}{*}{ Event -3} & 0.555 & 0.857 & 0.491 \\
\hline & $(0.735)$ & $(0.825)$ & $(1.228)$ \\
\hline \multirow{2}{*}{ Event -2} & 0.347 & -0.127 & 1.061 \\
\hline & $(0.463)$ & $(0.482)$ & $(0.788)$ \\
\hline \multirow[t]{2}{*}{ Event 0} & $-10.398^{* * *}$ & $-7.947^{* * *}$ & $-13.193^{* * *}$ \\
\hline & $(0.602)$ & (0.739) & (0.947) \\
\hline \multirow[t]{2}{*}{ Event +1} & $-25.617 * * *$ & $-23.336^{* * *}$ & $-28.389^{* * *}$ \\
\hline & $(0.800)$ & $(0.958)$ & (1.268) \\
\hline \multirow[t]{2}{*}{ Event +2} & $-26.404^{* * *}$ & $-25.078^{* * *}$ & $-28.356^{* * *}$ \\
\hline & $(0.907)$ & $(1.081)$ & (1.458) \\
\hline \multirow[t]{2}{*}{ Event +3} & $-28.063^{* * *}$ & $-26.445^{* * *}$ & $-30.516^{* * *}$ \\
\hline & (1.034) & $(1.230)$ & (1.661) \\
\hline \multirow[t]{2}{*}{ Event +4} & $-28.468^{* * *}$ & $-26.667^{* * *}$ & $-31.129^{* * *}$ \\
\hline & $(1.157)$ & (1.368) & (1.877) \\
\hline \multirow{2}{*}{ Event +5} & $-28.285^{* * *}$ & $-26.647 * * *$ & $-30.711^{* * *}$ \\
\hline & (1.298) & $(1.516)$ & (2.131) \\
\hline \multirow{2}{*}{ Event +6} & $-28.133^{* * *}$ & $-26.440^{* * *}$ & $-30.615^{* * *}$ \\
\hline & $(1.543)$ & (1.776) & $(2.570)$ \\
\hline \multirow[t]{2}{*}{ Event $-3 \cdot$ care } & 0.041 & -0.465 & 0.620 \\
\hline & $(0.710)$ & $(0.789)$ & (1.208) \\
\hline \multirow[t]{2}{*}{ Event $-2 \cdot$ care } & -0.573 & 0.099 & -1.279 \\
\hline & $(0.520)$ & $(0.513)$ & $(0.913)$ \\
\hline \multirow[t]{2}{*}{ Event $0 \cdot$ care } & $1.338^{* * *}$ & $1.217^{* *}$ & 1.311 \\
\hline & $(0.504)$ & $(0.564)$ & $(0.836)$ \\
\hline \multirow[t]{2}{*}{ Event $+1 \cdot$ care } & $2.403^{* * *}$ & $1.444^{*}$ & $3.280^{* * *}$ \\
\hline & $(0.728)$ & $(0.850)$ & (1.179) \\
\hline \multirow{2}{*}{ Event $+2 \cdot$ care } & $2.423^{* * *}$ & $1.565^{*}$ & $3.345^{* * *}$ \\
\hline & $(0.775)$ & $(0.898)$ & $(1.263)$ \\
\hline \multirow[t]{2}{*}{ Event $+3 \cdot$ care } & $2.427^{* * *}$ & 1.053 & $4.082^{* * *}$ \\
\hline & $(0.814)$ & $(0.960)$ & $(1.310)$ \\
\hline \multirow[t]{2}{*}{ Event $+4 \cdot$ care } & $2.746^{* * *}$ & 1.185 & $4.551^{* * *}$ \\
\hline & $(0.864)$ & $(1.030)$ & $(1.400)$ \\
\hline \multirow[t]{2}{*}{ Event $+5 \cdot$ care } & $2.466^{* * *}$ & 1.042 & $3.989^{* * *}$ \\
\hline & $(0.936)$ & (1.110) & $(1.524)$ \\
\hline \multirow[t]{2}{*}{ Event $+6 \cdot$ care } & $2.706^{* * *}$ & 0.615 & $5.089^{* * *}$ \\
\hline & (1.031) & (1.196) & (1.708) \\
\hline \multirow[t]{2}{*}{ Constant } & $38.462^{* * *}$ & $45.624^{* * *}$ & $37.699 * * *$ \\
\hline & (2.085) & $(4.440)$ & (2.792) \\
\hline Indiv. FE & Yes & Yes & Yes \\
\hline Year FE & Yes & Yes & Yes \\
\hline Age FE & Yes & Yes & Yes \\
\hline Married $(\mathrm{t}<0)$ & Yes & Yes & Yes \\
\hline $\mathrm{N}$ indiv. & 1959 & 1001 & 958 \\
\hline $\mathrm{N}$ & 21294 & 11149 & 10145 \\
\hline
\end{tabular}

Notes: Event study estimates of the earnings share contributed by the woman to total household earnings relative to the year prior to the birth of their first child. The interaction terms with childcare (care) indicate the differential effect if at the birth of the first child, there are childcare facilities in the municipality of residence. Constant refers to the average female income share after controlling for year FE, age FE, married, and all the event indicators. Standard errors are clustered at the individual level. Significance levels: ${ }^{*} \mathrm{p}<0.10,{ }^{* *} \mathrm{p}<0.05,{ }^{* * *} \mathrm{p}<0.01$. 
Table A.8: Take-up: Effect on childcare deductions

\begin{tabular}{|c|c|c|}
\hline & $\begin{array}{c}\text { Total amount } \\
\text { (1) }\end{array}$ & $\begin{array}{c}\mathrm{P} \text { (deduction) } \\
\text { (2) }\end{array}$ \\
\hline Event 0 & $\begin{array}{r}307.583^{* * *} \\
(57.387)\end{array}$ & $\begin{array}{r}0.166^{* * *} \\
(0.018)\end{array}$ \\
\hline Event +1 & $\begin{array}{r}645.668^{* * *} \\
(82.153)\end{array}$ & $\begin{array}{r}0.295^{* * *} \\
(0.025)\end{array}$ \\
\hline Event +2 & $\begin{array}{r}909.776^{* * *} \\
(108.323)\end{array}$ & $\begin{array}{r}0.353^{* * *} \\
(0.030)\end{array}$ \\
\hline Event +3 & $\begin{array}{r}1231.285^{* * *} \\
(138.909)\end{array}$ & $\begin{array}{r}0.427^{* * *} \\
(0.037)\end{array}$ \\
\hline Event +4 & $\begin{array}{r}1503.369^{* * *} \\
(167.279)\end{array}$ & $\begin{array}{r}0.490^{* * *} \\
(0.044)\end{array}$ \\
\hline Event +5 & $\begin{array}{r}1609.405^{* * *} \\
(195.250)\end{array}$ & $\begin{array}{r}0.521^{* * *} \\
(0.050)\end{array}$ \\
\hline Event +6 & $\begin{array}{r}1460.833^{* * *} \\
(232.263)\end{array}$ & $\begin{array}{r}0.471^{* * *} \\
(0.061)\end{array}$ \\
\hline Event $0 \cdot$ care & $\begin{array}{r}0.739 \\
(27.827)\end{array}$ & $\begin{array}{r}-0.017 \\
(0.016)\end{array}$ \\
\hline Event $+1 \cdot$ care & $\begin{array}{r}178.320^{* * *} \\
(46.934)\end{array}$ & $\begin{array}{r}0.032 \\
(0.020)\end{array}$ \\
\hline Event $+2 \cdot$ care & $\begin{array}{r}200.419^{* * *} \\
(59.161)\end{array}$ & $\begin{array}{r}0.042^{* *} \\
(0.021)\end{array}$ \\
\hline Event $+3 \cdot$ care & $\begin{array}{r}291.782^{* * *} \\
(82.931)\end{array}$ & $\begin{array}{r}0.056^{* *} \\
(0.023)\end{array}$ \\
\hline Event $+4 \cdot$ care & $\begin{array}{r}248.515^{* *} \\
(100.277)\end{array}$ & $\begin{array}{r}0.021 \\
(0.025)\end{array}$ \\
\hline Event $+5 \cdot$ care & $\begin{array}{c}228.496^{* *} \\
(110.802)\end{array}$ & $\begin{array}{r}0.006 \\
(0.026)\end{array}$ \\
\hline Event $+6 \cdot$ care & $\begin{array}{r}412.706^{* * *} \\
(111.475)\end{array}$ & $\begin{array}{r}0.094^{* * *} \\
(0.026)\end{array}$ \\
\hline Indiv. FE & Yes & Yes \\
\hline Year FE & Yes & Yes \\
\hline Age FE & Yes & Yes \\
\hline Married $(\mathrm{t}<0)$ & Yes & Yes \\
\hline $\mathrm{N}$ indiv. & 1959 & 1959 \\
\hline $\mathrm{N}$ & 14760 & 14760 \\
\hline
\end{tabular}

Notes: Event study estimates of filings for child deductions, in specification (1) using total amount deduced in CHF as dependent variable and in specification (2) using an indicator set to one if a positive amount is claimed as dependent variable. care, takes a value of one for treated municipalities after the introduction of childcare and zero otherwise. The event time dummies capture changes relative to the year before the opening of a childcare facility $t=-1$. Robust standard errors in parentheses. Significance levels: ${ }^{*} \mathrm{p}<0.10,{ }^{* *} \mathrm{p}<0.05,{ }^{* * *} \mathrm{p}<0.01$. 
Figure A.1: Probability of childbirth relative to the year before the opening of childcare

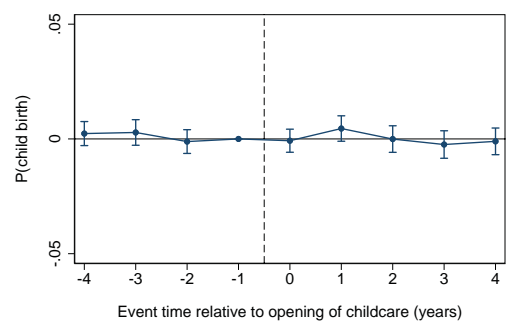

Note: Probability of childbirth relative to the year before the opening of a childcare facility. The specification controls for year effects and individual fixed effects. Event time $t=-4$ includes years $\leq-4$ before the opening of a childcare facility. Event time $t=4$ includes years $\geq 4$ after the opening of a childcare facility. Standard errors are clustered at the individual level. The corresponding estimates can be found in column (2) of Table A.9 in Appendix A. 
Table A.9: Effect of childcare on fertility

\begin{tabular}{|c|c|c|}
\hline & $\begin{array}{l}\mathrm{DiD} \\
(1)\end{array}$ & $\begin{array}{c}\text { Event study } \\
\text { (2) }\end{array}$ \\
\hline Care & $\begin{array}{r}0.000 \\
(0.001)\end{array}$ & \\
\hline Mun. with care & $\begin{array}{r}0.001 \\
(0.001)\end{array}$ & \\
\hline Event -4 & & $\begin{array}{r}0.002 \\
(0.003)\end{array}$ \\
\hline Event -3 & & $\begin{array}{r}0.003 \\
(0.003)\end{array}$ \\
\hline Event -2 & & $\begin{array}{r}-0.001 \\
(0.003)\end{array}$ \\
\hline Event 0 & & $\begin{array}{r}-0.001 \\
(0.003)\end{array}$ \\
\hline Event +1 & & $\begin{array}{r}0.005 \\
(0.003)\end{array}$ \\
\hline Event +2 & & $\begin{array}{r}-0.000 \\
(0.003)\end{array}$ \\
\hline Event +3 & & $\begin{array}{r}-0.002 \\
(0.003)\end{array}$ \\
\hline Event +4 & & $\begin{array}{r}-0.001 \\
(0.003) \\
\end{array}$ \\
\hline Year FE & Yes & Yes \\
\hline Individual $\mathrm{FE}$ & No & Yes \\
\hline $\mathrm{N}$ indiv. & & 30,480 \\
\hline N & 494,601 & 190,453 \\
\hline $\mathrm{N}$ cluster & 366 & \\
\hline
\end{tabular}

Notes: Event study estimates of fertility rates, once as a DiD around the opening of a childcare facility and once as an event study around the opening of a childcare facility. In the DiD specification, municipalities opening a childcare facility between 2001 and 2015 are defined as the treatment group (mun. with care). Municipalities that have not opened a childcare facility by the end of 2015 are used as the control group. The indicator care takes value one for treated municipalities after the introduction of childcare and zero otherwise. Specification (2) only includes individuals in municipalities that did introduce childcare. The event time indicators capture changes relative to the year before the opening of a childcare facility $t=-1$. Standard errors are clustered at the municipality level for the DiD and at the individual level for the event study. Significance levels: ${ }^{*} \mathrm{p}<0.10,{ }^{* *} \mathrm{p}<0.05,{ }^{* * *} \mathrm{p}<0.01$. 
Table A.10: Robustness tests, women

\begin{tabular}{|c|c|c|c|c|}
\hline & Stayer & $\begin{array}{c}\text { Stayer } \\
\text { subsid. care }\end{array}$ & Selection & $\begin{array}{l}+-3 \text { yrs } \\
\text { around opening }\end{array}$ \\
\hline & $(1)$ & $(2)$ & (3) & (4) \\
\hline Event -3 & $\begin{array}{r}0.008 \\
(0.020)\end{array}$ & $\begin{array}{r}0.009 \\
(0.021)\end{array}$ & $\begin{array}{r}-0.019^{* *} \\
(0.009)\end{array}$ & $\begin{array}{r}-0.026 \\
(0.026)\end{array}$ \\
\hline \multirow[t]{2}{*}{ Event -2} & -0.006 & -0.008 & $-0.009^{*}$ & -0.005 \\
\hline & $(0.010)$ & $(0.011)$ & $(0.005)$ & $(0.016)$ \\
\hline \multirow[t]{2}{*}{ Event +1} & $-0.647^{* * *}$ & $-0.656 * * *$ & $-0.644^{* * *}$ & $-0.643^{* * *}$ \\
\hline & $(0.013)$ & $(0.013)$ & $(0.006)$ & $(0.015)$ \\
\hline \multirow[t]{2}{*}{ Event +2} & $-0.662^{* * *}$ & $-0.671^{* * *}$ & $-0.667^{* * *}$ & $-0.669^{* * *}$ \\
\hline & $(0.013)$ & $(0.014)$ & $(0.006)$ & $(0.016)$ \\
\hline \multirow[t]{2}{*}{ Event +3} & $-0.689 * * *$ & $-0.697^{* * *}$ & $-0.697^{* * *}$ & $-0.688^{* * *}$ \\
\hline & $(0.014)$ & $(0.014)$ & $(0.006)$ & $(0.018)$ \\
\hline \multirow{2}{*}{ Event +4} & $-0.700 * * *$ & $-0.705^{* * *}$ & $-0.708^{* * *}$ & $-0.724^{* * *}$ \\
\hline & $(0.016)$ & $(0.016)$ & $(0.007)$ & $(0.019)$ \\
\hline \multirow[t]{2}{*}{ Event +5} & $-0.704 * * *$ & $-0.709 * * *$ & $-0.721^{* * *}$ & $-0.717^{* * *}$ \\
\hline & $(0.017)$ & $(0.017)$ & $(0.008)$ & $(0.023)$ \\
\hline \multirow[t]{2}{*}{ Event +6} & $-0.709 * * *$ & $-0.713^{* * *}$ & $-0.734^{* * *}$ & $-0.743^{* * *}$ \\
\hline & $(0.019)$ & $(0.019)$ & $(0.009)$ & $(0.028)$ \\
\hline \multirow{2}{*}{ Event $-3 \cdot$ care } & -0.019 & -0.010 & -0.016 & $0.040^{*}$ \\
\hline & $(0.018)$ & $(0.035)$ & $(0.011)$ & $(0.023)$ \\
\hline Event $-2 \cdot$ care & $-0.019^{*}$ & -0.005 & -0.005 & -0.006 \\
\hline \multirow{2}{*}{ Event $0 \cdot$ care } & $\begin{array}{r}(0.011) \\
0.033^{* * *}\end{array}$ & $\begin{array}{r}(0.017) \\
0.064^{* * *}\end{array}$ & $\begin{array}{r}(0.008) \\
-0.002\end{array}$ & $\begin{array}{l}(0.018) \\
0.044^{* *}\end{array}$ \\
\hline & $(0.013)$ & $(0.024)$ & $(0.009)$ & $(0.018)$ \\
\hline \multirow[t]{2}{*}{ Event $+1 \cdot$ care } & $0.040^{* *}$ & 0.003 & -0.006 & $0.046^{*}$ \\
\hline & $(0.017)$ & $(0.037)$ & $(0.011)$ & $(0.024)$ \\
\hline \multirow[t]{2}{*}{ Event $+2 \cdot$ care } & $0.037^{* *}$ & 0.003 & 0.007 & 0.039 \\
\hline & $(0.018)$ & $(0.037)$ & $(0.012)$ & $(0.024)$ \\
\hline \multirow[t]{2}{*}{ Event $+3 \cdot$ care } & $0.038^{* *}$ & -0.006 & 0.001 & $0.044^{*}$ \\
\hline & $(0.019)$ & $(0.039)$ & $(0.013)$ & $(0.025)$ \\
\hline \multirow[t]{2}{*}{ Event $+4 \cdot$ care } & $0.040^{*}$ & 0.002 & 0.010 & $0.066^{* *}$ \\
\hline & $(0.020)$ & $(0.043)$ & $(0.015)$ & $(0.026)$ \\
\hline \multirow[t]{2}{*}{ Event $+5 \cdot$ care } & $0.042^{*}$ & 0.009 & 0.011 & 0.046 \\
\hline & $(0.022)$ & $(0.048)$ & $(0.016)$ & $(0.029)$ \\
\hline \multirow[t]{2}{*}{ Event $+6 \cdot$ care } & $0.054^{* *}$ & 0.013 & 0.006 & $0.074^{* *}$ \\
\hline & $(0.026)$ & $(0.045)$ & $(0.019)$ & $(0.035)$ \\
\hline Event $-3 \cdot$ subs. care & & $\begin{array}{r}-0.010 \\
(0.020)\end{array}$ & & \\
\hline Event $-2 \cdot$ subs. care & & -0.014 & & \\
\hline & & $(0.013)$ & & \\
\hline Event $0 \cdot$ subs. care & & $\begin{array}{r}0.036^{* *} \\
(0.014)\end{array}$ & & \\
\hline Event +1 . subs. care & & $0.057^{* * *}$ & & \\
\hline & & $(0.019)$ & & \\
\hline Event $+2 \cdot$ subs. care & & $0.053^{* * *}$ & & \\
\hline Event +3 . subs. care & & $\begin{array}{l}(0.020) \\
0.050^{* *}\end{array}$ & & \\
\hline & & $(0.021)$ & & \\
\hline Event +4 . subs. care & & $0.053^{* *}$ & & \\
\hline Event +5 . subs care & & $\begin{array}{l}(0.022) \\
0.055^{* *}\end{array}$ & & \\
\hline Event + J. subs. care & & $(0.024)$ & & \\
\hline Event +6 . subs. care & & $0.070^{* *}$ & & \\
\hline & & $(0.029)$ & & \\
\hline Indiv. FE & Yes & Yes & Yes & Yes \\
\hline Year FE & Yes & Yes & Yes & Yes \\
\hline Age FE & Yes & Yes & Yes & Yes \\
\hline Married $(\mathrm{t}<0)$ & Yes & Yes & Yes & Yes \\
\hline $\mathrm{N}$ indiv. & 1460 & 1336 & 4310 & 760 \\
\hline $\mathrm{N}$ & 15978 & 14648 & 41595 & 8102 \\
\hline
\end{tabular}

Notes: Event study estimates of female earnings relative to the year prior to the birth of their first child for the robustness tests. The interaction terms with childcare (care) indicate the differential effect if at the birth of the first child, there are childcare facilities in the municipality of residence. The interaction terms with subsidized childcare (subs. care) indicate the difference if at the birth of the first child, there are subsidized childcare facilities in the municipality of residence compared to if there is no childcare. Standard errors are bootstrapped (1000 replications). Significance levels: $* \mathrm{p}<0.10,{ }^{* *} \mathrm{p}<0.05$, $* * * \mathrm{p}<0.01$. 
Table A.11: Robustness tests, men

\begin{tabular}{|c|c|c|c|c|}
\hline & Stayer & $\begin{array}{c}\text { Stayer } \\
\text { subsid. care }\end{array}$ & Selection & $\begin{array}{l}+-3 \text { yrs } \\
\text { around opening }\end{array}$ \\
\hline & (1) & $(2)$ & (3) & (4) \\
\hline Event -3 & $\begin{array}{r}-0.020 \\
(0.019)\end{array}$ & $\begin{array}{r}-0.017 \\
(0.020)\end{array}$ & $\begin{array}{r}-0.009 \\
(0.010)\end{array}$ & $\begin{array}{l}-0.041 * \\
(0.024)\end{array}$ \\
\hline Event -2 & $\begin{array}{l}-0.011 \\
(0.010)\end{array}$ & $\begin{array}{l}-0.009 \\
(0.010)\end{array}$ & $\begin{array}{r}-0.010^{* *} \\
(0.005)\end{array}$ & $\begin{array}{r}-0.016 \\
(0.016)\end{array}$ \\
\hline Event 0 & $\begin{array}{r}0.041^{* * *} \\
(0.013)\end{array}$ & $\begin{array}{r}0.040^{* * *} \\
(0.013)\end{array}$ & $\begin{array}{r}0.037^{* * *} \\
(0.008)\end{array}$ & $\begin{array}{r}0.055^{* * *} \\
(0.017)\end{array}$ \\
\hline Event +1 & $\begin{array}{r}0.061^{* * *} \\
(0.018)\end{array}$ & $\begin{array}{r}0.061^{* * *} \\
(0.018)\end{array}$ & $\begin{array}{r}0.042^{* * *} \\
(0.009)\end{array}$ & $\begin{array}{r}0.088^{* * *} \\
(0.022)\end{array}$ \\
\hline Event +2 & $\begin{array}{r}0.062^{* * *} \\
(0.020)\end{array}$ & $\begin{array}{r}0.062^{* * *} * \\
(0.021)\end{array}$ & $\begin{array}{r}0.046^{* * *} \\
(0.011)\end{array}$ & $\begin{array}{r}0.083^{* * *} * \\
(0.024)\end{array}$ \\
\hline Event +3 & $\begin{array}{r}0.082^{* * *} \\
(0.023)\end{array}$ & $\begin{array}{r}0.083^{* * *} \\
(0.025)\end{array}$ & $\begin{array}{r}0.052^{* * *} \\
(0.013)\end{array}$ & $\begin{array}{r}0.095^{* * *} \\
(0.031)\end{array}$ \\
\hline Event +4 & $\begin{array}{r}0.075^{* * *} \\
(0.026)\end{array}$ & $\begin{array}{r}0.077^{* * *} \\
(0.027)\end{array}$ & $\begin{array}{r}0.057^{* * *} \\
(0.016)\end{array}$ & $\begin{array}{r}0.083^{* *} \\
(0.037)\end{array}$ \\
\hline Event +5 & $\begin{array}{r}0.085^{* * *} \\
(0.028)\end{array}$ & $\begin{array}{r}0.085^{* * *} \\
(0.029)\end{array}$ & $\begin{array}{r}0.069^{* * *} \\
(0.019)\end{array}$ & $\begin{array}{r}0.131^{* * *} \\
(0.043)\end{array}$ \\
\hline Event +6 & $\begin{array}{r}0.076^{* *} \\
(0.032)\end{array}$ & $\begin{array}{r}0.074^{* *} \\
(0.033)\end{array}$ & $\begin{array}{r}0.079^{* * *} \\
(0.024)\end{array}$ & $\begin{array}{r}0.111^{* *} \\
(0.052)\end{array}$ \\
\hline Event $-3 \cdot$ care & $\begin{array}{l}-0.003 \\
(0.016)\end{array}$ & $\begin{array}{r}0.020 \\
(0.028)\end{array}$ & $\begin{array}{r}-0.031^{* * *} \\
(0.011)\end{array}$ & $\begin{array}{r}0.004 \\
(0.022)\end{array}$ \\
\hline Event $-2 \cdot$ care & $\begin{array}{r}-0.006 \\
(0.010)\end{array}$ & $\begin{array}{r}0.015 \\
(0.015)\end{array}$ & $\begin{array}{r}-0.011 \\
(0.008)\end{array}$ & $\begin{array}{r}-0.007 \\
(0.016)\end{array}$ \\
\hline Event $0 \cdot$ care & $\begin{array}{r}-0.001 \\
(0.008)\end{array}$ & $\begin{array}{r}-0.011 \\
(0.019)\end{array}$ & $\begin{array}{r}0.007 \\
(0.008)\end{array}$ & $\begin{array}{r}-0.011 \\
(0.013)\end{array}$ \\
\hline Event $+1 \cdot$ care & $\begin{array}{r}-0.014 \\
(0.013)\end{array}$ & $\begin{array}{r}-0.023 \\
(0.025)\end{array}$ & $\begin{array}{r}0.022^{* *} \\
(0.009)\end{array}$ & $\begin{array}{r}-0.028^{*} \\
(0.016)\end{array}$ \\
\hline Event $+2 \cdot$ care & $\begin{array}{r}-0.017 \\
(0.014)\end{array}$ & $\begin{array}{r}-0.020 \\
(0.030)\end{array}$ & $\begin{array}{r}0.026^{* *} \\
(0.012)\end{array}$ & $\begin{array}{r}-0.032^{* *} \\
(0.016)\end{array}$ \\
\hline Event $+3 \cdot$ care & $\begin{array}{l}-0.019 \\
(0.016)\end{array}$ & $\begin{array}{r}-0.024 \\
(0.025)\end{array}$ & $\begin{array}{r}0.041^{* * *} \\
(0.015)\end{array}$ & $\begin{array}{l}-0.034^{*} \\
(0.020)\end{array}$ \\
\hline Event $+4 \cdot$ care & $\begin{array}{l}-0.008 \\
(0.019)\end{array}$ & $\begin{array}{r}-0.010 \\
(0.029)\end{array}$ & $\begin{array}{r}0.039^{* *} \\
(0.016)\end{array}$ & $\begin{array}{r}-0.018 \\
(0.024)\end{array}$ \\
\hline Event $+5 \cdot$ care & $\begin{array}{r}-0.030 \\
(0.021)\end{array}$ & $\begin{array}{r}-0.033 \\
(0.034)\end{array}$ & $\begin{array}{r}0.028 \\
(0.021)\end{array}$ & $\begin{array}{r}-0.064^{* *} \\
(0.029)\end{array}$ \\
\hline Event $+6 \cdot$ care & $\begin{array}{r}-0.030 \\
(0.025)\end{array}$ & $\begin{array}{r}-0.072^{*} \\
(0.039)\end{array}$ & $\begin{array}{r}0.017 \\
(0.025)\end{array}$ & $\begin{array}{l}-0.033 \\
(0.035)\end{array}$ \\
\hline Event $-3 \cdot$ subs. care & & $\begin{array}{r}-0.010 \\
(0.017)\end{array}$ & & \\
\hline Event $-2 \cdot$ subs. care & & $\begin{array}{r}-0.012 \\
(0.012)\end{array}$ & & \\
\hline Event $0 \cdot$ subs. care & & $\begin{array}{r}0.002 \\
(0.009)\end{array}$ & & \\
\hline Event +1 . subs. care & & $\begin{array}{r}-0.016 \\
(0.013)\end{array}$ & & \\
\hline Event $+2 \cdot$ subs. care & & $\begin{array}{r}-0.021 \\
(0.015)\end{array}$ & & \\
\hline Event +3 . subs. care & & $\begin{array}{r}(0.015) \\
-0.022 \\
(0.018)\end{array}$ & & \\
\hline Event +4 . subs. care & & $\begin{array}{r}-0.015 \\
(0.020)\end{array}$ & & \\
\hline Event $+5 \cdot$ subs. care & & $\begin{array}{r}-0.036 \\
(0.022)\end{array}$ & & \\
\hline Event +6 . subs. care & & $\begin{array}{r}-0.022 \\
(0.027)\end{array}$ & & \\
\hline Indiv. FE & Yes & Yes & Yes & Yes \\
\hline Year FE & Yes & Yes & Yes & Yes \\
\hline Age FE & Yes & Yes & Yes & Yes \\
\hline Married $(\mathrm{t}<0)$ & Yes & Yes & Yes & Yes \\
\hline $\mathrm{N}$ indiv. & 1460 & 1336 & 4310 & 760 \\
\hline $\mathrm{N}$ & 15978 & 14648 & 41595 & 8102 \\
\hline
\end{tabular}

Notes: Event study estimates of male earnings relative to the year prior to the birth of their first child for the robustness tests. The interaction terms with childcare (care) indicate the differential effect if at the birth of the first child, there are childcare facilities in the municipality of residence. The interaction terms with subsidized childcare (subs. care) indicate the difference if at the birth of the first child, there are subsidized childcare facilities in the municipality of residence compared to if there is no childcare. Standard errors are bootstrapped (1000 replications). Significance levels: $* \mathrm{p}<0.10,{ }^{* *} \mathrm{p}<0.05$, $* * * \mathrm{p}<0.01$. 
Figure A.2: Child penalty in municipalities in main sample compared to municipalities which do not have a childcare facility by the end of 2015

(a) Effect of parenthood, women

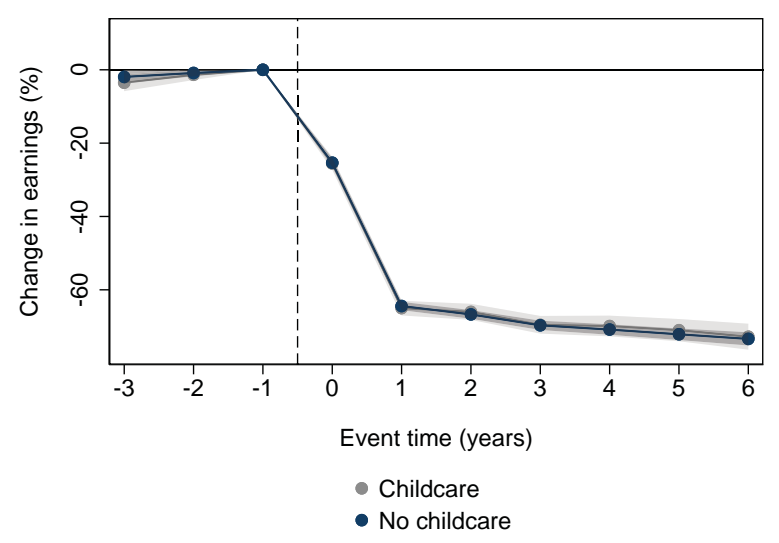

(b) Differential in child penalty, women

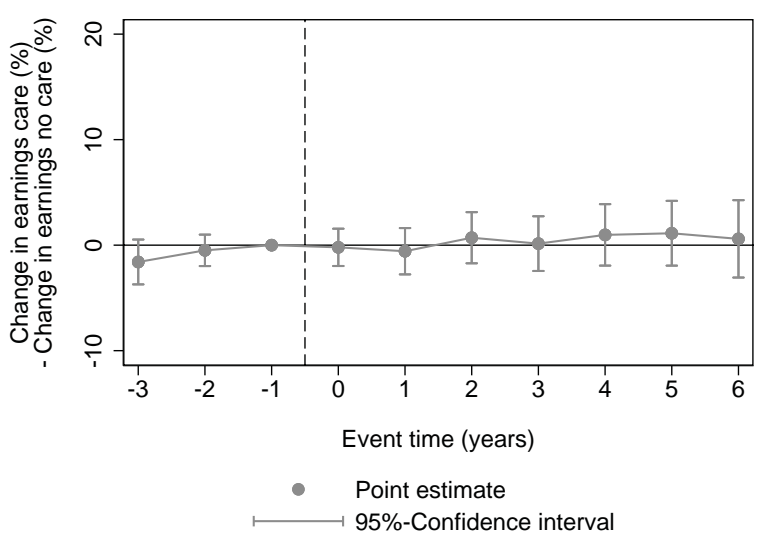

Note: Panel (a) visualizes the percentage effect of parenthood on female earnings relative to the year prior to the birth of the first child $(t=-1)$ in municipalities that introduce childcare at some point (Childcare), in years before they do, and in municipalities that do not have childcare by the end of 2015 (No childcare). Confidence bounds are calculated applying a non-parametric bootstrap and are displayed at the 5 percent level. Panel (b) plots the estimated differences in the child penalty between the two groups of municipalities. 


\section{Histograms for placebo test}

Figure A.3: Histograms of placebo test, women

$t=-3$

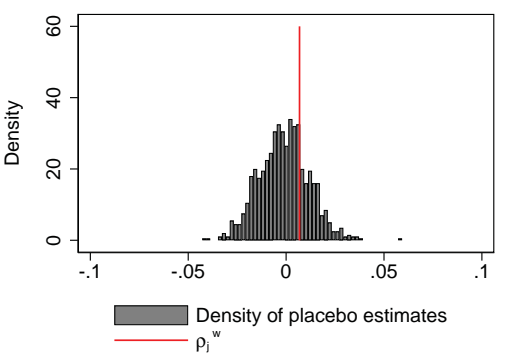

$t=1$

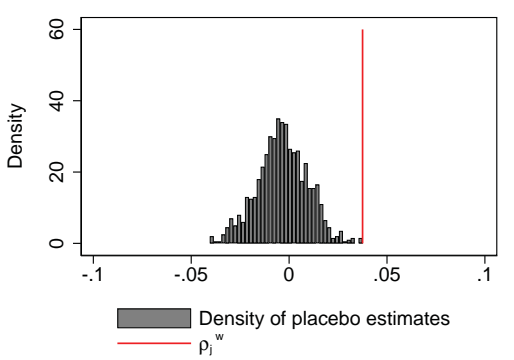

$t=4$

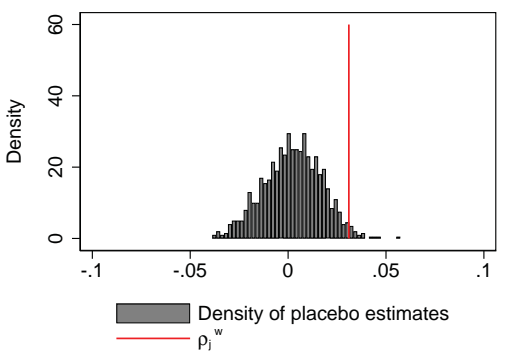

$t=-2$

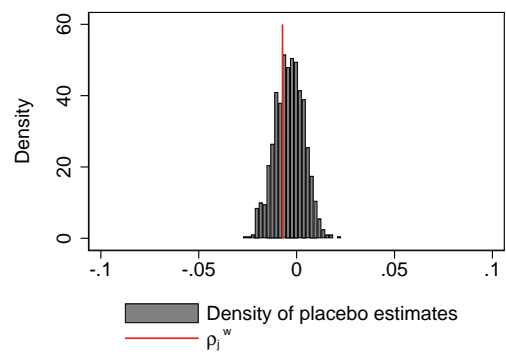

$t=2$

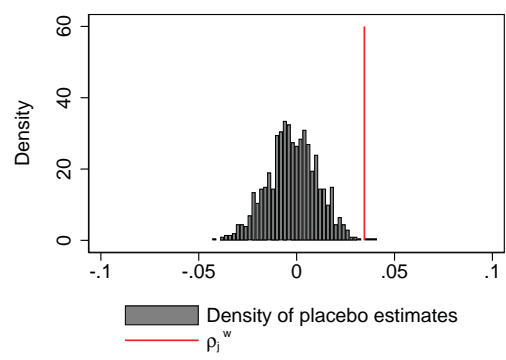

$t=5$

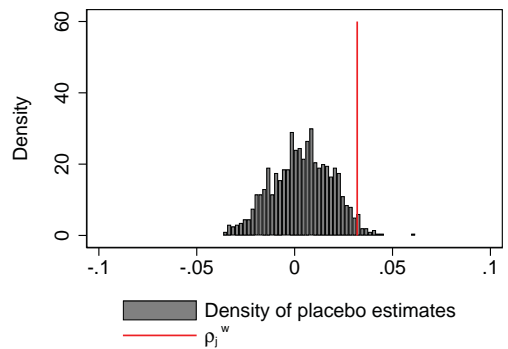

$t=0$

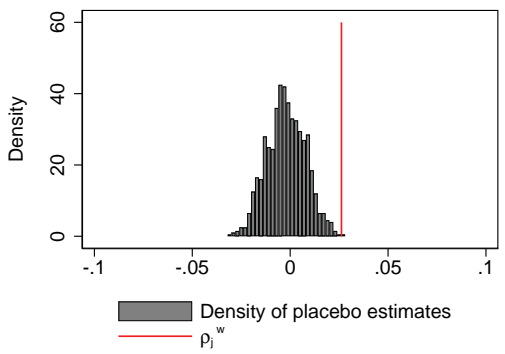

$t=3$

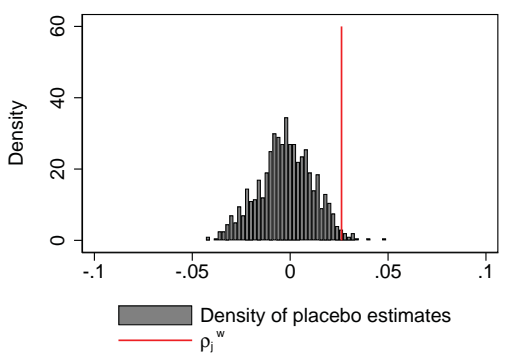

$t=6$

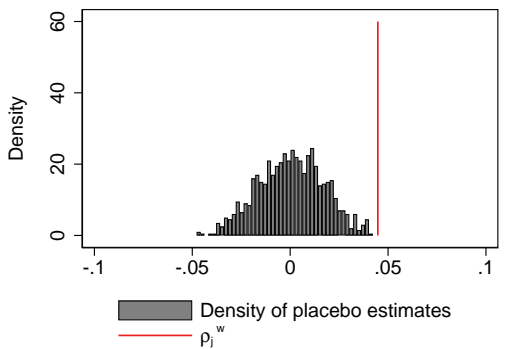

Note: Results of the placebo test where opening dates of childcare are randomly assigned to municipalities that do not have childcare for women. Based on these placebo opening dates, we replicate the analysis of the effect of childcare on earnings based on this sample. The densities are the result of 1000 random assignments of opening dates. The red lines show the actual estimates of the effect of childcare. 
Figure A.4: Histograms of placebo test, men

$t=-3$

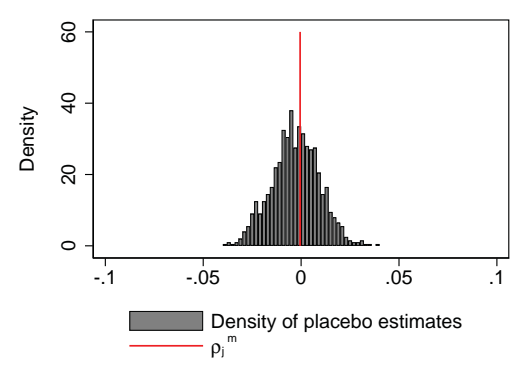

$t=1$

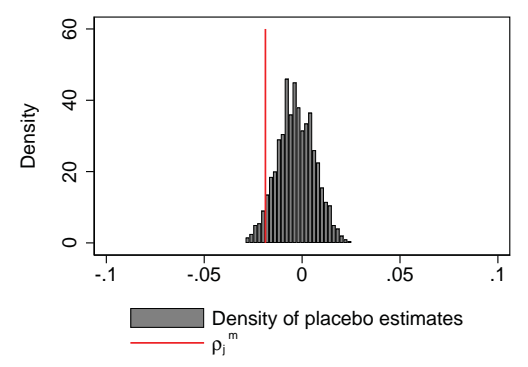

$t=4$

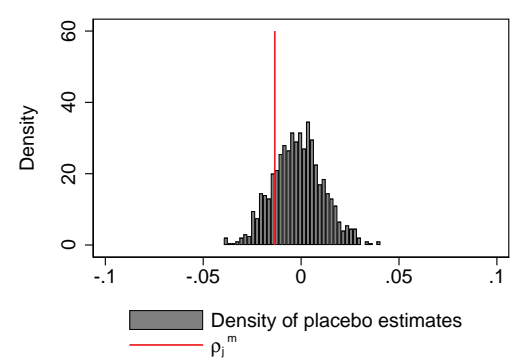

$t=-2$

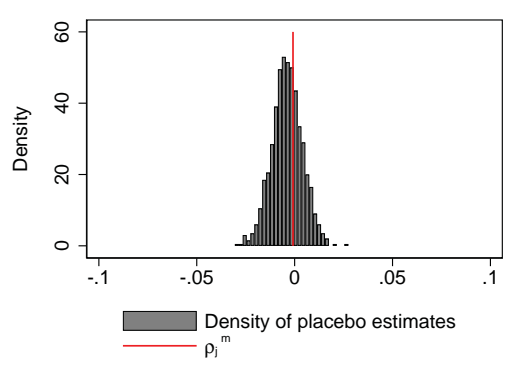

$t=2$

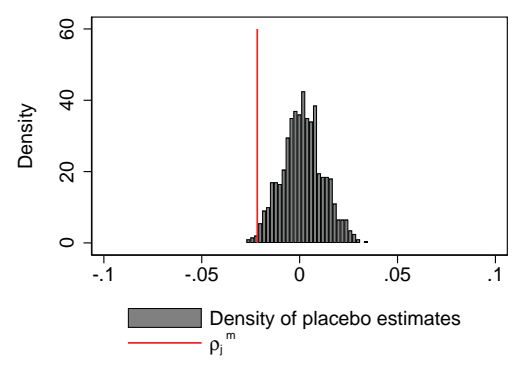

$t=5$

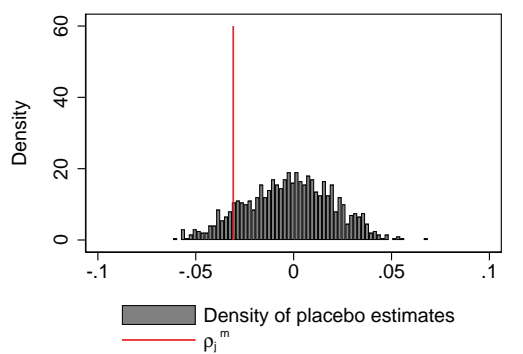

$t=0$

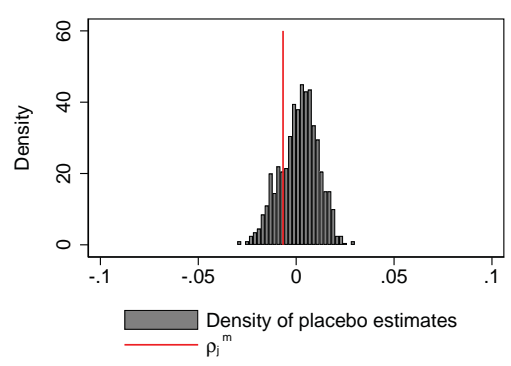

$t=3$

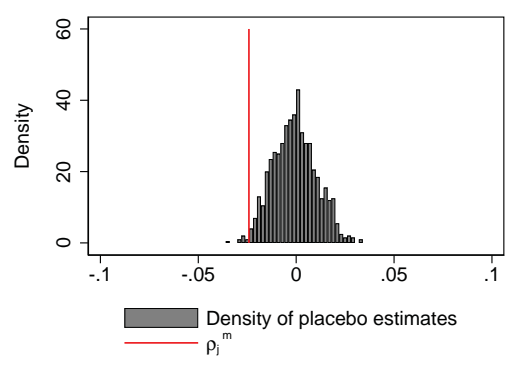

$t=6$

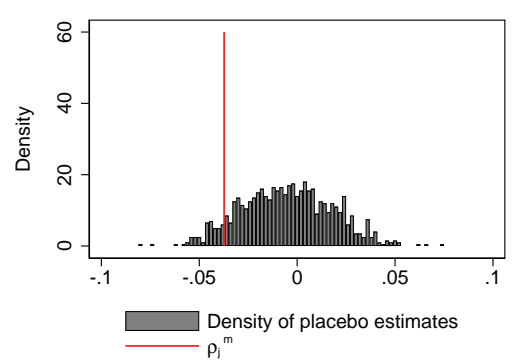

Note: Results of the placebo test where opening dates of childcare are randomly assigned to municipalities that do not have childcare for men. Based on these placebo opening dates, we replicate the analysis of the effect of childcare on earnings based on this sample. The densities are the result of 1000 random assignments of opening dates. The red lines show the actual estimates of the effect of childcare. 
Figure A.5: Child penalty of households depending on the gender of the breadwinner in the household

\section{Breadwinner earns $>50 \%$ of hh earnings}

a) Female earnings penalty

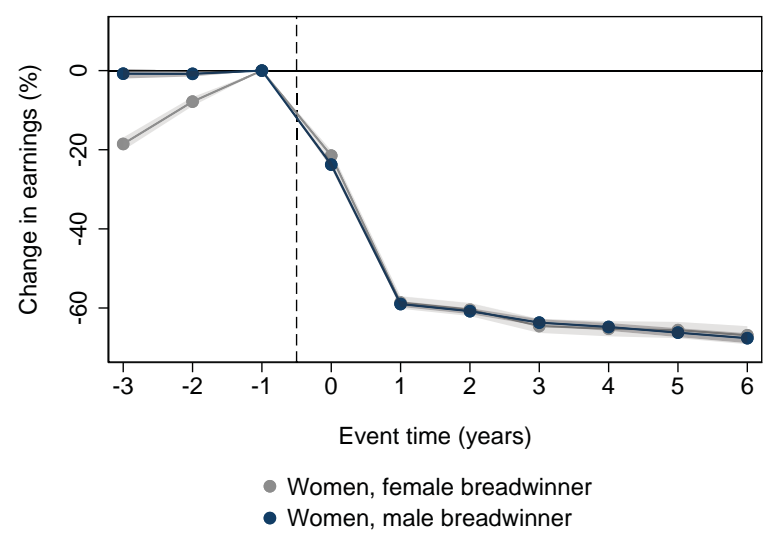

b) Male earnings penalty

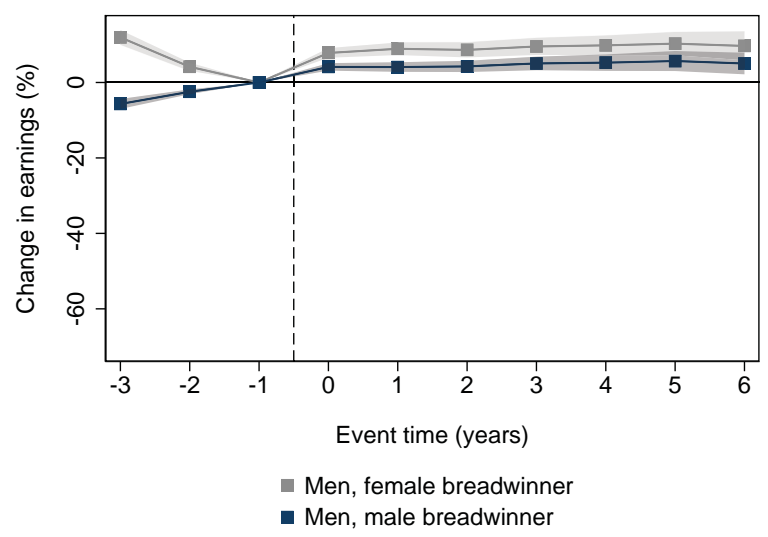

$60 \%$ of hh earnings

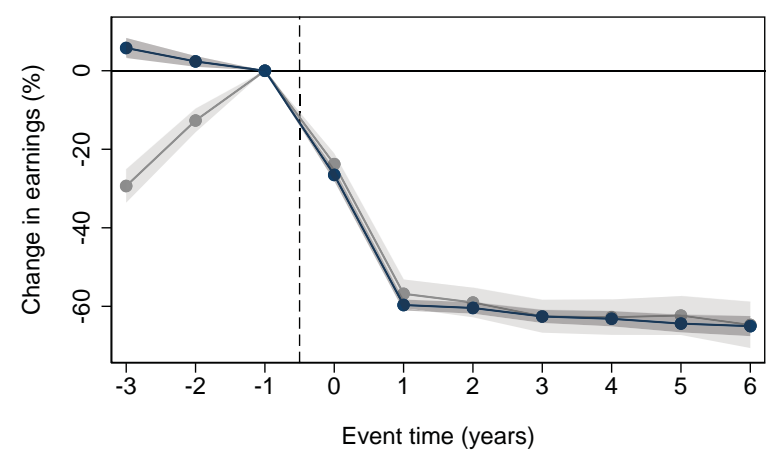

- Women, female breadwinner

- Women, male breadwinner d) Male earnings penalty

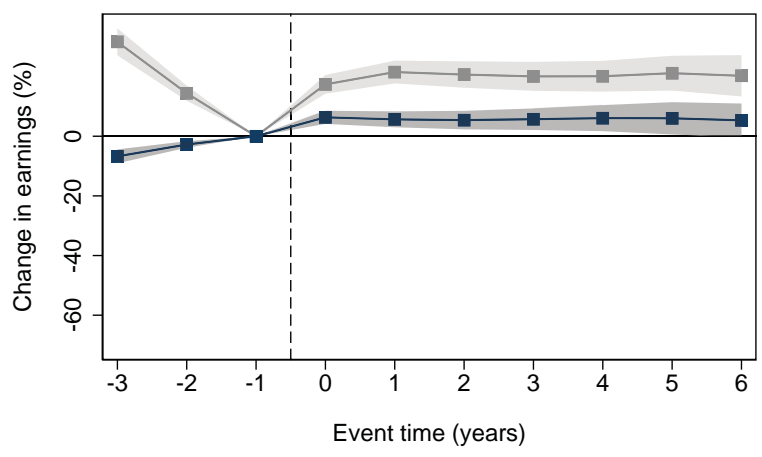

Men, female breadwinner

- Men, male breadwinner

Note: Comparison of child penalty among couples with female breadwinner and couples with male breadwinner. The panels on the left display child penalties. Panel a) displays the child penalty for women, depending on whether the man or the woman is the breadwinner (earns more) in period $t=-1$. Panel b) reports the child penalty for men and depending on who is the breadwinner in in period $t=-1$. Panels c) and $\mathrm{d}$ ) are the same as above, except that breadwinners are defined as earning at least $60 \%$ of the couple's combined earnings in $t=-1$. Note that, these estimates use all couples independent of whether they had their first child in a municipality with childcare. Confidence bounds are calculated at the 5 percent level of significance applying a non-parametric bootstrap. The corresponding estimates are displayed in Table A.12. 
Table A.12: Child penalty conditional on gender of the breadwinner in the household

\begin{tabular}{|c|c|c|c|c|}
\hline & \multicolumn{2}{|c|}{ Breadwinner $>50 \%$} & \multicolumn{2}{|c|}{ Breadwinner $>60 \%$} \\
\hline & Women & Men & Women & Men \\
\hline & $(1)$ & $(2)$ & $(3)$ & $(4)$ \\
\hline Event -3 & $\begin{array}{r}-0.008 \\
(0.006)\end{array}$ & $\begin{array}{r}-0.057^{* * *} \\
(0.007)\end{array}$ & $\begin{array}{r}0.058^{* * *} \\
(0.013)\end{array}$ & $\begin{array}{r}-0.067^{* * *} \\
(0.012)\end{array}$ \\
\hline Event -2 & $\begin{array}{r}-0.008^{* *} \\
(0.003)\end{array}$ & $\begin{array}{r}-0.025^{* * *} \\
(0.003)\end{array}$ & $\begin{array}{r}0.024^{* * *} \\
(0.007)\end{array}$ & $\begin{array}{r}-0.028^{* * *} \\
(0.006)\end{array}$ \\
\hline Event 0 & $\begin{array}{r}-0.238^{* * *} \\
(0.004)\end{array}$ & $\begin{array}{r}0.041^{* * *} \\
(0.005)\end{array}$ & $\begin{array}{r}-0.265^{* * *} \\
(0.008)\end{array}$ & $\begin{array}{r}0.063^{* * *} \\
(0.011)\end{array}$ \\
\hline Event +1 & $\begin{array}{r}-0.590^{* * *} \\
(0.004)\end{array}$ & $\begin{array}{r}0.041^{* * *} \\
(0.006)\end{array}$ & $\begin{array}{r}-0.597^{* * *} \\
(0.007)\end{array}$ & $\begin{array}{r}0.057^{* * *} \\
(0.014)\end{array}$ \\
\hline Event +2 & $\begin{array}{r}-0.608^{* * *} \\
(0.004)\end{array}$ & $\begin{array}{r}0.043^{* * *} \\
(0.008)\end{array}$ & $\begin{array}{r}-0.604^{* * *} \\
(0.007)\end{array}$ & $\begin{array}{r}0.054^{* * *} \\
(0.016)\end{array}$ \\
\hline Event +3 & $\begin{array}{r}-0.637^{* * *} \\
(0.004)\end{array}$ & $\begin{array}{r}0.050^{* * *} \\
(0.009)\end{array}$ & $\begin{array}{r}-0.626^{* * *} \\
(0.008)\end{array}$ & $\begin{array}{r}0.057^{* * *} \\
(0.018)\end{array}$ \\
\hline Event +4 & $\begin{array}{r}-0.648^{* * *} \\
(0.005)\end{array}$ & $\begin{array}{r}0.053^{* * *} \\
(0.011)\end{array}$ & $\begin{array}{r}-0.632^{* * *} \\
(0.010)\end{array}$ & $\begin{array}{r}0.061^{* * *} \\
(0.022)\end{array}$ \\
\hline Event +5 & $\begin{array}{r}-0.662^{* * *} \\
(0.006)\end{array}$ & $\begin{array}{r}0.057^{* * *} \\
(0.014)\end{array}$ & $\begin{array}{r}-0.644^{* * *} \\
(0.011)\end{array}$ & $\begin{array}{r}0.060^{* *} \\
(0.028)\end{array}$ \\
\hline Event +6 & $\begin{array}{r}-0.676^{* * *} \\
(0.006)\end{array}$ & $\begin{array}{r}0.050^{* * *} \\
(0.015)\end{array}$ & $\begin{array}{r}-0.650^{* * *} \\
(0.013)\end{array}$ & $\begin{array}{r}0.053^{*} \\
(0.029)\end{array}$ \\
\hline Event -3 . female breadwinner & $\begin{array}{r}-0.178^{* * *} \\
(0.008)\end{array}$ & $\begin{array}{r}0.177^{* * *} \\
(0.008)\end{array}$ & $\begin{array}{r}-0.351^{* * *} \\
(0.024)\end{array}$ & $\begin{array}{r}0.384^{* * *} \\
(0.019)\end{array}$ \\
\hline Event -2 . female breadwinner & $\begin{array}{r}-0.070^{* * *} \\
(0.006)\end{array}$ & $\begin{array}{r}0.066^{* * *} \\
(0.006)\end{array}$ & $\begin{array}{r}-0.151^{* * *} \\
(0.016)\end{array}$ & $\begin{array}{r}0.172^{* * *} \\
(0.013)\end{array}$ \\
\hline Event $0 \cdot$ female breadwinner & $\begin{array}{r}0.023^{* * *} \\
(0.006)\end{array}$ & $\begin{array}{r}0.037^{* * *} \\
(0.005)\end{array}$ & $\begin{array}{r}0.028^{* *} \\
(0.014)\end{array}$ & $\begin{array}{r}0.110^{* * *} \\
(0.013)\end{array}$ \\
\hline Event +1 . female breadwinner & $\begin{array}{r}0.004 \\
(0.008)\end{array}$ & $\begin{array}{r}0.048^{* * *} \\
(0.007)\end{array}$ & $\begin{array}{r}0.029 \\
(0.019)\end{array}$ & $\begin{array}{r}0.158^{* * *} \\
(0.015)\end{array}$ \\
\hline Event +2 . female breadwinner & $\begin{array}{r}0.004 \\
(0.009)\end{array}$ & $\begin{array}{r}0.044^{* * *} \\
(0.008)\end{array}$ & $\begin{array}{r}0.014 \\
(0.020)\end{array}$ & $\begin{array}{r}0.153^{* * *} \\
(0.017)\end{array}$ \\
\hline Event +3 . female breadwinner & $\begin{array}{r}-0.009 \\
(0.009)\end{array}$ & $\begin{array}{r}0.045^{* * *} \\
(0.008)\end{array}$ & $\begin{array}{r}0.000 \\
(0.022)\end{array}$ & $\begin{array}{r}0.144^{* * *} \\
(0.018)\end{array}$ \\
\hline Event $+4 \cdot$ female breadwinner & $\begin{array}{l}-0.005 \\
(0.010)\end{array}$ & $\begin{array}{r}0.046^{* * *} \\
(0.009)\end{array}$ & $\begin{array}{r}0.004 \\
(0.024)\end{array}$ & $\begin{array}{r}0.140^{* * *} \\
(0.018)\end{array}$ \\
\hline Event +5 . female breadwinner & $\begin{array}{r}0.007 \\
(0.010)\end{array}$ & $\begin{array}{r}0.046^{* * *} \\
(0.012)\end{array}$ & $\begin{array}{r}0.021 \\
(0.025)\end{array}$ & $\begin{array}{r}0.151^{* * *} \\
(0.021)\end{array}$ \\
\hline Event +6 . female breadwinner & $\begin{array}{r}0.007 \\
(0.011) \\
\end{array}$ & $\begin{array}{r}0.047^{* * * *} \\
(0.014) \\
\end{array}$ & $\begin{array}{r}0.003 \\
(0.030) \\
\end{array}$ & $\begin{array}{r}0.149^{* * *} \\
(0.025) \\
\end{array}$ \\
\hline Indiv. FE & Yes & Yes & Yes & Yes \\
\hline Year FE & Yes & Yes & Yes & Yes \\
\hline Age FE & Yes & Yes & Yes & Yes \\
\hline Married $(\mathrm{t}<0)$ & Yes & Yes & Yes & Yes \\
\hline $\mathrm{N}$ indiv. & 10355 & 10355 & 4250 & 4250 \\
\hline $\mathrm{N}$ & 112351 & 112351 & 45384 & 45384 \\
\hline
\end{tabular}

Notes: Event study estimates of female and male earnings relative to the year prior to the birth of their first child. The interaction terms with a female breadwinner dummy indicate the differential effect between couples with a female breadwinner and couples with male breadwinner in period $t-1$. The sample includes couples in all municipalities, independent of information on childcare. In columns (1) and (2), breadwinners are defined as accounting for more than $50 \%$ of a couple's earnings, whereas in columns (3) and (4), we only use couples, where the breadwinner accounts for more than $60 \%$ of combined earnings. The breadwinner is female in $22.3 \%$ of all cases in columns (1) and (2) and in $14.7 \%$ of all cases in columns (3) and (4). Standard errors are bootstrapped (1000 replications). Significance levels: ${ }^{*} \mathrm{p}<0.10,{ }^{* *} \mathrm{p}<0.05,{ }^{* * *} \mathrm{p}<0.01$. 
Download ZEW Discussion Papers from our ftp server:

http://ftp.zew.de/pub/zew-docs/dp/

or see:

https://www.ssrn.com/link/ZEW-Ctr-Euro-Econ-Research.html

https://ideas.repec.org/s/zbw/zewdip.html

$$
\text { // }
$$

IMPRINT

ZEW - Leibniz-Zentrum für Europäische Wirtschaftsforschung GmbH Mannheim

ZEW - Leibniz Centre for European

Economic Research

L 7,1 68161 Mannheim · Germany

Phone +49621 1235-01

info@zew.de·zew.de

Discussion Papers are intended to make results of ZEW research promptly available to other economists in order to encourage discussion and suggestions for revisions. The authors are solely responsible for the contents which do not necessarily represent the opinion of the ZEW. 